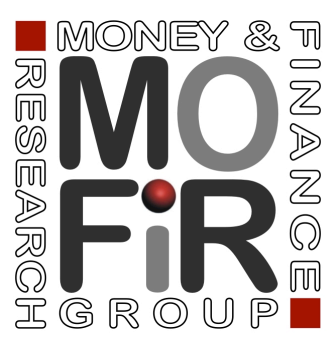

\title{
CAPITAL MARKET FINANCING AND FIRM GROWTH
}

Tatiana Didier Ross Levine

Ruth Llovet Montanes Sergio L. Schmukler

Working paper no. 166

August 2020 


\title{
Capital Market Financing and Firm Growth
}

\author{
Tatiana Didier ${ }^{a}$ \\ Ross Levine $e^{\mathrm{b}, \mathrm{c}}$ \\ Ruth Llovet Montanes ${ }^{a}$ \\ Sergio L. Schmukler, ${ }^{\mathrm{a}}$,
}

July 2020

\begin{abstract}
This paper studies whether there is a connection between finance and growth at the firm level. It employs a new dataset of 150,165 equity and bond issuances around the world, matched with income and balance sheet data for 62,653 listed firms in 65 countries over 1990-2016. Three main patterns emerge from the analyses. First, firms that choose to issue in capital markets use the funds raised to grow by enhancing their productive capabilities, increasing their tangible and intangible capital and the number of employees. Growth accelerates as firms raise funds. Second, the faster growth is more pronounced among firms that are more likely to face tighter financing constraints, namely, small, young, and high-R\&D firms. Third, capital market issuances are associated with faster growth among firms located in countries with more developed capital markets relative to banks. Capital markets are also comparatively effective at allowing financially constrained firms to raise capital.
\end{abstract}

JEL Classification Codes: F65, G10, G31, G32, L25, O10, O16, O40

Keywords: bond markets, capital market development, capital raising, equity markets, financial structure, firm dynamics, firm financing, firm size

\footnotetext{
${ }^{\mathrm{a}}$ World Bank, ${ }^{\mathrm{b}}$ University of California at Berkeley, ${ }^{\mathrm{c}}$ NBER

* We are grateful to Juan Jose Cortina, Marta Guasch, Soha Ismail, Matias Moretti, and Lucas Núñez for outstanding research assistance at different stages of the project. We received very helpful comments from Jean-Louis Arcand, Eugenia Andreasen, Fernando Broner, Paco Buera, Charlie Calomiris, Eduardo Cavallo, Julian di Giovanni, Roberto Fattal-Jaef, Tomoo Kikuchi, Edith Liu, Eswar Prasad, Luis Serven, Nirvikar Singh, and participants at presentations held at the XVII Workshop on International Economics and Finance (Costa Rica), Columbia University, Cornell University, CREIUniversitat Pompeu Fabra, the Geneva Graduate Institute, the Hong Kong Institute for Monetary Research, the Indian National Institute of Public Finance and Policy, the LACEA-LAMES Annual Meeting (Brazil), Pontificia Universidad Javeriana, Ridge Forum (Argentina), Stanford University, and the World Bank. Research support came from the World Bank Chile Research and Development Center, Knowledge for Change Program (KCP), the Latin America and the Caribbean (LAC) Region's Chief Economist Office, and the Strategic Research Program (SRP). The research presented in this paper builds on previous work that appeared as HKIMR Working Paper 17/2015, NBER Working Paper 20336, and World Bank Policy Research Paper 7353.

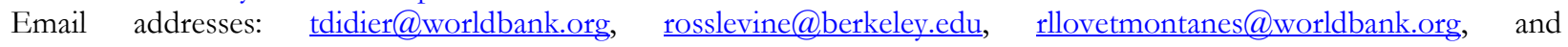
sschmukler@worldbank.org.
} 


\section{Introduction}

A large body of research finds a positive connection between capital market development and national growth rates (Levine and Zervos, 1996, 1998; Demirguc-Kunt and Maksimovic, 1998; Rajan and Zingales, 1998; Henry, 2000; Levine, 2002; Beck and Levine, 2004; Bekaert et al., 2005). This macrolevel work, however, does not necessarily imply that firms use the funds raised in these markets to increase their productive capabilities—-human capital, physical capital, and intangible capital—and grow. Firms have access to multiple sources to finance their growth, including bank credit. Moreover, capital markets can foster aggregate growth indirectly, by facilitating risk diversification, enhancing information dissemination, and boosting savings, without necessarily being the conduits of capitalaugmenting funds for corporations (Levine, 1991, 2005; Holmstrom and Tirole, 1993; Obstfeld 1994; Acemoglu and Zilibotti, 1997; Aghion et al., 2018).

To contribute to the study of capital markets and growth, we use firm-level analyses to assess the relation between firms issuing securities and changes in their productive capabilities and overall growth rates. Using firm-level data, we examine how firms that issue equity and bonds grow before, during, and after they raise new capital compared to firms that do not issue securities. We examine both overall firm growth, as measured by sales and assets, and growth in productive capabilities, as measured by human capital, physical capital, and intangible capital. Furthermore, we complement an extensive literature that suggests that the relation between securities issuances and firm growth might depend on (a) whether firms are issuing equity or bonds, (b) the severity of financing constraints on firms, and (c) the extent to which firms are issuing securities in more market-based or more bankbased financial systems. We do so by studying how the relation between issuing securities and growth varies across each of these dimensions.

To conduct the study, we assemble a comprehensive dataset of 150,165 firm-level issuances

of equities and bonds in domestic and international markets over the period 1991-2016. We match 
this transaction-level information with firm-level income statements and balance sheet data on 62,653 publicly listed firms from 65 countries. Our matched dataset includes both publicly listed firms that issued equities and bonds during our sample period and those that did not issue securities during this time period. We employ a difference-in-differences empirical strategy around capital market issuances to assess the connections between firms issuing equities and bonds, firm investment in productive capabilities, and firm growth. Our analysis controls for firm and country-year fixed effects, which capture firm time invariant characteristics and country shocks occurring at an annual frequency.

We find, first, that compared to non-issuers, firms choosing to issue securities grow faster and boost their productive capabilities (employees, tangible capital, and intangible capital). Issuers grow faster than non-issuers prior to the issuance of securities, and this growth differential significantly widens as firms issue securities. The estimates indicate that the cumulative growth differential in sales, assets, and productive capabilities for issuers relative to non-issuers around the 5-year issuance window is about 19 percentage points. Furthermore, the increase in growth rates associated with equity issuances is larger than those associated with bond issuances. These findings are consistent with the view that firms use the funds raised in securities markets to boost their productive capabilities and realize growth opportunities.

Second, we find that the relation between firm growth and securities issuances is larger among firms with tighter financing constraints, which is consistent with the view that firms issue securities to finance growth opportunities. Specifically, if firms use securities markets to finance growth, then we should observe larger changes in growth following security issuances among more financially constrained firms because the marginal returns to increasing human, tangible, and intangible capital are likely to be greater. An extensive literature mentioned below finds that smaller, younger, and more innovative firms tend to be more informationally opaque and have less tangible assets to offer as collateral. Following this literature, we use firm size, age, and R\&D (research and development) 
expenditures to proxy for financial constraints. We discover that the surge in sales, employment, and investment growth when firms issue securities is more pronounced among smaller, younger, and higher-R\&D firms. For example, in the year of issuance, the growth rate of employment is 4.62 and 6.49 percentage points faster for small and young firms than for large and old firms, respectively.

Third, we find that equity (but not bond) issuances are associated with rapid expansions of intangible investments by high-R\&D firms. This finding is consistent with research suggesting that equity issuances are the most effective way of financing increases in innovative activities and in the productive capabilities of innovative firms, because equity holders enjoy fully the upside benefits of successful innovations (Da Rin et al., 2006; Brown and Petersen, 2009; Brown and Floros, 2012; Wu and Au Yeung, 2012). Our estimations show that in the year of an equity issuance the growth of intangible assets is 3.16 percentage points higher for high-R\&D issuers than for the rest of issuers, up from 0.86 percentage points during the pre-issuance years. The analogous estimates for bond issuances are not significant.

Fourth, we find that firms issuing securities in countries with comparatively well-developed capital markets experience a larger increase in their sales and productive capabilities than their counterparts in more bank-based financial systems. This result is consistent with research stressing that market-based financial systems are comparatively effective at allowing firms that typically grow faster-smaller, younger, and innovative firms — to exploit growth opportunities (Brown et al., 2009, 2013, 2017). We also find that these firms are more prevalent in market-based economies.

Fifth, we examine how firms respond to exogenous changes in growth opportunities. One concern with the analyses thus far is that documenting growth-issuance patterns using a differencein-differences specification does not fully address endogeneity considerations. It is unclear whether changes in the supply of capital foster security issuances and firm growth, whether changes in growth opportunities encourage the issuance of securities to boost productive capabilities and realize those 
opportunities, or whether other factors are driving firm growth, issuance decisions, and capital market development. To shed light on this issue, we examine variations in the price of mining commodities and assess how firms in mining industries around the world respond in terms of issuing equities and bonds. Besides controlling for country and industry fixed effects, these analyses condition on timevarying economic and financial indicators. We find that mining firms experiencing higher commodity prices are much more likely to issue equity and bonds than other firms. These findings suggest that capital market issuances are a mechanism through which firms build productive capabilities to realize expected growth opportunities that come about at the aggregate level.

The findings in this paper contribute to questions posed by different strands of the literature, in addition to the macro-level literature linking finance and growth. First, several papers analyze how firms use the proceeds from capital market issuances. Firms can use the newly raised funds to alter their liabilities, including changing debt-equity ratios, replacing more expensive financing with cheaper funding, minimizing taxes, or changing their debt maturity (Pagano et al., 1998; De Angelo et al. 2010; Hertzel and Li, 2010; Makan and Demos, 2012; Shin and Zhao, 2013; Alden, 2014; Bass and Smith, 2018; Fan, 2019). Focusing on firm assets, other work shows that firms use the funds raised through securities issuances to accumulate cash or other financial assets, but not necessarily to directly increase human, physical, and intangible capital (Baker and Wurgler, 2002; De Angelo et al., 2010; McLean, 2011; Bruno and Shin, 2017; McLean and Zhao, 2018; Calomiris et al., 2019). Except for a couple of studies, this research tends to be silent on the use of capital markets to fund corporate investments in physical and intangible capital (Kim and Weisbach, 2008; Calomiris et al., 2020). Our study contributes to this literature by (a) examining how firms use the proceeds raised through different types of securities, namely equity and corporate bonds, (b) exploring the heterogeneity across firms facing different financing constraints, financial architectures, and growth prospects, (c) benchmarking the expansion of issuers with that of non-issuers, as it could be the case that all firms are growing and 
expanding their productive capabilities simultaneously for omitted reasons, and (d) studying changes in growth during the issuance year and afterwards relative to the pre-issuance period.

Second, extensive research suggests that smaller, younger, and more innovative firms face tighter financing constraints, creating an environment in which the returns to finance are greater among such firms. Smaller and younger firms are often more informationally opaque and generally have less collateral than larger, more established firms (Carpenter and Petersen, 2002; Beck et al., 2005; Beck and Demirguc-Kunt, 2006; Beck et al., 2008; Oliveira and Fortunato, 2006; Carreira and Silva, 2010; Hadlock and Pierce, 2010; Erel et al., 2015). ${ }^{1}$ Similarly, financial intermediaries and markets often find it difficult to evaluate novel activities and typically do not accept as collateral the types of intangible capital that compose a large part of the capital stock of innovative firms (Himmelberg and Petersen, 1994; Hall, 2002; Bougheas et al., 2003; Brown et al., 2009; Hall and Lerner, 2010; Czarnitzki and Hottenrott, 2011). ${ }^{2}$ Acquisitions can relieve financial constraints in target firms, especially when the target firm is relatively small (Erel et al., 2015), and cash inflows from fixed assets sales can boost corporate R\&D investment (Borisova and Brown, 2013). We contribute to this literature by showing that firms that are more likely to face tighter financing constraints (smaller, younger, and higher R\&D firms) grow faster than other firms when they issue securities in capital markets. This evidence is consistent with capital markets allowing firms to relax their capital constraints and realize their growth opportunities.

Third, research also suggests that the growth-issuance relation among innovative firms should depend on whether firms issue equity or debt (Brown and Petersen, 2009; Brown and Floros, 2012; Wu and Au Yeung, 2012). This work holds that equity finance is better suited for funding innovative,

\footnotetext{
1 Although publicly listed firms are subject to financial reporting and disclosure, more information is generated and analyzed for larger than for smaller firms, which affects issuance decisions (Atiase, 1985; Collins et al., 1987; Bhushan, 1989; Chang et al., 2006).

${ }^{2}$ In line with this argument, financially constrained firms benefit the most from investing in tangible assets because those assets help relax constraints, allowing for further investment (Campello and Hackbarth, 2012).
} 
riskier firms because equity holders directly benefit when the firm succeeds, and equity contracts do not accentuate problems of financial distress for firms. In contrast, debt holders are comparatively wary of these firms, as they focus less on the right-hand tail of the return distribution and more on default probabilities, collateral, and cash flows. Consistent with this view, empirical research finds that more developed equity (but not credit) markets support faster growth of innovative-intensive industries, mostly through higher productivity growth rather than fixed capital accumulation (Brown et al., 2013, 2017; Hsu et al., 2014). Industry-level studies, however, do not necessarily document a direct link between issuing securities and boosting productive capabilities. Moreover, existing work focuses on equity versus credit, not on the issuance of bonds. We show that the relation between securities issuances and the growth of productive capabilities, especially intangible capital, is more pronounced among innovative firms issuing equity rather than bonds.

Fourth, we build on several strands of the literature suggesting that financial architecture (the comparative development of capital markets and banks) plays a role in the finance-growth nexus. ${ }^{3}$ The emerging literature on financial development, innovation, and technology-led growth implies that countries with market-based financial systems should be better positioned than their bank-based counterparts to finance innovative activity, particularly for smaller and younger firms more dependent on external finance (Brown et al., 2009, 2013, 2017). The evidence in these studies suggests that financial architecture might play a role on the type of firms that obtain financing, thereby affecting the

\footnotetext{
${ }^{3}$ A large literature at the aggregate macro level is inconclusive regarding the effects of financial architecture in promoting economic growth. On the one hand, early empirical research argues that it is the overall level of financial development that matters for economic success, but not financial structure per se (Arestis et al., 2001; Beck and Levine, 2002; DemirgucKunt and Maksimovic, 2002; Levine, 2002; Demirguc-Kunt and Levine, 2004; Levine, 2005; Ndikumana, 2005; Chakraborty and Ray, 2006; Popov, 2018). On the other hand, other studies suggest non-linearities in this relation: the effects of a country's financial structure on economic growth depend on its level of economic development (Boyd and Smith, 1998; Levine, 2002; Tadesse, 2002; Cihak and Demirguc-Kunt, 2012; Demirguc-Kunt et al., 2013; Luintel et al., 2016; Seven and Yetkiner, 2016). Related research studies why firms cross-list their securities in international markets and the evolution of capital structure around those events (Karolyi, 2006; Claessens and Schmukler, 2007; Gozzi et al., 2008, 2010).
} 
country's composition of firms. These potential differences in firm composition could be accompanied by significant differences across countries in the magnitude of the direct financing channel explored in this paper. ${ }^{4}$ Consistent with the arguments in the literature, we show that countries with more developed capital markets witness a different mix of listed firms (smaller, younger, and more innovative), and that firms grow faster in those countries when issuing securities relative to firms in countries with more developed banking systems.

Fifth, as a way to understand how exogenous factors can affect firm financing, researchers have analyzed how changes in international commodity prices affect (a) financing through the banking sector (Agarwal et al., 2017, 2020) and (b) aggregate investment and business cycles (Caputo and Irarrazabal, 2017; Fernández et al., 2017; Drechsel and Tenreyro, 2018; Valdes, 2018). We expand on this literature by studying how changes in prices in the mining industry, as a proxy for exogenous shocks to the value of production, can lead firms to also issue securities in capital markets. Our findings suggest that at least part of the relation between finance and growth might be driven by opportunities that arise at the industry level, beyond idiosyncratic shocks to firm growth opportunities, which are very difficult to observe for the econometrician. Firms seem to realize those aggregate opportunities by tapping financing in capital markets, which could explain some of the aggregate effects on investment documented in the literature. This type of micro-level evidence also complements a large literature that argues that shocks to the financial side that lower the cost of capital also prompt firms to raise capital.

The remainder of the paper is organized as follows. Section 2 describes the data. Section 3 describes the findings on the relation between capital market financing and firm performance around issuance activity. Section 4 shows the heterogeneity of the results across firms. Section 5 describes the

\footnotetext{
4 A related line of research argues that firms in civil law (bank-based) countries typically rely less on equity markets to finance their investments than firms in common law (market-based) countries (La Porta et al., 1997), although firms in both sets of countries use equity issuances to finance capital expenditures and R\&D (Kim and Weisbach, 2008).
} 
heterogeneity across countries. Section 6 explores the role of exogeneous growth opportunities in the likelihood of firms to issue securities in capital markets. Section 7 concludes.

\section{Data}

\subsection{Data construction}

The data on firm capital raising activity cover the period 1991-2016 and come from the Refinitiv's Security Data Corporation (SDC) Platinum database. This database provides transaction-level information on new capital raising issuances of common and preferred equity and publicly and privately placed bonds in capital markets around the world. ${ }^{5}$ Given that the SDC Platinum database does not collect data on debt issuances with maturities shorter than one year, the dataset does not cover commercial paper.

To examine the comparative performance of issuing and non-issuing firms, we combine the data on equity and bond issuances with data on income and balance sheets for publicly listed companies from the Worldscope database. We match equity and corporate bond issuance data with firm income and balance sheet data using the CUSIP identifier. If the matching proves unsuccessful, we use the following identifiers: SEDOL, ISIN, and Thomson Reuters Permanent Identifier. ${ }^{6}$ For the majority of countries in our matched sample, we have both capital market issuance and income and balance sheet data on at least 70 percent of the listed firms in each country, where data on the total number of listed firms per country come from the World Federation of Exchanges database.

Worldscope provides data at the consolidated level for listed companies with subsidiaries. For those parent companies, we aggregate the issuance activity of the parent and the related (listed and

\footnotetext{
${ }^{5}$ SDC Platinum collects data on capital raising issuance mostly from filings with local regulatory agencies and stock exchanges, complementing this information with data from other sources such as offering circulars, prospectuses, surveys of investment banks, brokers, and other financial advisors, news sources, trade publications, and wires.

${ }^{6}$ This matching algorithm allows us to match 87 percent of the equity issuances and 70 percent of the corporate bond issuances reported in SDC Platinum.
} 
non-listed) subsidiaries to make issuance data consistent with the level of aggregation of the income and balance sheet data. Listed subsidiaries with income and balance sheet data are considered as separate firms with their own matching issuance activity. Our final sample includes separately both listed parent firms and listed subsidiaries, in addition to the many other firms that are not part of conglomerates. To make sure that our results are not affected by the inclusion of parent firms, we repeated the analysis by excluding parent firms that have subsidiaries with issuance activity in capital markets over the 1991-2016 period. Our main findings are robust to this change, implying that firm performance around issuance is not driven by the capital raised through subsidiaries. This is not surprising because the number of issuances through subsidiaries is 14,725 (less than 10 percent of the total) and the number of firms with issuing subsidiaries is 4,232 (less than 7 percent of the total).

We exclude all firms with a primary industry classification in the financial sector (SIC codes 6000-6999) or the public sector (SIC codes 9100-9999). Moreover, we exclude both countries with less than 10 firms issuing in capital markets between 1991 and 2016 as well as offshore financial centers. $^{7}$ Firm-level attributes (total assets, sales, tangible fixed assets, intangible assets, and R\&D expenditures) are all measured in logs in constant 2011 U.S. dollars (except for the number of employees, which is just measured in logs). Their growth rates are thus calculated as the difference in logs. All data on firm-level attributes are winsorized by country at the 1 percent level.

Our final matched dataset comprises 62,653 firms from 65 countries, of which 45,306 issued equity and/or bonds at least once during the sample period (Appendix Table 1). We examine 150,165 issuance events: 102,161 equity issuances, 38,487 corporate bond issuances, and 9,517 mixed issuances (when a firm issues equity and bonds in the same year). We keep the 17,347 publicly listed firms that did not issue as part of the control group in the analyses. By excluding unlisted firms, the sample leaves

\footnotetext{
${ }^{7}$ The list of offshore centers is based on the IMF report "Offshore Financial Centers (OFCs): IMF Staff Assessments."
} 
out firms that are (a) relatively small and sometimes informal and (b) likely to have different accounting standards.

For the analysis on country heterogeneity in Section 5, we use country-level data on economic, bank, and capital market development from the World Development Indicators database and the Financial Structure and Development database. Economic development is measured using gross domestic product (GDP) per capita in constant 2011 U.S. dollars. Bank development is the ratio of private credit by deposit money banks to GDP. Capital market development is measured as the sum of equity and corporate bond market capitalization to GDP. For the analysis on growth opportunities in Section 6, we use industry-level and country-level data. Appendix Table 2 lists the different variables and sources used for Sections 5 and 6.

The results reported throughout this paper are robust to a number of alternative sampling approaches. First, the results hold: (a) when excluding China or the United States, which together account for about 40 percent of world GDP; or (b) when simultaneously excluding Canada, Japan, and the United Kingdom, which together account for the largest number of issuers-23 percent of the total number of capital market issuers in the sample. Second, our findings are robust to (a) excluding utility companies (SIC codes 4900-4999) or (b) examining only manufacturing firms. Third, our findings also hold when excluding initial public offerings (IPOs), indicating that firms going public do not drive the results. Fourth, we observe a statistically significant increase in firm growth and investments in the year of issuance after excluding the years in which firms were acquirers in merger and acquisition (M\&A) deals. This suggests that firms' expansion comes from their own internal growth, in addition to any growth generated by the M\&A activity. To conduct this last test and identify acquirer firms, we use the variable Net Assets from Acquisitions from Worldscope. This variable represents assets acquired through pooling of interests or mergers. About 52 percent of the firms in the sample (32,629 firms) conducted an M\&A transaction. 


\subsection{Stylized facts on capital market growth and the comparative performance of issuing firms}

We first document three key patterns in the data before conducting more rigorous empirical analyses in Section 3. To illustrate these patterns, we compare the beginning and end of the sample period to show how capital markets and issuance activity have changed over time and to describe how issuance and growth might be related. In later sections, we conduct these evaluations on a yearly basis rather than simply focusing on changes between these two points in time.

First, capital markets have grown markedly since the early 1990s and have become a sizeable source of corporate financing both in developing and high-income countries. ${ }^{8}$ For the median country in the sample, equity and corporate bond market capitalization expanded from an average of 66 percent of GDP over the 1991-95 period to an average of 101 percent of GDP during the 2011-16 period (Figure 1). The market capitalization of equity and bonds is comparable to the stock of bank loans, which totaled about 98 percent of GDP in the median country during the 2011-16 period. Equity markets are on average double the size of corporate bond markets, and account for an even large proportion of capital markets in developing countries, where corporate bond markets are relatively underdeveloped. Security issuances have also grown materially. The per annum value of new issuances as a percentage of GDP for the median country rose from about 3.7 percent during the 1991-95 period to 6.3 percent during the 2011-16 period. Thus, whether considering market size or primary market activity, capital markets grew substantially in the median country relative to GDP.

Second, capital markets have expanded not only as measured by the aggregate size of markets and value of issuance activity. The number of firms raising capital through equity or bond issuances also increased, from 15,436 to 25,126 between the periods 1991-99 and 2009-16 (Table 1, Panel A).

\footnotetext{
${ }^{8}$ We classify countries into developing and high-income following the World Bank classification of countries. High-income countries are those with a gross national income (GNI) per capita in 2016 above US $\$ 12,235$. All other countries are classified as developing countries.
} 
Firms actively use these markets to obtain financing. On average, firms raise capital between two and three times per decade, with the average issuance accounting for 19 percent of a firm's total assets.

Third, firms that raise funds in capital markets tend to grow at a faster pace than non-issuing listed firms, and at a faster pace than GDP (Table 1, Panel B). Over the period 2009-16, the median firm raising capital through equities or bonds grew 4.3 percentage points faster in terms of assets than the median non-issuing firm in that period. This growth differential is consistently positive over time and across different measures of firm performance. For example, over the same period, the annual growth rate of employment by issuing firms was 2.8 percent, whereas it was 0.2 percent in the case of non-issuing firms. As comparison, the average growth rate over time of the median listed firm in the median country is similar to the average GDP growth rate of the median country. For example, for the median listed firm the average growth of sales was 2.8 percent over the period 1991-99, 11.7 percent over 2000-07, and 0.4 percent over 2009-16. This is similar to the average GDP growth rate for the median country, which was 2.4 percent, 8.3 percent, and 0.5 percent, respectively, over the same periods.

\section{Capital Market Financing and Firm Performance}

To assess the difference in performance between issuing and non-issuing firms, we employ an event study approach, where the dependent variable is a measure of firm growth around a five-year issuance window. We use a difference-in-differences regression strategy that evaluates the growth of issuing and non-issuing firms before, during, and after issuances. We focus on five measures of firm growth: the growth rate of total assets, sales, tangible fixed assets (PPE), intangible assets, and the number of employees. Whereas total assets will increase after a firm issues securities if the firm accumulates cash or other financial assets, increases in tangible fixed assets, intangible assets, and employees typically involve improvements in the productive capabilities of the business. To allow for potential differences 
across financing instruments, we separately analyze (a) the union of all equity and bond issuances (referred to as capital market issuances from now on), (b) equity issuances only, and (c) bond issuances only.

The regression equation is as follows:

$$
\text { Growth }_{i s c t}=\gamma_{0}+\gamma_{1} \text { PreIss }_{i s c t}+\gamma_{2} \text { Issuance }_{i s c t}+\gamma_{3} \text { PostIss }_{i s c t}+\delta_{i}+\omega_{c t}+\varepsilon_{i s c t},
$$

where Growth $h_{\text {isct }}$ is the growth rate of firm $i$, in industry $s$, in country $c$, during year $t$. The window around issuance is captured by (a) an issuance dummy that equals one in the year of issuance and zero

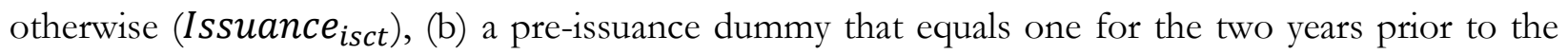
issuance and zero otherwise $\left(\right.$ PreIss $\left._{i s c t}\right)$, and (c) a post-issuance dummy that equals one for the two

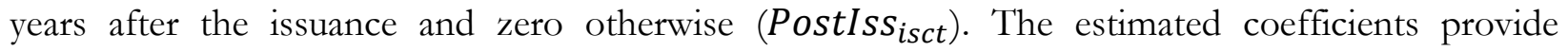
information on the average growth rate of firms during the pre-issuance, issuance, and post-issuance years relative to the growth rate during the years outside the issuance window. Namely, the estimated coefficients show the growth rate differential around the issuance years vis-à-vis the growth rate of all the firms in the sample during their non-issuance years. We control for firm $\left(\delta_{i}\right)$ and country-year fixed effects $\left(\omega_{c t}\right)$ to account for possible heterogeneity across firms and for factors that affect countries over time. We report standard errors clustered at the country level, but the results are robust to clustering at either the firm level or the country-year level.

The estimates for capital market issuances show that issuing firms typically grow significantly faster than non-issuing firms before, during, and after the issuance of securities (Table 2, Panel A). This growth differential significantly widens during the issuance year, as indicated by the two-tailed Wald tests between the coefficients of the issuance and pre-issuance dummies. For instance, total assets of issuing firms grow, on average, 19.26 percentage points faster than those of non-issuing firms in the year of issuance, up from 5.45 percentage points during the pre-issuance years. The predicted 
growth differential in total assets in the year of issuance is approximately 2.6 times faster than the growth rate of the average firm in the sample.

The faster expansion of firms' assets around the time of issuance implies that the funds raised from securities are not simply used to rebalance firms' financial accounts. Some researchers argue that firms could raise capital to pay off liabilities (debt retirement), replace more expensive financing with cheaper funding, minimize taxes, or change the duration of debt (Pagano et al., 1998; Makan and Demos, 2012; Alden, 2014; Bass and Smith, 2018; Fan, 2019). However, our evidence shows that they are also used for firms' expansion. These findings on assets, however, do not show whether there is a material increase in productive capabilities, as firms can also use the funds to accumulate cash and make financial investments, acting themselves as financial intermediaries (Baker and Wurgler, 2002; De Angelo et al., 2010; McLean, 2011; Bruno and Shin, 2017; McLean and Zhao, 2018). ${ }^{9}$ Thus, the estimates of the regressions on tangible fixed assets, intangible assets, and employment are of special interest.

As in the case of total assets, the growth of tangible fixed assets, intangible assets, and employment is larger for issuing firms than for non-issuing firms during the entire five-year issuance window. This growth differential accelerates significantly during the issuance year. For example, during the issuance year, the growth rates of employment, tangible and intangible assets are, respectively, 5.94, 10.55, and 11.55 percentage points faster for issuing firms than for non-issuing ones. These results are consistent with the view that firms use the funds raised in capital markets to increase productive capabilities. For sales, the results in Table 2 also show that growth is faster among

\footnotetext{
9 The literature identifies three main motives for firms' cash accumulation: (a) precautionary savings while funding conditions are good, (b) market timing to benefit from equity overvaluation, and (c) carry-trade to benefit from highinterest rate differentials between domestic and foreign currencies.
} 
issuing firms than among non-issuing ones during the entire issuance window, though growth does not accelerate in the year of issuance. ${ }^{10}$

Cumulatively, the positive growth differential between issuers and non-issuers is larger than the one implied by each regression coefficient separately, and it translates into large differentials over time (Figure 2). ${ }^{11}$ For example, assuming that issuers and non-issuers are ex ante equal in terms of size, the former would become 18.97 percent larger than the latter, as measured by the number of employees at the end of the 5 -year issuance window. ${ }^{12}$ This cumulative growth differential is even larger if we take into account that issuing firms tend to issue more than once during their lifetime (Table 1). For the 1991-2016 period, considering that the median firm issues about two times per decade and that employment at non-issuing firms grows on average at 0.97 percent per annum, the estimates predict that employment at issuing firms would grow at about 4.5 percent per annum. This would imply a cumulative size differential of 136 percent at the end of the sample period.

Although both equity and bond issuers tend to grow faster than non-issuers, the growth differential is larger for equity issuers. For example, during the year of issuance, equity issuers grow on average 6.62 percentage points faster as measured by employees than non-issuers, whereas this differential is about 3.55 percentage points for bond issuers (Table 2, Panels B and C). ${ }^{13}$ Equity issuers grow faster than bond issuers even though equity issuances tend to be smaller. The median equity

\footnotetext{
${ }^{10}$ The only exception to this pattern of positive growth differentials for issuers relative to non-issuers involves asset growth during the post-issuance period, where we find a negative growth differential. This result is consistent with changes in firms' cash holdings. In the year that firms raise capital, they keep a substantial fraction of the new funds as cash. This fraction decreases as cash is used for other expenditures, including new employees and operating expenses.

${ }^{11}$ Even if the relative growth of issuers vis-à-vis non-issuers declines in the post-issuance period, it does not undo the growth achieved in the pre-issuance and issuance years. For example, in the case of assets, for which the post-issuance coefficient is negative, issuing firms still accumulate a growth differential of 24.97 percentage points vis-à-vis non-issuing firms at the end of the 5-year issuance window (Figure 2).

${ }^{12}$ The cumulative size differential is equivalent to the cumulative growth differential as we normalize the ex ante size of both issuers and non-issuers to one, and we assume zero growth for non-issuers. That is, for the purpose of Figure 2, we do not take into account the coefficients on the fixed effects. However, qualitatively similar estimates would be obtained if we assumed a positive growth rate for non-issuers.

${ }^{13}$ Still, both coefficients are large in economics terms. The estimated growth differential is 148 percent and 75 percent of the average firm growth in the sample for equity and bond issuers, respectively.
} 
issuer raises about US $\$ 20.55$ million per issuance, whereas the median bond issuer raises US $\$ 77.91$ million per issuance. These results are consistent with an extensive body of research that finds that high-growth and riskier firms are more likely to issue equity than debt due to the nature of equity contracts (Jensen and Meckling, 1976; Myers, 1977; Marsh, 1982; Rajan and Zingales, 1995; Fluck, 1998; Gul, 1999; Bolton and Freixas, 2000; Barclay et al., 2003; Hosono, 2003; Johnson, 2003; Hovakimian et al., 2004; Billett et al., 2007; Gatchev et al., 2009; Wu and Au Yeung, 2012).

To address possible concerns that these findings on the growth differential between issuing and non-issuing firms are driven by one or a few industries, we separately examine the major industry categories. The growth differential patterns hold across each industry (Table 3): issuing firms tend to grow faster than non-issuing firms and part of the funds raised from issuances are used to increase firms' productive capabilities as measured by employees, tangible fixed assets, and intangible assets. These findings suggest that the results are not driven by any specific industry.

An additional concern is that the large growth differential between issuing and non-issuing firms might be related to the type of firms included in the control group, which comprises listed firms that did not issue during the period 1991-2016. These firms might be slow growing and completely disengaged from capital markets. To address this concern, we restrict the sample to firms that issued equity or bonds at least once during this period. Thus, these difference-in-differences estimations contrast the growth of firms around the issuance activity vis-à-vis the growth of firms when they are not issuing securities, excluding firms that never issued during our sample period. The core results of the paper hold when using this alternative sample (Appendix Table 3).

\section{Firm Heterogeneity}

In this section, we examine whether the growth differentials between issuing and non-issuing firms are more pronounced among firms that are more likely to face tighter financing constraints. To the 
extent that firms lack access to non-capital market sources of financing, the growth differential between issuing and non-issuing firms would likely be larger because there are fewer alternatives to relieving financing constraints. Similarly, to the extent that financing constraints prevented firms from exploiting growth opportunities, relaxing these constraints through the issuances of stocks or bonds would likely be associated with larger increases in investments than if those firms faced less restrictive financing constraints prior to issuing securities.

We consider three proxies for the severity of firm financing constraints: firm size, age, and R\&D intensity. We follow the literature that argues that relatively small, young, and innovative firms are more prone to underinvestment due to financing frictions. These firms tend to be more informationally opaque and riskier, and tend to have less tangible assets to offer as collateral. We measure firm size with the log of assets, firm age with the number of years since its establishment, and firm $R \& D$ intensity with the $\log$ of the ratio of $R \& D$ expenditures to total investment (the sum of capital expenditures and R\&D expenditures).

\subsection{An Illustration of Growth Differentials by Size, Age, and RळD Intensity}

We begin the analyses by estimating how the growth differentials between issuing and non-issuing firms vary with firm size, age, and R\&D intensity. We do this by estimating the specification described in Section 3 with quantile regressions. As earlier, we regress firm growth on three issuance-window dummy variables (pre-, during, and post-issuance). However, we now estimate one regression for each decile of the firm size, age, and R\&D intensity distributions. Firms are classified according to their median value in each variable over the period 1991-2016. We illustrate the results from these quantile regressions in Figure 3, focusing on the estimates for the growth in assets in the year of issuance. Along the vertical axis, we plot the estimated growth differential between issuing and non-issuing firms and provide the 95 percent confidence interval around each estimate. We do this for each decile 
of the firm size distribution in Panel A, each decile of the firm age distribution in Panel B, and each decile of the firm R\&D intensity distribution in Panel C. In this way, we illustrate how the growth gap between issuing and non-issuing firms varies by each firm characteristic.

The results from the quantile regressions indicate that security issuances are associated with greater accelerations in firm growth among smaller, younger, and higher-R\&D firms (Figure 3). For example, issuing firms at the bottom decile of the size distribution (small firms) grow, on average, 48 percentage points faster than non-issuing firms in terms of assets, whereas this growth differential is about 6 percentage points for firms at the top decile. Still, the growth differential at the top decile is economically significant, being 37 percent larger than the average GDP growth (of 4.39 percent) across countries in the sample for the 1991-2016 period. When classified according to the degree of $\mathrm{R} \& \mathrm{D}$ intensity, issuing firms at the top 10 percent of the $\mathrm{R} \& \mathrm{D}$ intensity distribution (high- $\mathrm{R} \& \mathrm{D}$ firms) grow 28.2 percentage points faster in terms of assets than those at the bottom 10 percent. These results hold not only when comparing firms at the extremes of the distribution, but also when observing the entire distribution. That is, the growth differential between issuers and non-issuers monotonically declines along the deciles of the firm size and age distributions, and monotonically increases along the R\&D intensity distribution. Qualitatively similar patterns, although not strictly monotonic, are obtained when measuring firm growth in sales, number of employees, tangible fixed assets, and intangible assets (Appendix Figure 1).

In Sections 4.2. and 4.3., we complement this analysis by examining differences across financing instruments (equity versus bonds). In addition, we formally test whether the heterogeneity across firm size, age, and $\mathrm{R} \& \mathrm{D}$ intensity is statistically significant and economically relevant, considering the entire issuance window (including the pre- and post- issuance years). To do so, we pool all observations and estimate a simpler regression specification based on categorical variables. 


\subsection{Firm Size and Firm Age}

We now examine the comparative growth performance of issuing and non-issuing firms, while differentiating them by size and age. The fact that smaller and younger firms are often more informationally opaque, have a shorter history, and generally have less collateral than larger, more established firms aggravate financial frictions, and thus make it more difficult for them to access external finance at reasonably favorable terms. This makes their investments and growth more dependent on the availability of internally generated funds. ${ }^{14}$ To the extent that smaller and younger firms face more binding financing constraints prior to issuing securities, we expect that relaxing those constraints through securities issuances will be associated with a greater surge in investment and growth among these types of firms. We test this view by including a dummy for small (young) firms in our baseline regression, as well as its interaction with the pre-, during, and post-issuance dummy variables. This leads to the following empirical specification:

$$
\begin{aligned}
\text { Growth }_{\text {isct }}= & \gamma_{0}+\gamma_{1} \text { PreIss }_{i s c t}+\gamma_{2} \text { Issuance }_{i s c t}+\gamma_{3} \text { PostIs }_{i s c t}+\gamma_{4} \text { Small }_{i s c t} \\
& +\gamma_{5}\left(\text { PreIss }_{i s c t} * \text { Small }_{i s c t}\right)+\gamma_{6}\left(\text { Issuance }_{i s c t} * \text { Small }_{i s c t}\right) \\
& +\gamma_{7}\left(\text { PostIss }_{i s c t} * \text { Small }_{i s c t}\right)+\delta_{i}+\omega_{c t}+\varepsilon_{i s c t},
\end{aligned}
$$

where the coefficients on the interaction terms tell us how the differential growth between issuers and non-issuers compares between small (young) and large (old) firms. We estimate separate regressions for firm size (including the small dummy) and age (including the young dummy), although we also test how the results change when both firm size and age are included in the same regression specification.

We consider several empirical definitions of a "small" firm. One method is to define firms as large or small based on the median value of assets across firms in a particular country and year (50

\footnotetext{
14 Several papers find that smaller and younger firms display higher investment-cash flow sensitivities than larger and more mature firms (Fazzari et al., 1988; Gilchrist and Himmelberg, 1995; Oliveira and Fortunato, 2006; Carpenter and Guariglia, 2008; Mulier et al., 2016). Other studies argue that financial constraints are captured by a firm's propensity to save cash out of cash flows, the so-called cash flow sensitivity of cash (Almeida et al., 2004).
} 
percent threshold). A second method is to define a broader selection of firms as small given that the size distribution of firms is highly skewed. Thus, we define small as the bottom 75 percent of all sampled firms in a given country and year (75 percent threshold). Following the methodology in Calomiris et al. (2020), these two methods use country-year distributions to classify firms as large or small because a firm that is comparatively large in one country might be comparatively small in another. ${ }^{15}$ We also use alternative methods that examine all firms in the sample, rather than using these country-year benchmarking samples. All of the methods yield qualitatively similar results. We report the findings using the definition of "small" as firms at the bottom 75 percent of sampled firms in each country and year.

For firm age, we consider three alternative measures. The first two measures are discrete, defining a firm as "young" if it has been alive for less than 15 or 10 years respectively. The third measure is a continuous variable age, which equals the number of years since the firm was established. Again, the results are qualitatively similar when using the different definitions of young firms. We report the results using the definition of young as firms that have been alive for less than 15 years. Both the small and young dummies vary within firms over time.

The estimations show that capital market issuances are associated with faster growth among smaller and younger firms than among their larger and older counterparts (Tables 4 and 5). Moreover, these growth differences are especially pronounced when focusing on equity market issuances. For example, in the year of issuance, the growth rate of employment is 4.62 (6.49) percentage points faster for small (young) issuing firms than for large (old) issuing firms, which in turn grow 3.17 (3.12) percentage points faster than non-issuing firms. These growth differences between small and large issuing firms, and between young and old issuing firms, are economically large, as the average growth

\footnotetext{
${ }^{15}$ For example, the median listed firm in China has US\$242.66 million in assets, whereas the median listed firm in Vietnam has US $\$ 17.01$ million in assets. Therefore, a firm that has US\$100 million in assets is considered large in Vietnam, whereas it is small in China.
} 
rate of firm employment in the overall sample is about 4.48 percent per annum. Furthermore, despite the positive correlation between firm size and age, the findings hold when both dimensions are simultaneously considered in the estimations (Table 6). That is, capital market issuances are associated with faster growth among both small and young firms.

Overall, we find a marked acceleration of firm growth around issuances in the groups of firms that are expected to be especially sensitive to capital market financing. Even within the universe of publicly listed firms, for which the financing constraint problems should be somehow attenuated, we still find economically and statistically significant heterogeneity based on firm size and age.

\subsection{High-R\&D Industry}

We next evaluate the comparative growth performance of issuing and non-issuing firms, while differentiating by their R\&D intensity. High-R\&D firms have a larger proportion of intangible assets relative to tangible assets. Intangible assets, however, are perceived as less valuable forms of collateral because they are more difficult to value, less liquid, and riskier than tangible assets. Hence, they are often less suitable in easing firms' credit constraints. Moreover, innovative firms tend to use cuttingedge technologies to develop new products and processes, which are generally riskier and more difficult to evaluate and monitor, accentuating asymmetric information problems. To the extent that high-R\&D firms face more stringent financing constraints because of their novel activities and their higher proportion of intangible assets, we expect that security issuances will be associated with a greater surge in investments and growth among high-R\&D firms.

Furthermore, research suggests that equity is more effective than debt for funding innovativeintensive activities, firms, and industries. Equity contracts do not require collateral and do not aggravate firms' problems of financial distress. Moreover, equity holders directly benefit when the firm succeeds. In contrast, debt holders are comparatively wary of high-R\&D firms, as they focus less 
on the right-hand tail of the return distribution and more on default probabilities, collateral, and cash flows. Consequently, firms might use bank or bond financing to fund tangible investments, such as PPE, and equity financing to fund intangible investments. The distinction between equity and bond financing is thus particularly important when analyzing the performance of high-R\&D firms around capital market issuances. Because of the innovative nature of these firms and their higher dependence on intangible assets, we hypothesize that high-R\&D firms would observe relatively higher growth rates around equity issuances than other issuing firms.

To study how high-R\&D firms perform around episodes of capital market financing, we extend our baseline specification (Equation 1) and include a high-R\&D dummy interacted with the pre-, during, and post-issuance dummies. The estimation results are reported in Table 7. Specifically, for each of the five measures of firm growth, we estimate:

$$
\begin{aligned}
& \text { Growth }_{i s c t}=\gamma_{0}+\gamma_{1} \text { PreIss }_{i s c t}+\gamma_{2} \text { Issuance }_{i s c t}+\gamma_{3} \text { PostIss }_{i s c t}+\gamma_{4}{\text { HighR } \& D_{s}} \\
& +\gamma_{5}\left(\text { PreIss }_{i s c t} * H i g h R \& D_{s}\right)+\gamma_{6}\left(\text { Issuance }_{i s c t} * H i g h R \& D_{s}\right) \\
& +\gamma_{7}\left(\text { PostIss }_{i s c t} * H i g h R \& D_{s}\right)+\delta_{i}+\omega_{c t}+\varepsilon_{i s c t},
\end{aligned}
$$

where $\operatorname{HighR} \& D_{s}$ is a dummy that equals one if the firm is in a high-R\&D industry and zero otherwise.

To compute the industry-level R\&D intensity, we follow the literature and use the United States as a benchmark. ${ }^{16}$ This approach assumes that publicly listed U.S. firms face relatively frictionless capital markets and, thus, their $R \& D$ investment is primarily driven by technological demand (Rajan and Zingales, 1998). Specifically, we obtain the ratio of R\&D expenditures to total investments for the median firm in the United States within each 2-digit SIC industry over the period

\footnotetext{
16 We conduct several robustness tests using a number of alternative samples and measures of R\&D intensity. Notably, we obtain similar results to those reported in Table 7 if we: (a) use the continuous version of the high-R\&D dummy (based on U.S. data), (b) exclude the U.S. from the sample, and (c) restrict the sample to the manufacturing industry, defining high-R\&D industries as those with a SIC code in the groups 28, 35, 36, and 38.
} 
1991-2016 (Brown et al., 2017). If this ratio is above 0.6 for a given industry, the industry is classified as high-R\&D. ${ }^{17}$ This industry classification for the United States is then applied to all other countries. This classification does not vary either across countries or over time. Moreover, it yields marked differences in the asset composition across high- and low-R\&D firms in the sample. For example, the ratio of intangible to tangible assets is 0.62 for the median high-R\&D firm in the average country, whereas it is 0.09 for the median non-high-R\&D firm.

Consistent with the arguments presented above, the estimates show that: (a) equity issuances are associated with faster growth among high-R\&D issuing firms than among other issuing firms; and (b) equity issuances have an especially strong, positive link with intangible investments by high-R\&D firms. As predicted, these patterns hold for equity financing but not for bond financing (Table 7, Panels B and C). As an example of the first finding, in the year of an equity issuance, the growth rate of employment is 2.45 percentage points faster for high-R\&D firms than other issuing firms. On the second finding, our results indicate that intangible investment is, in fact, more responsive to equity issuances than is investment in fixed capital. In the year of an equity issuance, the growth of intangible assets is 3.16 percentage points higher for high-R\&D issuers than for the rest of issuers, and this differential increases to 4.35 percentage points during the post-issuance years (Table 7, Panel B). ${ }^{18}$ In contrast, the interaction term for tangible fixed assets is not significant in the year of issuance and is quantitatively small in the post-issuance period.

The rapid expansion of intangible assets by high-R\&D firms following equity issuances is not reflected in an immediate increase in sales. This result is consistent with the view that, relative to fixed

\footnotetext{
17 This threshold corresponds to the industry at the $75^{\text {th }}$ percentile of the R\&D intensity distribution for the U.S. Based on this classification, high-R\&D industries correspond to two-digit SICs 28 (chemical and allied products), 35 (industrial machinery and equipment), 36 (electronic and other electric equipment), 38 (instruments and related products), 73 (business services), and 87 (engineering and management services). Most of the firms with an industry classification in business services have a four-digit SIC between 7371 and 7375, which involves activities such as computer programming, computer processing, and information retrieval.

18 The estimated differential growth during the year of issuance is approximately 31 percent of the average firm growth in intangibles in our sample.
} 
capital investments, intangible investments take a longer time to influence output and sales. The ultimate impact on production and sales is thus more uncertain. For example, consider a non-high$R \& D$ firm that uses the funds raised in capital markets to buy machinery versus a high-R\&D firm that uses them to finance research on new production processes. The non-high-R\&D firm would be able to expand its production in the short-term and, thus, increase sales. In contrast, investment in research by the high-R\&D firm has a longer and more uncertain gestation period.

\section{Heterogeneity across Countries}

The evidence presented in previous sections suggests that countries with relatively well-developed capital markets, and stock markets in particular, tend to provide greater financing to small, young, and high-R\&D firms. In this section, we complement this evidence by studying the relation between capital market development and the composition of firms in terms of size, age, and R\&D intensity and then explore how the relation between firm growth and capital market issuances differs across countries with different financial system structures. The analysis of the performance of firms across different countries is important because capital market development (equity and corporate bond market capitalization) differs markedly across countries, especially when contrasted with bank development (credit to the private sector). For example, China's capital market development is 0.50 times bank development, whereas this ratio is approximately 4.08 in the United States (Appendix Figure 2).

To illustrate the connection between capital market development and the composition of firms in a country, we plot the distribution of firm size, age, and R\&D expenditures separately for marketand bank-based countries (Figure 4). To define a country as having a market- or bank-based financial system, we rank countries based on their average ratios of capital market development to bank development over the period 1991-2016 and classify those at the top-25 percent as market-based countries and those at the bottom-25 percent as bank-based countries. 
Countries with market-based financial systems have distributions of firm size and age that fall to the left of countries with bank-based systems, indicating that publicly listed firms in these countries are smaller and younger (Figure 4). For example, a firm at the $25^{\text {th }}$ percentile of the size distribution has on average US $\$ 11.73$ million in assets in countries with market-based financial systems, whereas it has on average US\$65.43 million in countries with bank-based systems. Similarly, market-based countries have a distribution of firms' $\mathrm{R} \& \mathrm{D}$ expenditures that fall to the right of the distribution for bank-based countries. For instance, a firm at the $75^{\text {th }}$ percentile of the $R \& D$ distribution invests on average US $\$ 15.78$ million in R\&D in market-based countries, whereas it invests on average US\$9.89 million in bank-based countries.

To assess the differences in firm composition across countries, we employ panel ordinary least squares regressions of firm size, age, and R\&D intensity on countries' financial structures. The regression specification is as follows:

$$
\log \left(Y_{\text {isct }}\right)=\gamma_{0}+\gamma_{1} \text { FinStructure }_{c t}+\gamma_{2} \boldsymbol{X}_{c t}+\eta_{t}+\varepsilon_{\text {isct }},
$$

where $Y_{i s c t}$ is either firm $i$ s total assets, age, or R\&D intensity. FinStructure $e_{c t}$ is the ratio of country ¿'s capital market development to bank development. In addition, $\boldsymbol{X}_{c t}$ is a vector of country-level controls. We consider two alternative set of control variables used in other studies on financial development and growth. One set of controls follows Brown et al. (2013) and includes the log of GDP per capita, the average rate of GDP growth during the sample period, the ratio of government expenditures to GDP, the inflation rate, and an index of rule of law. The other set of controls follows Brown et al. (2017) and includes the average years of secondary schooling attained, the ratio of trade to GDP, and the ratio of investment to GDP. Lastly, $\eta_{t}$ is a set of year-specific dummy variables accounting for shocks common to all countries in a given year. We cluster standard errors at the country level. 
The estimations indicate that there is a strong relation between the structure of a country's financial system and the composition of its listed firms (Table 8). The coefficient on FinStructure $_{c t}$ is statistically significant in all specifications, with a negative sign for firm size and age and a positive sign for firm R\&D intensity. These estimates reinforce the patterns implied by the distribution graphs, indicating that greater capital market development relative to bank development is associated with smaller, younger, and more R\&D-intensive listed firms. The results confirm the contrasting patterns of countries such as the United States (market-based) and China (bank-based). Listed firms in the United States are about 50 percent smaller and 187 percent more R\&D intensive than those in China, where the median firm has US\$242.66 million in assets and an R\&D intensity of 0.25 .

The composition of listed firms can play a role on the strength of the growth-issuance relation. Our previous results indicate that the average growth around issuances would tend to be larger in countries with a greater share of more financially constrained firms such as small, young, and high$\mathrm{R} \& \mathrm{D}$ firms. Moreover, firms in different countries might use the financing from capital markets in different ways. The evidence in the existing literature is sparse and does not show a significant difference across countries in how firms use the capital raised through equity issuances. We revisit this evidence using more data and examining more directly whether the relation between firm growth and capital market issuances differs across countries with different financial systems.

We work with our baseline specification (Equation 1) and include a variable on financial structure interacted with the issuance-window dummies. We estimate the following specification:

$$
\begin{aligned}
\text { Growth }_{i s c t}= & \gamma_{0}+\gamma_{1} \text { PreIss }_{i s c t}+\gamma_{2} \text { Issuance }_{i s c t}+\gamma_{3} \text { PostIss }_{i s c t} \\
& +\gamma_{4}\left(\text { PreIss }_{i s c t} * \text { FinStructure }_{c t}\right)+\gamma_{5}\left(\text { Issuance }_{i s c t} * \text { FinStructure }_{c t}\right) \\
& \left.+\gamma_{6} \text { PostIss }_{i s c t} * \text { FinStructure }_{c t}\right)+\delta_{i}+\omega_{c t}+\varepsilon_{i s c t} .
\end{aligned}
$$


We find that capital market issuances are associated with faster growth among issuing firms located in countries with greater capital market development relative to bank development (Table 9). The estimates of $\gamma_{5}$ are positive and statistically significant across all measures of firm growth, except for total assets. To evaluate the magnitude of this coefficient, we compare the difference in predicted growth for issuing firms in countries with market-based financial systems (such as the United States) vis-à-vis countries with bank-based financial systems (such as Germany and China). For example, the estimates for the year of issuance imply that issuing firms in Germany grow on average 3.79 percentage points faster than non-issuers in terms of employment. This growth differential is 5.62 percentage points smaller than that in the United States, which is an economically sizable difference given that employment growth for the average firm in the sample stood at 4.48 percent. In the case of China, the growth differential in employment between issuers and non-issuers is 6.17 percentage points smaller than that in the United States. Even within market-based countries, there could be sizable growth differentials. For example, the growth differential between issuers and non-issuers is 3.53 percentage points smaller in Chile than in the United States.

\section{Changes in Growth Opportunities}

The joint finding that issuers grow faster than non-issuers prior to the issuance of securities and that this growth differential significantly widens as firms issue securities is consistent with the view that issuers witness growth opportunities, and they use the funds raised through securities issuances to realize those growth opportunities. One concern with interpreting the findings in this way, however, is that we cannot observe growth opportunities at the firm level. We just find behavior consistent with the view that firms issue securities to realize growth opportunities.

To shed further light on this issue, we study the impact of changes to the growth opportunities of one industry: mining. We examine changes in mining prices in international markets. The basic idea 
is that higher mining prices create exogenous new growth opportunities for firms in that industry, as more projects become viable. To the extent that firms use capital markets to execute those projects, we should observe a higher propensity to issue by mining firms. Other papers have exploited a similar idea to study exogenous changes to international commodity prices and their effects on the banking system (Agarwal et al., 2017, 2020).

We begin by highlighting two key patterns. First, there is a positive correlation between mining prices and issuance activity of mining firms (Figure 5). As prices increase, issuances increase as well. This relation holds not only for aggregate mining prices, but also for specific commodities of the mining price index and for firms producing those products. Second, the increase in mining issuance activity does not reflect a generalized increase in activity across all industries. In fact, issuance activity for different industries exhibit very different patterns over time, with peaks and troughs spread over the years (Figure 6). In other words, fluctuations in mining prices do not reflect an aggregate shock (such as a lower cost of capital) that prompts output prices and issuances to increase for all industries. Instead, the patterns we show reflect industry specific fluctuations in both prices and issuances. Moreover, the correlation between prices and issuances are unlikely to stem from idiosyncratic decisions by firms to issue more to increase production. When these unilateral decisions take place (like for oil producers), output prices decline due to the higher supply of that product. ${ }^{19}$

Next, we use logit regressions to assess the relation between securities issuances and mining prices. Specifically, the dependent variable is a dummy variable of whether the firm issues a security $\left(\right.$ Issuance $\left._{i s c t}\right)$. The main explanatory variables are (1) the mining price index $\left(\right.$ Mining Price $\left._{t}\right)$, which is calculated as a weighted average of 18 mining commodity prices, (2) a dummy that equals one if a

\footnotetext{
${ }^{19}$ Contrary to the argument that increases in mining prices might reflect physical supply disruptions (especially in the oil industry), several papers find that oil price shocks historically have been driven by a combination of global aggregate demand shocks and precautionary demand shocks (Kilian, 2009; Kilian and Murphy, 2014).
} 
firm belongs to the mining industry $\left(\right.$ MiningDummy ${ }_{S}$, and (3) the interaction between the two. ${ }^{20}$ As controls, the regressions include one-year lagged values of the consumer price index to capture general output prices, GDP growth to capture overall demand $\left(\boldsymbol{X}_{c t}\right)$, and the VIX volatility index, the U.S. Treasury rate, and the Global Dow Index to capture overall market conditions for firm financing $\left(\boldsymbol{Y}_{t}\right)$. Some specifications also control for country and industry fixed effects (at the four-digit SIC level). We estimate these regressions for both equity and bond issuances together, and separately. The regression specification is as follows:

$$
\begin{aligned}
\text { Issuance }_{\text {isct }} & =\gamma_{0}+\gamma_{1} \text { MiningPrice }_{t}+\gamma_{2} \text { MiningDummy }_{s} \\
& +\left(\text { MiningPrice }_{t} * \text { MiningDummy }_{s}\right)+\boldsymbol{X}_{c t}+\boldsymbol{Y}_{t}+\eta_{s}+\alpha_{c}+\varepsilon_{i s c t}
\end{aligned}
$$

The results suggest that mining companies are more likely to issue whenever the prices of the mining industry increase (Table 10). This holds across specifications with similar point estimates. Issuances of firms in other industries do not appear to respond to mining prices. The marginal effects of those estimations show that, for example, when the mining price index goes from 50 to 100 , the probability of issuance for mining firms jumps from 11 percent to 21 percent (Figure 7). That is, aside from any effect that global financial conditions might have on the probability of issuance, these results suggest that higher output prices induce firms to issue more equity and bonds.

\section{Conclusions}

The debate about the link between finance and growth has occupied economists for a long time. Most of this debate has focused on country-level evidence that shows a positive link between financial sector

\footnotetext{
20 The mining price index is constructed as a weighted average of the prices of aluminum, chloride, coal, cobalt, copper, gas, gold, iron, lead, nickel, oil, palladium, platinum, potassium phosphate rock, silver, tin, uranium, and zinc. The weights are calculated based on the commodity's global import share over the period 2014-16. Prices are normalized to 100 at year 2010 .
} 
development and national growth. Using data for firms from around the world, we contribute to this debate by studying whether the link also exists at the firm level.

There are four key findings in this paper. First, firms experience a boost in sales and asset growth and an increase in productive capabilities-tangible assets, intangible assets, and employment—when raising funds in capital markets. These findings indicate that firms are not using the new funds just to change their capital structure or increase financial investments. Second, firms that are ex ante more likely to be financially constrained-small, young, and high-R\&D firmsexperience a larger boost in growth around issuance. These findings are consistent with the idea that capital markets allow financially constrained firms to relax their funding restrictions and grow. Furthermore, equity (but not bond) issuances have an especially strong, positive link with intangible investments by high-R\&D firms. This finding contributes to research on the question of whether equity markets have a comparative advantage in funding more opaque investments. Third, countries with greater capital market development have a higher proportion of smaller, younger, and innovative listed firms than more bank-based countries. Furthermore, firms in countries with relatively welldeveloped capital markets experience a larger boost in growth when issuing securities than firms in bank-based financial systems. These findings contribute to research on debates concerning the connections between financial architecture and financing of different types of firms and activities. Fourth, firms that experience exogeneous changes in growth opportunities are more likely to issue securities in capital markets. This is consistent with the view that firms use capital markets to realize growth opportunities by expanding their productive capabilities.

The positive association between firms issuing securities and firm growth sheds new light on the debates concerning the mechanisms through which capital markets might influence growth. The evidence in this paper suggest that it is not just that firms grow faster in countries with better functioning capital markets. Rather, we find that issuers (especially smaller, younger, and higher-R\&D 
intensive ones) grow faster than non-issuers as they raise capital, after controlling for different effects. This evidence does not reject theories that predict that firms do not need to sell securities to reap the benefits of better capital markets, but it does establish that there is a strong positive relation between issuance and firm growth across a wide array of countries. Future research would need to identify the degree to which supply side factors (such as shocks that relax financing constraints) drive the positive association between capital raising and firm growth, and how much demand side factors (such as high growth opportunities) prompt firms to tap capital markets. Moreover, because some of the benefits of more developed capital markets are only directly accrued by some firms, further research would also need to study the possible indirect benefits to other firms that do not raise funds in these markets.

The fact that issuers grow faster than non-issuers might have consequences for the firm size distribution. Issuers will become larger over time, so the firm size distribution would tend to widen. But among issuers, smaller firms grow faster than larger firms. So smaller firms might catch up with larger firms. The implications of these different growth rates for the overall firm size distribution of listed and non-listed firms remain material for future work. This might have consequences for the amount of financing that issuers receive as they become larger, as well as their preponderance in the overall economic activity across countries. Understanding these distributional effects across firms has gained attention and will remain a subject of intense scrutiny. 


\section{References}

Acemoglu, D., and F. Zilibotti, 1997. Was Prometheus unbound by chance? Risk, diversification, and growth. Journal of Political Economy 105(4), 709-51.

Agarwal, S., R. Correa, B. Morais, J. Roldan, C. Ruiz-Ortega, 2020. Owe a bank millions, the bank has a problem: Credit concentration in bad times. World Bank Policy Research Working Paper Series 9202.

Agrawal, I., R. Duttagupta, and A. Presbitero, 2017. International commodity prices and domestic bank lending in developing countries. International Monetary Fund Working Paper 17/279.

Aghion, P., P. Howitt, and R. Levine, 2018. Financial development and innovation-led growth.” In: Handbook of Finance and Development, chapter 1, 3-30, (eds.) T. Beck and R. Levine. Edward Elgar Publishing Limited, Cheltenham.

Alden, W., 2014. First Data to raise \$3.5 billion to reduce debt. New York Times, June 19, 2014.

Almeida, H., M. Campello, and M.S. Weisbach, 2004. The cash flow sensitivity of cash. Journal of Finance 59(4), 1777-1804.

Arestis, P., P.O. Demetriades, and K.B. Luintel, 2001. Financial development and economic growth: The role of stock markets. Journal of Money, Credit and Banking 33(1), 16-41.

Atiase, R.W, 1985. Predisclosure information, firm capitalization, and security price behavior around earnings announcements. Journal of Accounting Research 23(1), 21-36.

Baker, M., and J. Wurgler, 2002. Market timing and capital structure. Journal of Finance 57(1), 1-32.

Barclay, M.J., L.M. Marx, and C.W. Smith, 2003. The joint determination of leverage and maturity. Journal of Corporate Finance 9, 149-167.

Bass, D., and M. Smith, 2018. Dell has 49 billion reasons to consider going public again. Bloomberg, January 26.

Beck, T., and A. Demirguc-Kunt, 2006. Small and medium-size enterprises: Access to finance as a growth constraint. Journal of Banking and Finance 30(11), 2931-2943.

Beck, T., A. Demirguc-Kunt, L. Laeven, and R. Levine, 2008. Finance, firm size, and growth. Journal of Money, Credit and Banking 40(7), 1379-1405.

Beck, T., A. Demirguc-Kunt, and V. Maksimovic, 2005. Financial and legal constraints to firm growth: Does size matter? Journal of Finance 60, 137-177.

Beck, T., and R. Levine, 2002. Industry growth and capital allocation: Does having a market- or bankbased system matter? Journal of Financial Economics 64(2), 147-180.

Beck, T., and R. Levine, 2004. Stock markets, banks, and growth: panel evidence. Journal of Banking and Finance 28(3), 423-442.

Bekaert, G., C. Harvey, and C. Lundblad, 2005. Does financial liberalization spur economic growth? Journal of Financial Economics 77(1), 3-55.

Bhushan, R., 1989. Firm characteristics and analyst following. Journal of Accounting and Economics 11, 255-274.

Billett, M.T., T-H.D. King, and D.C. Mauer, 2007. Growth opportunities and the choice of leverage, debt maturity, and covenants. Journal of Finance 62(2), 697-730.

Bolton, P., and X. Freixas, 2000. Equity, bonds, and bank debt: Capital structure and financial market equilibrium under asymmetric information. Journal of Political Economy 108(2), 324-351.

Borisova, G., and J.R. Brown, 2013. R\&D sensitivity to asset sale proceeds: New evidence on financing constraints and intangible investment. Journal of Banking and Finance 37(1), 159-173.

Bougheas, S., H. Gorg, and E. Strobl, 2003. Is R\&D financially constrained? Theory and evidence from Irish manufacturing. Review of Industrial Organization 22, 159-174.

Boyd, J.H., and B.D. Smith, 1998. The evolution of debt and equity markets in economic development. Economic Theory 12(3), 519-560. 
Brown, J.R., and B.C. Petersen, 2009. Why has the investment-cash flow sensitivity declined so sharply? Rising R\&D and equity market developments. Journal of Banking and Finance 33(5), 971-984.

Brown, J.R., and I.V. Floros, 2012. Access to private equity and real firm activity: Evidence from PIPEs. Journal of Corporate Finance 18, 151-165.

Brown, J.R., S.M. Fazzari, and B.C. Petersen, 2009. Financing innovation and growth: Cash flow, external equity, and the 1990s R\&D boom. Journal of Finance 64(1), 151-185.

Brown, J.R., G. Martinsson, and B.C. Petersen, 2013. Law, stock markets, and innovation. Journal of Finance 68(4), 1517-1549.

Brown, J.R., G. Martinsson, and B.C. Petersen, 2017. Stock markets, credit markets, and technologyled growth. Journal of Financial Intermediation 32, 45-59.

Bruno, V., Shin, H., 2017. Global dollar credit and carry trades: A firm-level analysis. Review of Financial Studies 30(3), 703-749.

Calomiris, C., M. Larrain, and S. Schmukler, 2020. Capital inflows, equity issuance activity, and corporate investment. Journal of Financial Intermediation, forthcoming.

Calomiris, C., M. Larrain, S. Schmukler, and T. Williams, 2019. Search for yield in large international corporate bonds: Investor behavior and firm responses. NBER Working Paper 25979.

Campello, M., and D. Hackbarth, 2012. The firm-level credit multiplier. Journal of Financial Intermediation 21(3), 446-472.

Carpenter, R.E., and B.C. Petersen, 2002. Is the growth of small firms constrained by internal finance? Review of Economics and Statistics 84 (2), 298-309.

Carpenter, R.E. and A. Guariglia, 2008. Cash flow, investment, and investment opportunities: New tests using UK panel data. Journal of Banking and Finance 32(9), 1894-1906.

Carreira, C., and F. Silva, 2010. No deep pockets: Some stylized empirical results on firms' financial constraints. Journal of Economic Surveys 24(4), 731-753.

Chakraborty, S., and T. Ray, 2006. Bank-based versus market-based financial systems: A growththeoretic analysis. Journal of Monetary Economics 53(2), 329-350.

Caputo, R., and A. Irarrazabal, 2017. The business cycle of a commodity exporter. Central Bank of Chile, mimeo.

Chang, X., S. Dasgupta, and G. Hilary, 2006. Analyst coverage and financing decisions. Journal of Finance 61(6), 3009-3048.

Cihak, M., and A. Demirguc-Kunt, 2012. Financial structure and incentives. National Institute Economic Review 221(1), 23-30.

Claessens, S., and S. Schmukler, 2007. International financial integration through equity markets: Which firms from which countries go global? Journal of International Money and Finance 26(5), 788-813.

Collins, D.W., S.P. Kothari, and J.D. Rayburn, 1987. Firm size and the information content of prices with respect to earnings. Journal of Accounting and Economics 9(2), 111-138.

Czarnitzki, D., and A. Hottenrott, 2011. R\&D investment and financing constraints of small and medium-sized firms. Small Business Economics 36(1), 65-83.

Da Rin, M., G. Nicodano, and A. Sembenelli, 2006. Public policy and the creation of active venture capital markets. Journal of Public Economics 90(8-9), 1699-1723.

De Angelo, H., L. De Angelo, and R. Stulz, 2010. Seasoned equity offerings, market timing, and the corporate lifecycle. Journal of Financial Economics 95(1), 275-295.

Demirguc-Kunt, A., and R. Levine, 2004. Financial structure and economic growth: A cross-country comparison of banks, markets, and development. Cambridge, MA: MIT Press.

Demirguc-Kunt, A., E. Feyen, and R. Levine, 2013. The evolving importance of banks and securities markets. World Bank Economic Review 27(8), 476-490. 
Demirguc-Kunt, A., and V. Maksimovic, 1998. Law, finance, and firm growth. Journal of Finance 53(6), 2107-2137.

Demirguc-Kunt, A., and V. Maksimovic, 2002. Funding growth in bank-based and market-based financial systems: Evidence from firm-level data. Journal of Financial Economics 65(3), 337-363.

Drechsel, T., and S. Tenreyro, 2018. Commodity booms and busts in emerging economies. Journal of International Economics 112, 200-218.

Erel, I., Y. Jang, and M.S. Weisbach, 2015. Do acquisitions relieve target firms' financial constraints? Journal of Finance 70(1), 289-328.

Fan, P., 2019. Debt retirement at IPO and firm growth. Journal of Economics and Business 101, 1-16.

Fazzari, S., R. Hubbard, and B. Petersen, 1988. Financing constraints and corporate investment. Brookings Papers on Economic Activity 1, 141-195.

Fernández, A., S. Schmitt-Grohé, and M. Uribe, 2017. World shocks, world prices, and business cycles: An empirical investigation. Journal of International Economics 108 S1, S2-S14.

Fluck, Z., 1998. Optimal financial contracting: Debt versus outside equity. Review of Financial Studies 11(2), 383-418.

Gatchev, V.A., P.A. Spindt, and V. Tarhan, 2009. How do firms finance their investments? The relative importance of equity issuance and debt contracting costs. Journal of Corporate Finance 15, 179-195.

Gilchrist, S. and C.P. Himmelberg, 1995. Evidence on the role of cash flow for investment. Journal of Monetary Economics 36, 541-572.

Gozzi, J.C., R. Levine, and S. Schmukler, 2008. Internationalization and the evolution of corporate valuation. Journal of Financial Economics 88(3), 607-632.

Gozzi, J.C., R. Levine, and S. Schmukler, 2010. Patterns of international capital raisings. Journal of International Economics 80(1), 45-57.

Gul, F.A., 1999. Growth opportunities, capital structure, and dividend policies in Japan. Journal of Corporate Finance 5, 141-168.

Hadlock, C.J. and J. Pierce, 2010. New evidence on measuring financial constraints: Moving beyond the KZ index. Review of Financial Studies 23(5), 1909-1940.

Hall, B.H, 2002. The financing of research and development. Oxford Review of Economic Policy 18(1), 3551.

Hall, B.H., and J. Lerner, 2010. The financing of R\&D and innovation. In: Handbook of the Economics of Innovation, vol. 1, chapter 14, 609-640, (eds.) B.H. Hall and N. Rosenberg. North-Holland, Amsterdam.

Henry, P.B., 2000. Stock market liberalization, economic reform, and emerging market equity prices. Journal of Finance 55(2), 529-564.

Hertzel, M., and Z. Li, 2010. Behavioral and rational explanations of stock price performance around SEOs: Evidence from a decomposition of market-to-book ratios. Journal of Financial and Quantitative Analysis 45(4), 935-958.

Himmelberg, C.P., and B.C. Petersen, 1994. R\&D and internal finance: A panel study of small firms in high-tech industries. Review of Economics and Statistics 76(1), 38-51.

Holmström, B., and J. Tirole, 1993. Market liquidity and performance monitoring. Journal of Political Economy 101(4), 678-709.

Hosono, K., 2003. Growth opportunities, collateral and debt structure: The case of the Japanese machine manufacturing firms. Japan and the World Economy 15, 275-297.

Hsu, P-H., X. Tian, and Y. Xu, 2014. Financial development and innovation: Cross-country evidence. Journal of Financial Economics 112, 116-135.

Hovakimian, A., G. Hovakimian, and H. Tehranian, 2004. Determinants of target capital structure: The case of dual debt and equity issues. Journal of Financial Economics 71, 517-540. 
Jensen, M.C., and W.H. Meckling, 1976. Theory of the firm: Managerial behavior, agency costs, and ownership structure. Journal of Financial Economics 3(4), 305-360.

Johnson, S.A., 2003. Debt maturity and the effects of growth opportunities and liquidity risk on leverage. Review of Financial Studies 16(1), 209-236.

Karolyi, A., 2006. The world of cross-listings and cross-listings of the world: Challenging conventional wisdom. Review of Finance 10(1), 99-152.

Kilian, L., 2009. Not all oil price shocks are alike: Disentangling demand and supply shocks in the crude oil market. American Economic Review 99(3), 1053-1069.

Kilian, L., and D.P. Murphy, 2014. The role of inventories and speculative trading in the global market for crude oil. Journal of Applied Econometrics 29, 454-478.

Kim, W., and M.S. Weisbach, 2008. Motivations for public equity offers: An international perspective. Journal of Financial Economics 87, 281-307.

La Porta, R., F. Lopez-de-Silanes, A. Shleifer, and R.W. Vishny, 1997. Legal determinants of external finance. Journal of Finance 52(3), 1131-1150.

Levine, R., 1991. Stock markets, growth, and tax policy. Journal of Finance 46(4), 1445-1465.

Levine, R., 2005. Finance and growth: Theory and evidence. In: Handbook of Economic Growth, chapter 12, 865-934, (eds.) P. Aghion and S. Durlauf. North-Holland Elsevier Publishers, Amsterdam.

Levine, R., 2002. Bank-based or market-based financial systems: which is better? Journal of Financial Intermediation 11(4), 398-428.

Levine, R., and S. Zervos, 1996. Stock market development and long-run growth. World Bank Economic Review 10(2), 323-339.

Levine, R., and S. Zervos, 1998. Stock markets, banks, and economic growth. American Economic Review 88(3), 559-586.

Luintel, K.B., M. Khan, R. Leon-Gonzalez, and G. Li, 2016. Financial development, structure, and growth: New data, method, and results. Journal of International Financial Markets, Institutions, and Money 43, 95-112.

Makan, A., and T. Demos, 2012. Apollo unit plans \$1bn IPO to reduce debt. Financial Times, June 8, 2012.

Marsh, P., 1982. The choice between equity and debt: An empirical study. Journal of Finance 37(1), 121 144.

McLean, R.D., 2011. Share issuance and cash savings. Journal of Financial Economics 99, 693-715.

McLean, R.D., and M. Zhao, 2018. Cash savings and capital markets. Journal of Empirical Finance 47, 49-64.

Mulier, K., K. Schoors, and B. Merlevede, 2016. Investment-cash flow sensitivity and financial constraints: Evidence from unquoted European SMEs. Journal of Banking and Finance 73, 182197.

Myers, S.C., 1977. Determinants of corporate borrowing. Journal of Financial Economics 5(2), 147-175.

Ndikumana, L., 2005. Financial development, financial structure, and domestic investment: International evidence. Journal of International Money and Finance 24(4), 651-673.

Obstfeld, M., 1994. Risk-taking, global diversification, and growth. American Economic Review 84(5), 1310-1329.

Oliveira, B., and A. Fortunato, 2006. Firm growth and liquidity constraints: A dynamic analysis. Small Business Economics 27(2-3), 139-156.

Pagano, M., F. Panetta, and L. Zingales, 1998. Why do companies go public? An empirical analysis. Journal of Finance 53(1), 27-64.

Popov, A., 2018. Evidence on finance and economic growth. In: Handbook of Finance and Development, chapter 3, 63-104, (eds.) T. Beck and R. Levine. Edward Elgar Publishing Limited, Cheltenham. 
Rajan, R.G., and L. Zingales, 1995. What do we know about capital structure? Some evidence from international data. Journal of Finance 50(5), 1421-1460.

Rajan, R.G., and L. Zingales, 1998. Financial dependence and growth. American Economic Review 88(3), 559-586.

Seven, U., and H. Yetkiner, 2016. Financial intermediation and economic growth: Does income matter? Economic Systems 40(1), 39-58.

Shin, H., and L. Zhao, 2013. Firms as surrogate intermediaries: Evidence from emerging economies. Asian Development Bank, mimeo.

Tadesse, S., 2002. Financial architecture and economic performance: International evidence. Journal of Financial Intermediation 11(4), 429-454.

Valdes, R., 2018. Reflexiones prácticas con 842 días en Hacienda. Estudios Públicos 150, 235-290.

Wu, X., and C.K. Au Yeung, 2012. Firm growth type and capital structure persistence. Journal of Banking and Finance 36, 3427-3443. 
FIGURE 1. SIZE OF THE FINANCIAL SYSTEM

This figure shows claims on the private sector by deposit money banks and capital market capitalization (including equity and corporate bonds) as a percentage of GDP between 1991 and 2016. The reported statistics are the median across countries of the over-time average for each country for each subperiod.

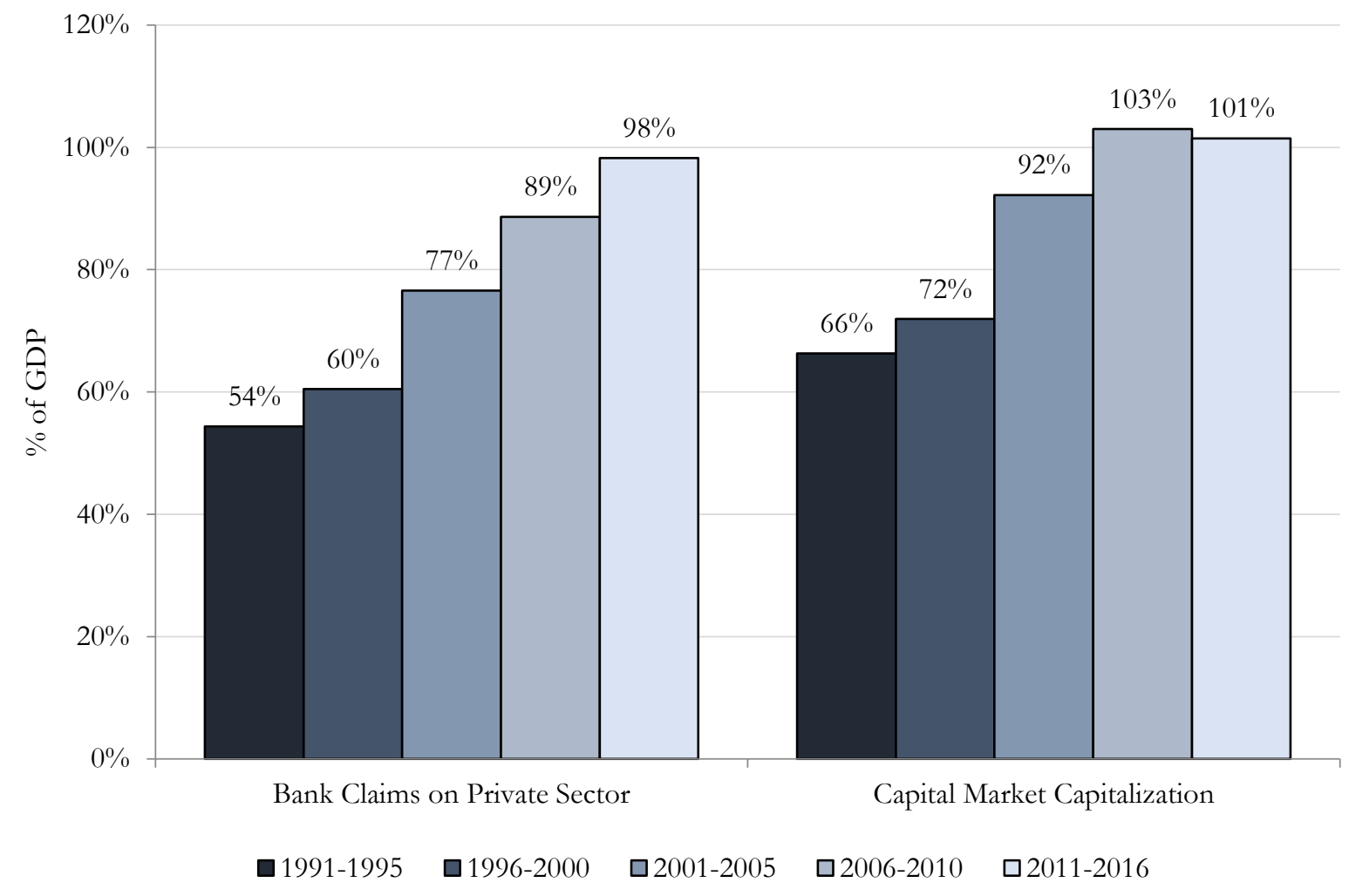


FIGURE 2. CUMULATIVE GROWTH DIFFERENTIAL

This figure shows the cumulative growth differential between issuers and non-issuers around a 5 -year issuance window. It shows the growth differentials for total assets, sales, number of employees, property, plant, and equipment, and intangible assets. The estimates are calculated based on the regression coefficients reported in Table 2. The figure considers three different definitions of issuing firms: equity issuers, bond issuers, and both equity and bond issuers (capital market issuers). For each definition, the figure shows the cumulative growth differential around the issuance years vis-à-vis the growth rate of all the firms in the sample during their non-issuance years. Year $t$ refers to the year of issuance. Growth rates for both issuers and non-issuers are normalized to 100 in year $t-3$. The years $t-2$ and $t-1(t+2$ and $t+1)$ refer to the pre-issuance (post-issuance) period.

\section{A. Total Assets}

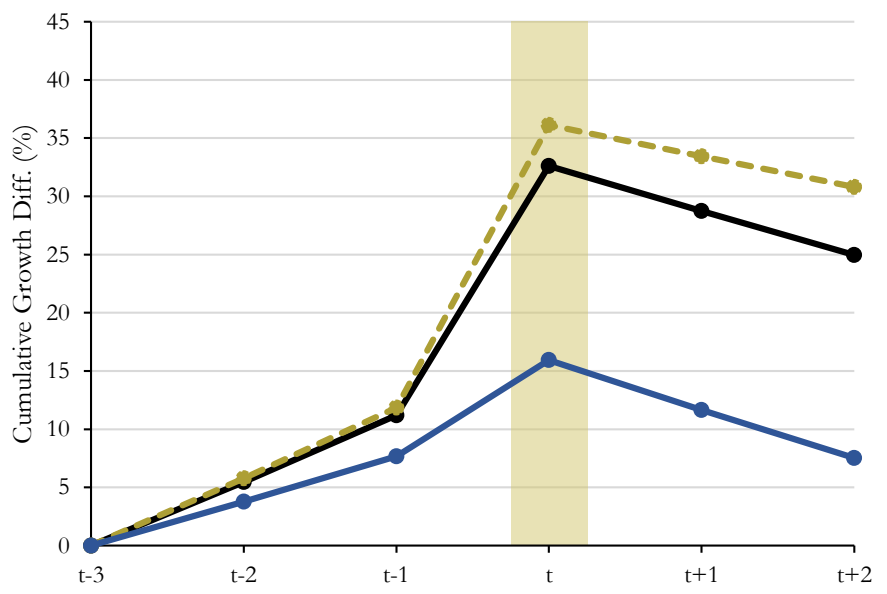

C. Number of Employees

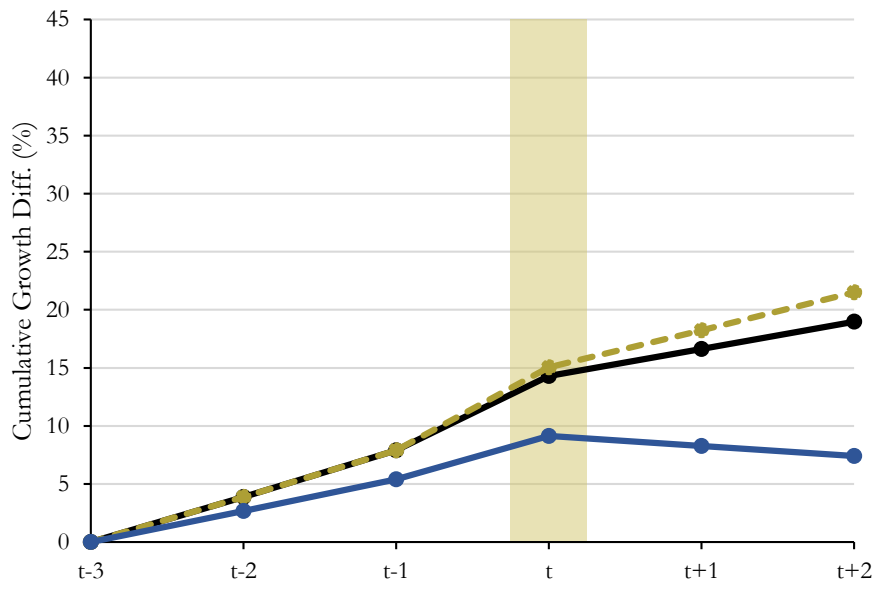

E. Intangible Assets

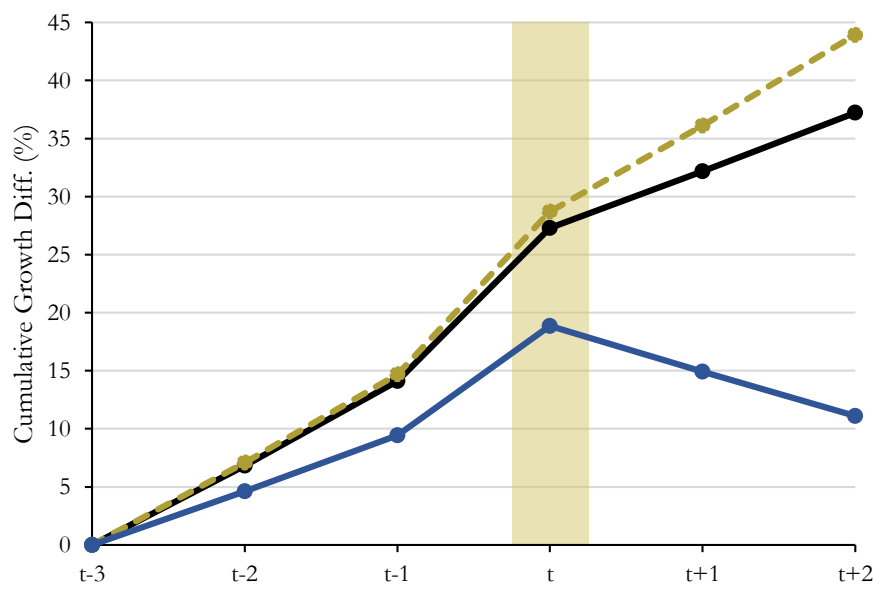

B. Sales

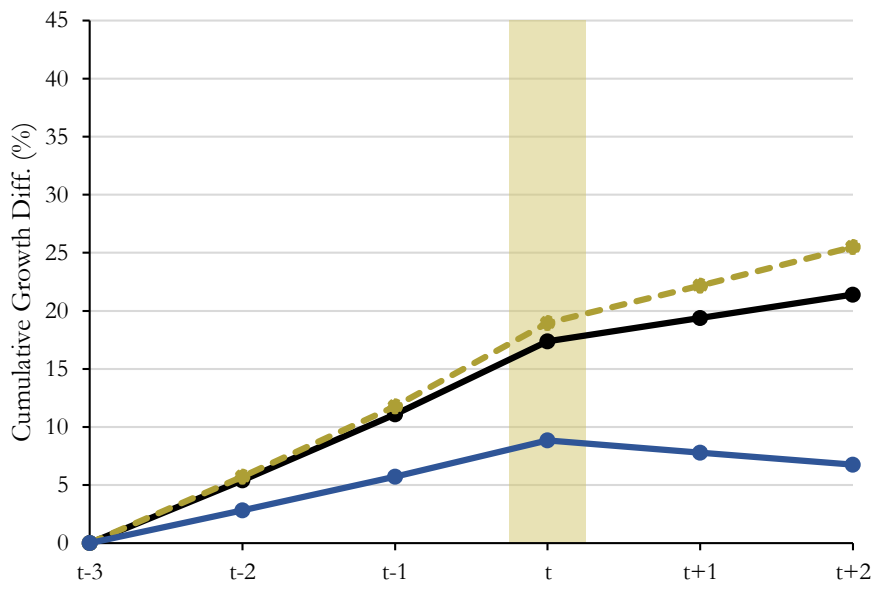

D. Property, Plant, and Equipment

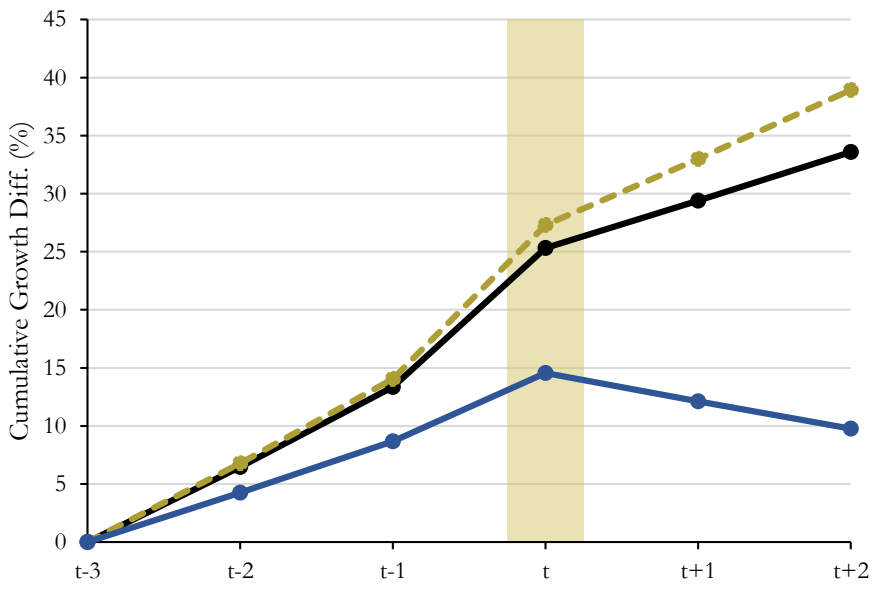


FIGURE 3. HETEROGENEITY ACROSS FIRMS

This figure shows the estimated annual growth rate differential in total assets between issuers and non-issuers at the year of issuance for each decile of the distributions of firm size (Panel A), age (Panel B), and R\&D intensity (Panel C). The statistics shown in this figure are obtained from the estimation of quantile regressions using the specification described in Table 2 for each decile of the distribution. The shaded area shows the confidence interval around those estimates at the $95 \%$ statistical confidence level. Firm size is measured as the log of total assets and R\&D intensity as the log of R\&D-to-total investment. Firms are assigned into each decile based on their median size, age, and R\&D intensity over the sample period.

\section{A. Size Distribution}

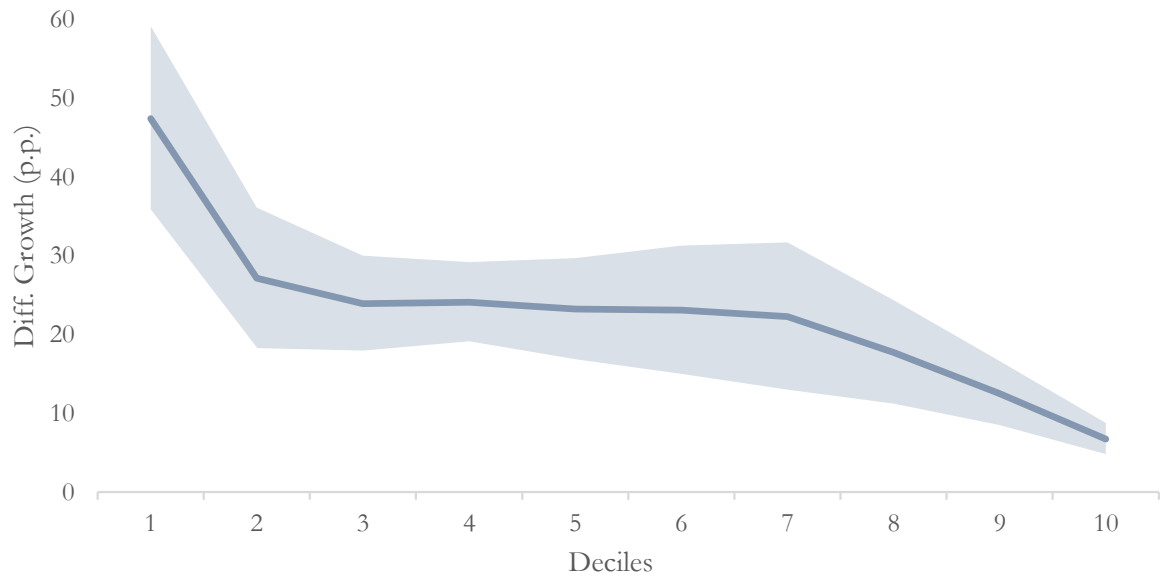

B. Age Distribution

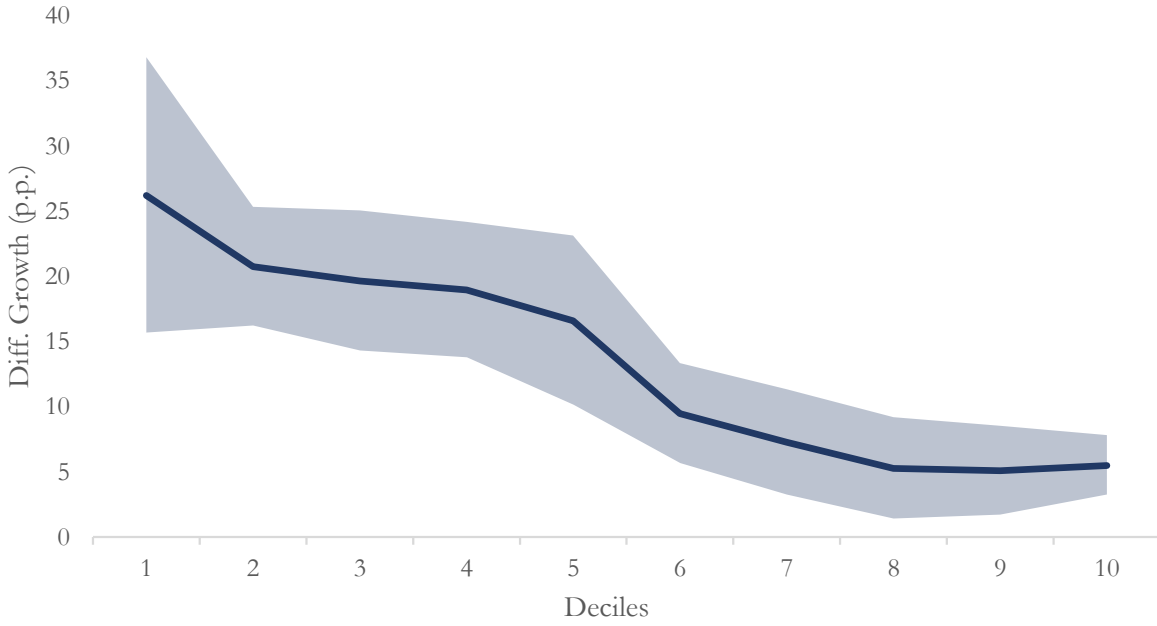

C. R\&D Intensity Distribution

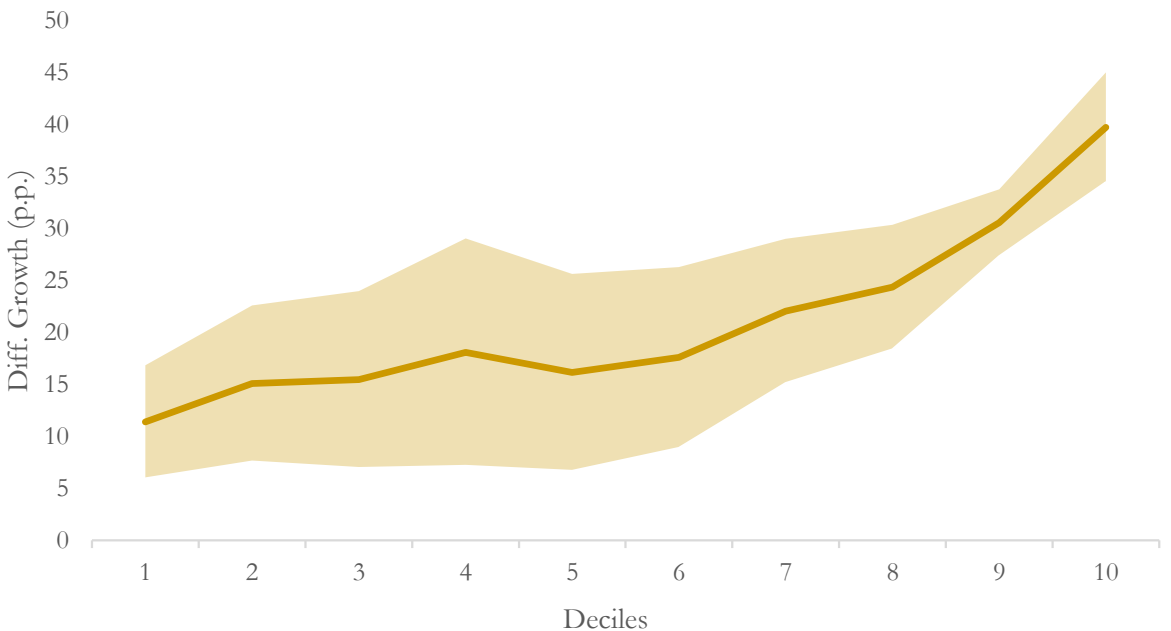


FIGURE 4. HETEROGENEITY ACROSS COUNTRIES

This figure shows the estimated kernel distributions of the log of firm size, age, and R\&D for countries with market-based (solid line) and bank-based (dashed line) financial systems. Countries are classified as market-based (bank-based) if their average ratio of capital market to bank development during the 1991-2016 period is in the top (bottom) $25^{\text {th }}$ percentile of the distribution across countries. The kernel used is a Gaussian distribution with a bandwidth of 1.5. The figure also shows the Kolmogorov-Smirnov (K-S) tests of equality of distributions. *, **, and *** denote statistical significance at $10 \%, 5 \%$, and $1 \%$, respectively.

\section{A. Size Distribution}

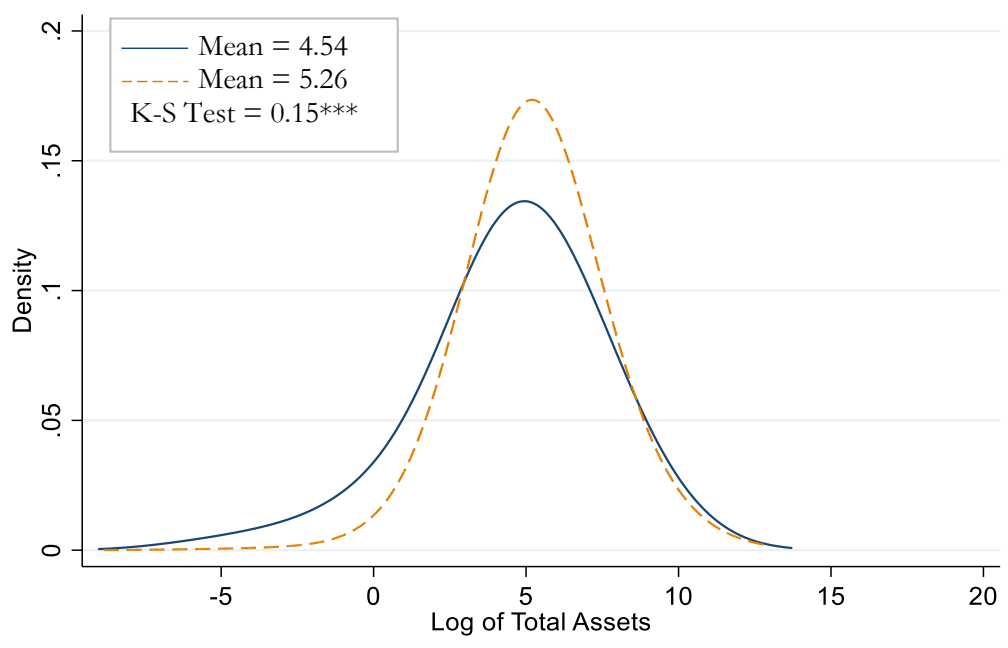

B. Age Distribution

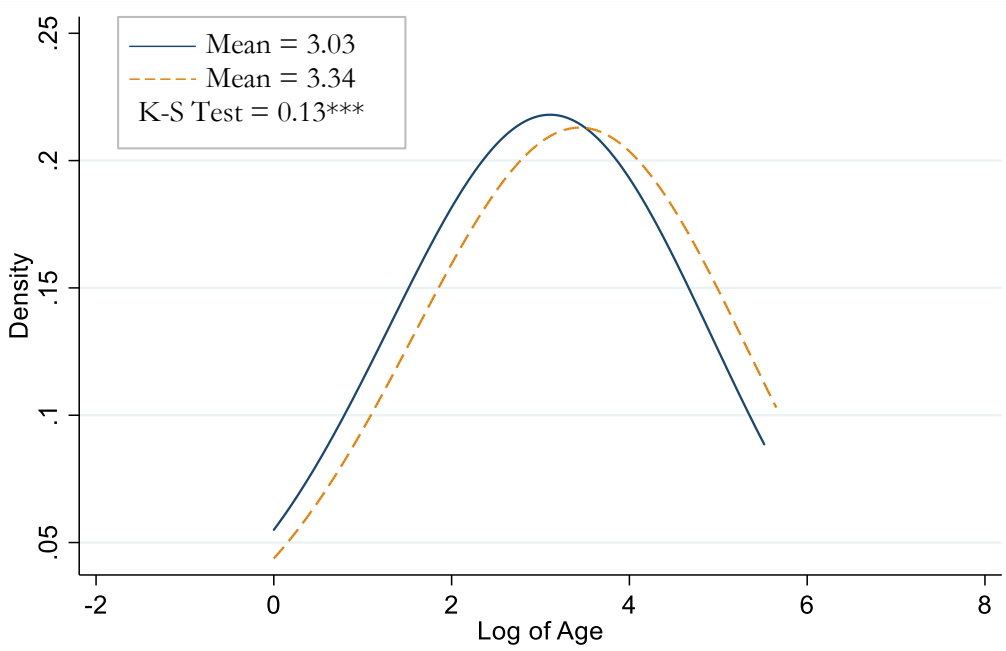

C. R\&D Distribution

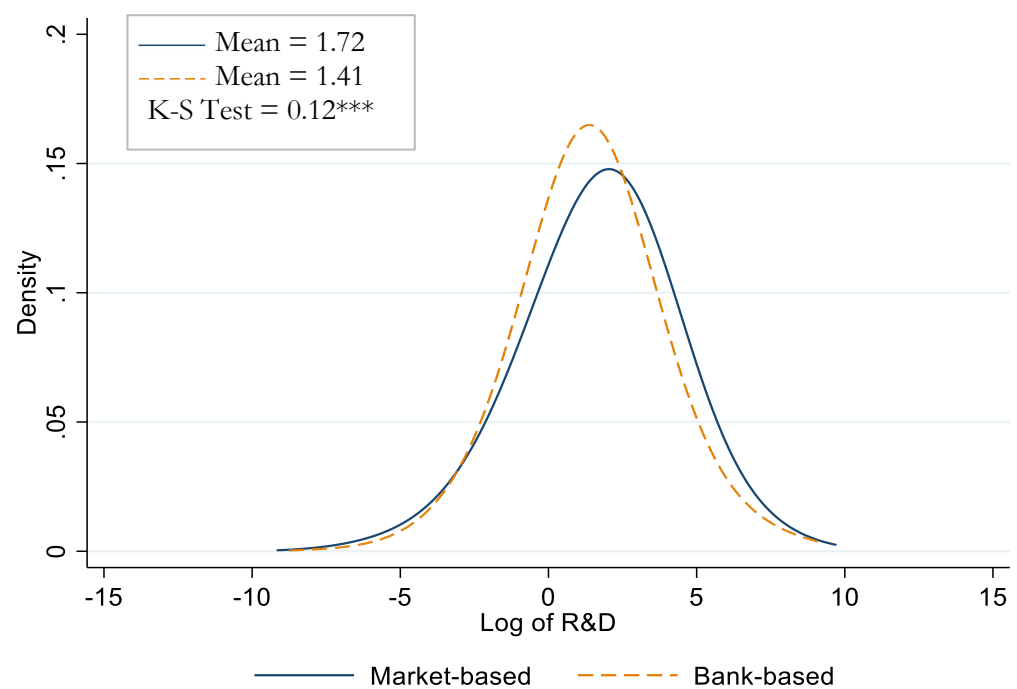


FIGURE 5. CAPITAL MARKET FINANCING AND INDUSTRY PRICES

This figure shows the amount raised per year in capital markets and the annual commodity price index for the mining industry as a whole (Panel A) and for a subgroup of mining commodities (Panels B-F). Prices are normalized to 100 in year 2010. The price index for the overall mining industry is a weighted average of 18 commodity prices. The weight is calculated based on the commodity's global import share over the period 2014-16. Issuance volumes are reported in millions of constant 2011 U.S. dollars.

\section{A. Mining}

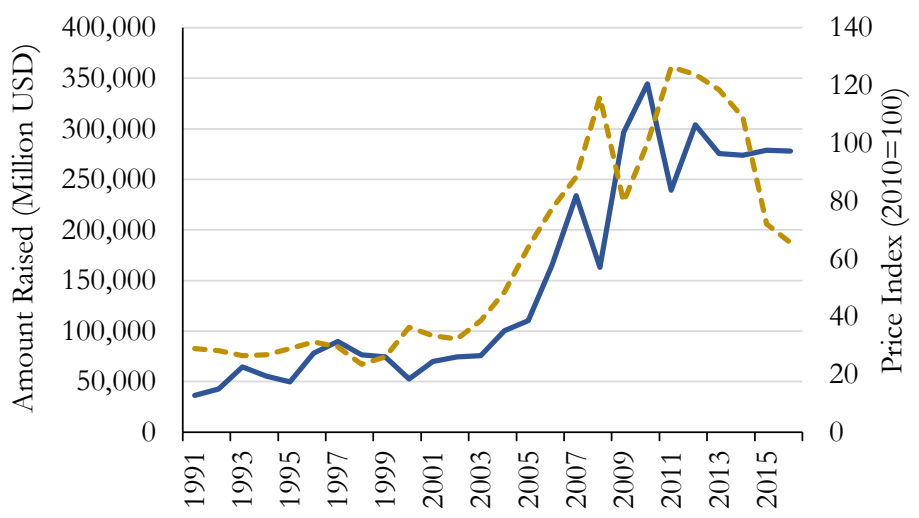

\section{Copper}

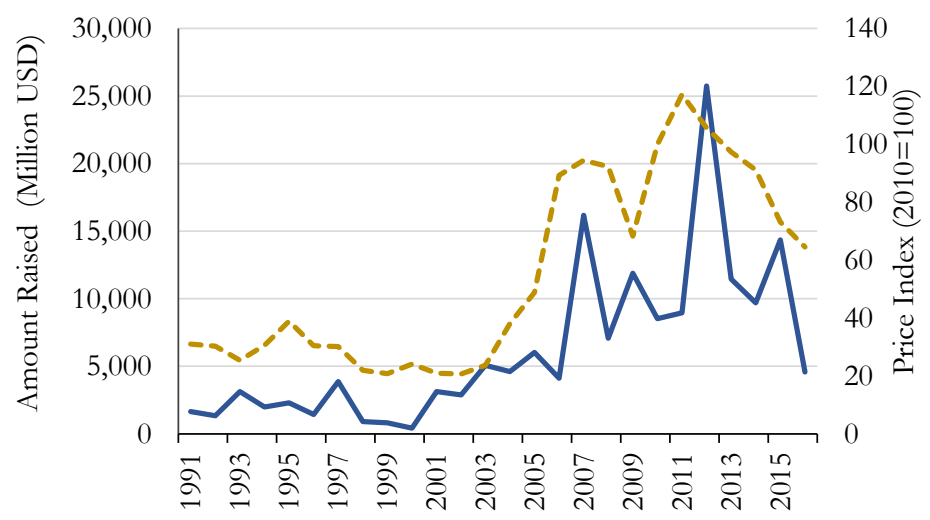

E. Iron

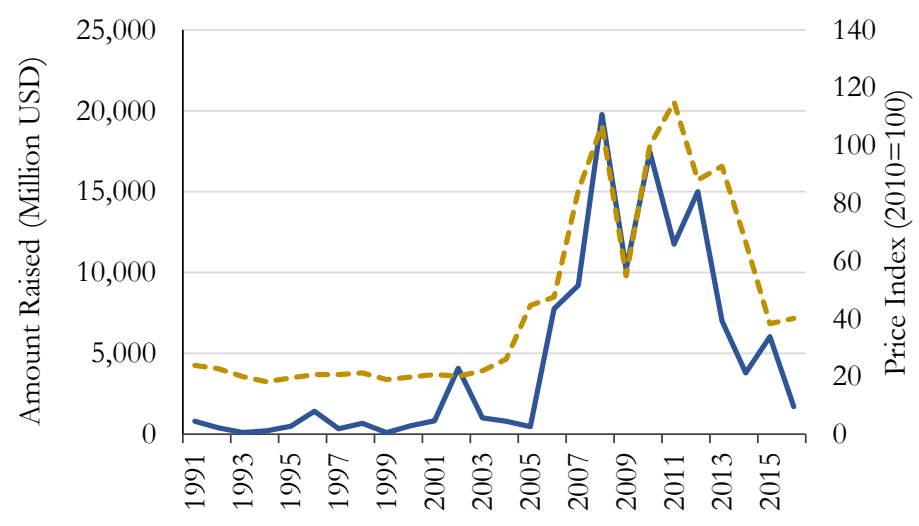

— Issuance in Capital Markets

\section{B. Coal Copper}

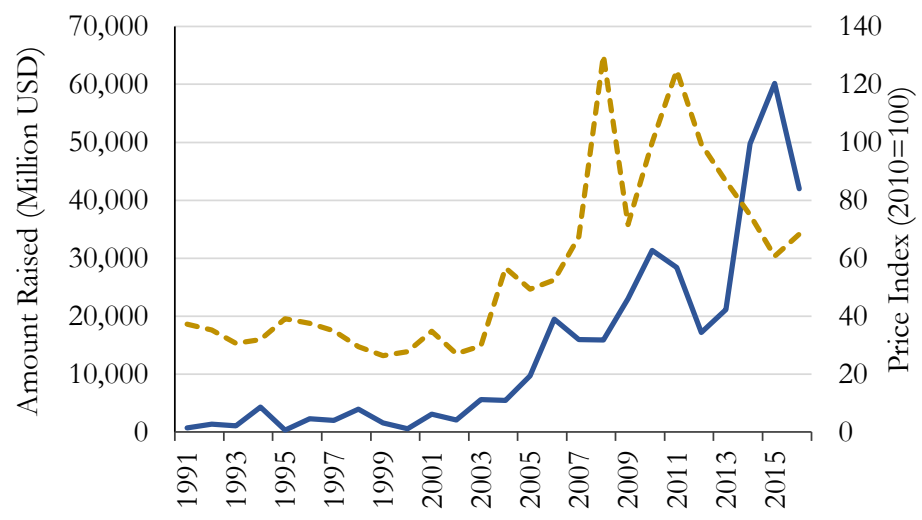

\section{Ferroalloy Ores}

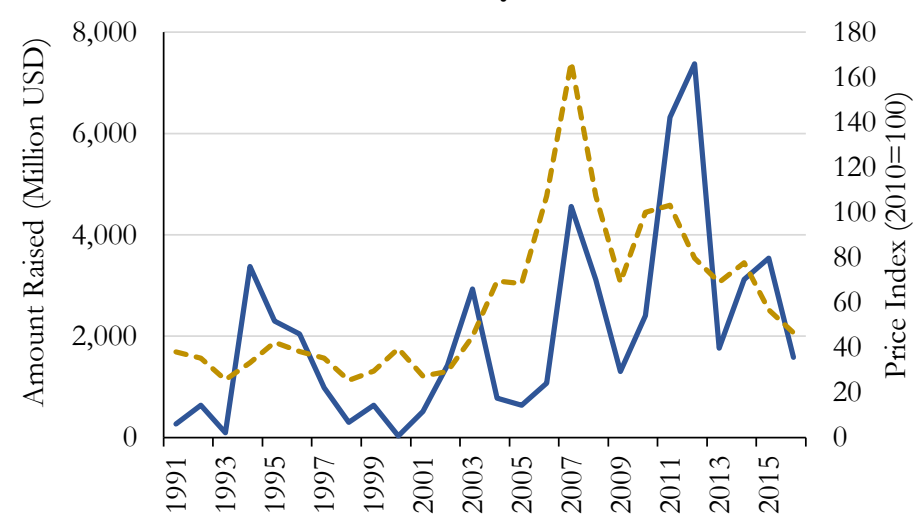

F. Zinc and Lead

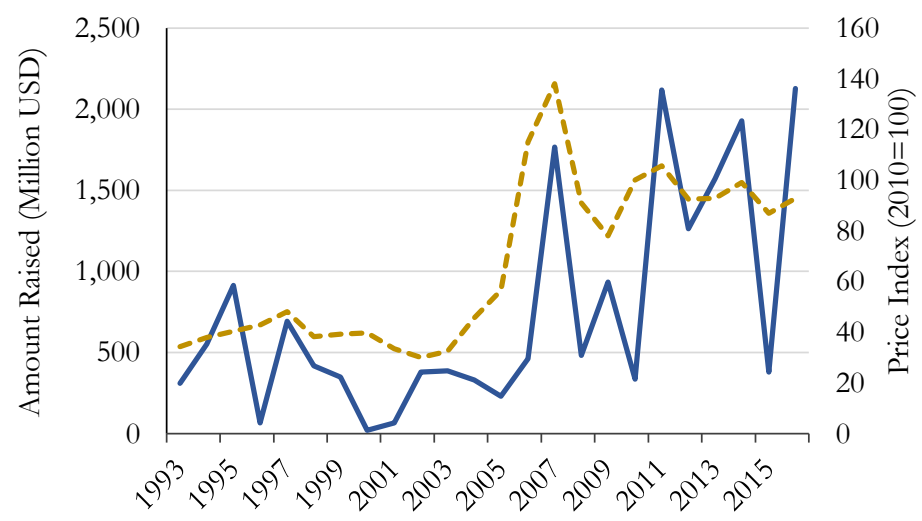

- - - Commodity Price Index 


\section{FIGURE 6. CAPITAL MARKET FINANCING ACROSS INDUSTRIES}

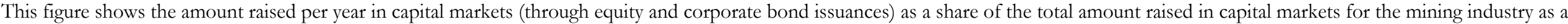
whole (Panel A) and for a subgroup of mining commodities (Panels B-H).

A. Mining

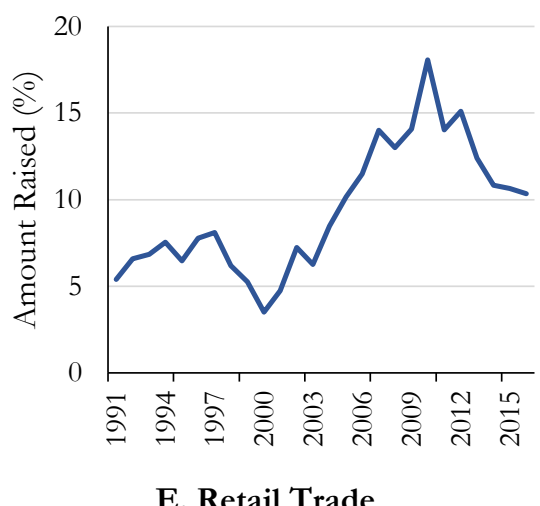

E. Retail Trade

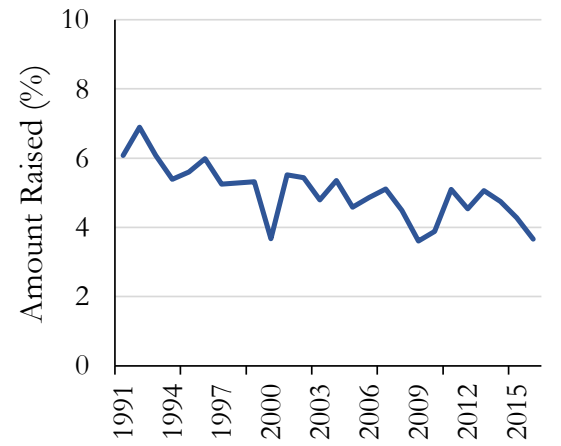

B. Agriculture, Forestry, and Fishing

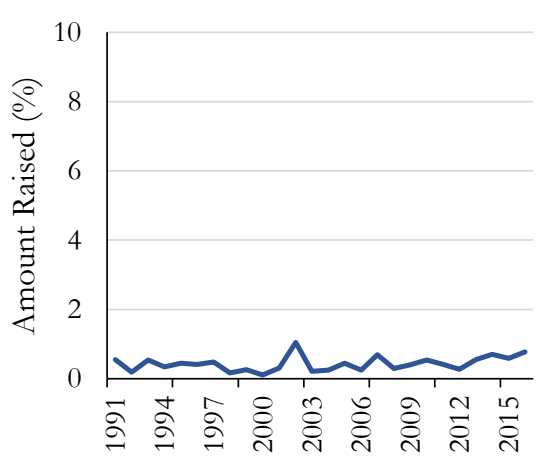

F. Services

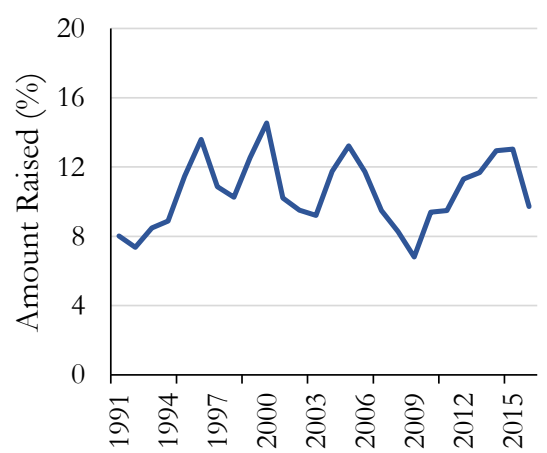

C. Construction

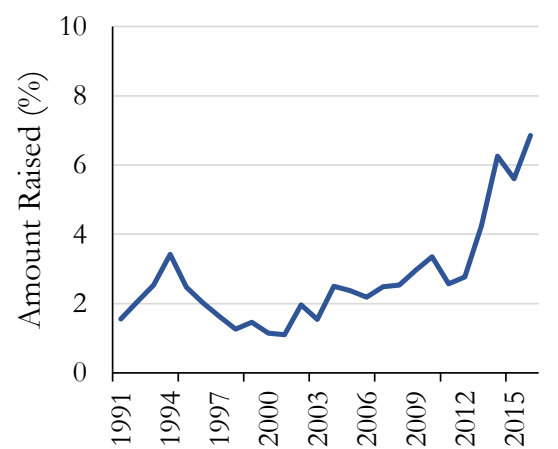

G. Transportation and Utilities

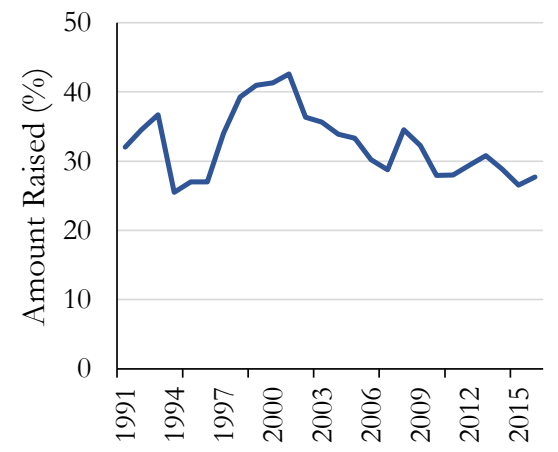

D. Manufacturing

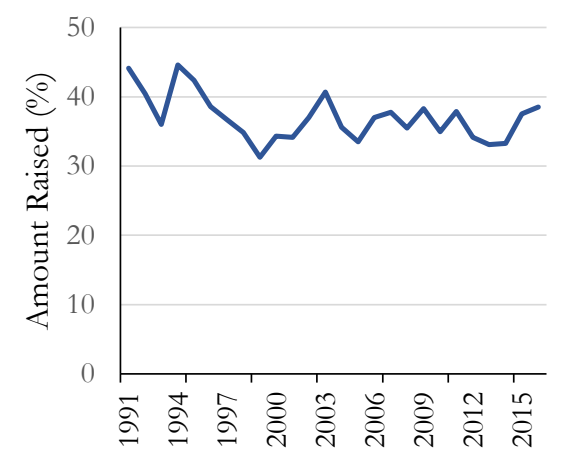

H. Wholesale Trade

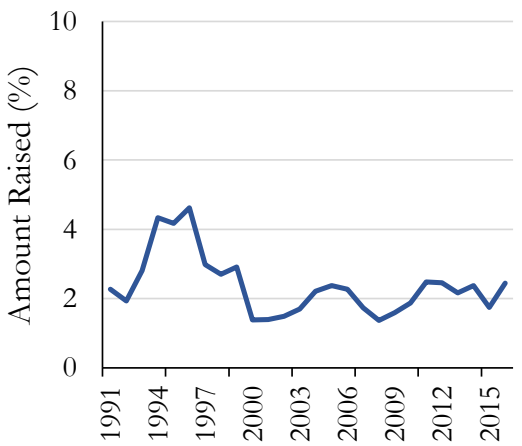


FIGURE 7. PROBABILITY OF ISSUANCE AND INDUSTRY PRICES

This figure shows the estimated probability of issuance in capital markets for firms in the mining industry (red) and the rest (blue) as a function of the mining price index described in Figure 5. The estimated probability of issuance corresponds to the marginal effects implied by the logit regressions reported in Table 10.

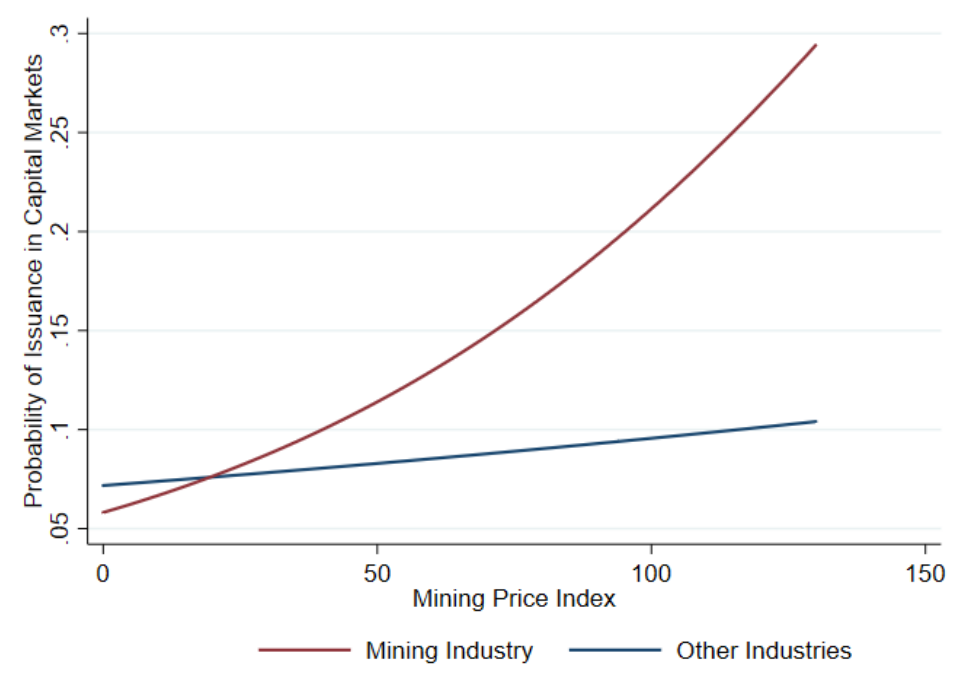


TABLE 1. SUMMARY STATISTICS

This table reports summary statistics characterizing firms' issuance activity (Panel A) and their growth rates (Panel B) over three different periods. The reported firm-level statistics are the median across countries of the median firm per country. For each firm, statistics are first calculated as simple averages over the sample period. The frequency of issuance is calculated as the number of years in which a firm had capital market issuances in a given period over the total number of years that the firm was alive in that period. Issuing firms are those with at least one capital raising issuance within the period analyzed. The table also shows average GDP growth for the median country in the sample.

\section{A. Issuance Activity}

\begin{tabular}{|c|c|c|c|}
\hline & 1991-1999 & $2000-2007$ & $2009-2016$ \\
\hline Total Number of Issuing Firms & 15,436 & 21,845 & 25,126 \\
\hline Frequency of Issuance & $25 \%$ & $29 \%$ & $25 \%$ \\
\hline Capital Raised/Total Assets & $19 \%$ & $23 \%$ & $14 \%$ \\
\hline \multicolumn{4}{|c|}{ B. Growth } \\
\hline & 1991-1999 & $2000-2007$ & $2009-2016$ \\
\hline Asset Growth & $3.8 \%$ & $9.5 \%$ & $1.5 \%$ \\
\hline Issuers & $5.9 \%$ & $15.1 \%$ & $3.8 \%$ \\
\hline Non-issuers & $1.5 \%$ & $7.8 \%$ & $-0.8 \%$ \\
\hline Employment Growth & $1.7 \%$ & $3.7 \%$ & $1.3 \%$ \\
\hline Issuers & $4.3 \%$ & $6.7 \%$ & $2.8 \%$ \\
\hline Non-issuers & $0.2 \%$ & $1.4 \%$ & $0.2 \%$ \\
\hline Sales Growth & $2.8 \%$ & $11.7 \%$ & $0.4 \%$ \\
\hline Issuers & $3.7 \%$ & $14.6 \%$ & $2.3 \%$ \\
\hline Non-issuers & $0.3 \%$ & $9.1 \%$ & $-0.8 \%$ \\
\hline GDP Growth & $2.4 \%$ & $8.3 \%$ & $0.5 \%$ \\
\hline
\end{tabular}


TABLE 2. CAPITAL MARKET FINANCING AND FIRM GROWTH

This table reports difference-in-differences panel regressions of firm-level growth rates on issuance-window dummies. The estimations on firm-level growth rates have different dependent variables: total assets, sales, number of employees, property, plant, and equipment, and intangible assets. The issuance window dummies capture a five-year window around capital raising issuances that took place between 1991 and 2016. Three dummies are included in the regressions: a dummy for the issuance year, a dummy for the pre-issuance years equal to one for the two years preceding the issuance, and a dummy for the post-issuance years equal to one for the two years following the issuance. The table considers three different definitions of issuing firms: both equity and bond issuers (capital market issuers) (Panel A), only equity issuers (Panel B), and only bond issuers (Panel C). For each definition, firms with no issuances are included in the regressions as part of the control group. All regressions include firm and country-year fixed effects. The table reports Wald tests on the differences between the coefficients of the pre-issuance and issuance dummies. The table also reports the average growth of all firms (both issuers and non-issuers) over the entire sample period. Standard errors, shown in brackets, are clustered at the country level. *,**, and $* * *$ denote statistical significance at $10 \%, 5 \%$, and $1 \%$, respectively.

\section{A. Capital Market Issuers}

\begin{tabular}{|c|c|c|c|c|c|}
\hline & Total Assets & Sales & $\begin{array}{l}\text { Number of } \\
\text { Employees }\end{array}$ & $\begin{array}{l}\text { Property, Plant, } \\
\text { and Equipment }\end{array}$ & Intangible Assets \\
\hline \multirow[t]{2}{*}{ Pre-issuance Years } & $5.451 * * *$ & $5.405 * * *$ & $3.872 * * *$ & $6.473 * * *$ & $6.826 * * *$ \\
\hline & [1.187] & {$[0.621]$} & {$[0.633]$} & {$[0.977]$} & {$[0.844]$} \\
\hline \multirow[t]{2}{*}{ Issuance Year } & $19.256 * * *$ & $5.648 * * *$ & $5.938 * * *$ & $10.549 * * *$ & $11.549 * * *$ \\
\hline & {$[2.618]$} & [0.949] & [1.153] & [1.801] & [1.719] \\
\hline \multirow[t]{2}{*}{ Post-issuance Years } & $-2.926 *$ & $1.701 * *$ & $2.021 * * *$ & $3.243 * * *$ & $3.822 * * *$ \\
\hline & [1.652] & {$[0.802]$} & {$[0.359]$} & {$[0.826]$} & [1.201] \\
\hline No. of Observations & 637,503 & 603,145 & 438,453 & 616,423 & 422,995 \\
\hline R-squared & 0.215 & 0.198 & 0.201 & 0.180 & 0.140 \\
\hline \multicolumn{6}{|l|}{ Wald Test: } \\
\hline Issuance vs. Pre-issuance Years & $13.806 * * *$ & 0.244 & $2.067 * * *$ & $4.077 * * *$ & $4.723 * * *$ \\
\hline Average Firm Growth in the Sample (\%) & $7.456 \%$ & $6.497 \%$ & $4.477 \%$ & $5.661 \%$ & $10.094 \%$ \\
\hline
\end{tabular}

B. Equity Issuers

\begin{tabular}{|c|c|c|c|c|c|}
\hline & Total Assets & Sales & $\begin{array}{l}\text { Number of } \\
\text { Employees }\end{array}$ & $\begin{array}{l}\text { Property, Plant, } \\
\text { and Equipment }\end{array}$ & Intangible Assets \\
\hline \multirow[t]{2}{*}{ Pre-issuance Years } & $5.763 * * *$ & $5.723 * * *$ & $3.876 * * *$ & $6.791 * * *$ & $7.099 * * *$ \\
\hline & {$[1.279]$} & {$[0.699]$} & {$[0.537]$} & {$[1.000]$} & {$[0.912]$} \\
\hline \multirow[t]{2}{*}{ Issuance Year } & $21.693 * * *$ & $6.421 * * *$ & $6.620 * * *$ & $11.616 * * *$ & $12.203 * * *$ \\
\hline & {$[2.797]$} & [1.125] & [1.171] & [1.910] & [1.672] \\
\hline \multirow[t]{2}{*}{ Post-issuance Years } & -1.971 & $2.717 * * *$ & $2.768 * * *$ & $4.471 * * *$ & $5.751 * * *$ \\
\hline & {$[1.604]$} & {$[0.827]$} & {$[0.471]$} & {$[0.901]$} & {$[1.281]$} \\
\hline No. of Observations & 637,503 & 603,145 & 438,453 & 616,423 & 422,995 \\
\hline R-squared & 0.216 & 0.199 & 0.201 & 0.180 & 0.140 \\
\hline \multicolumn{6}{|l|}{ Wald Test: } \\
\hline Issuance vs. Pre-issuance Years & $15.930 * * *$ & 0.698 & $2.744 * * *$ & $4.825 * * *$ & $5.105 * * *$ \\
\hline \multicolumn{6}{|c|}{ C. Bond Issuers } \\
\hline \multirow{3}{*}{ Pre-issuance Years } & Total Assets & Sales & $\begin{array}{l}\text { Number of } \\
\text { Employees }\end{array}$ & $\begin{array}{l}\text { Property, Plant, } \\
\text { and Equipment }\end{array}$ & Intangible Assets \\
\hline & $3.760 * * *$ & $2.824 * * *$ & $2.661 * * *$ & $4.249^{* * *}$ & $4.616^{* * *}$ \\
\hline & {$[0.517]$} & {$[0.276]$} & {$[0.586]$} & {$[0.601]$} & {$[0.630]$} \\
\hline \multirow[t]{2}{*}{ Issuance Year } & $7.680 * * *$ & $2.949 * * *$ & $3.552 * * *$ & $5.406 * * *$ & $8.603 * * *$ \\
\hline & [1.615] & {$[0.608]$} & [1.010] & [1.010] & [2.195] \\
\hline \multirow[t]{2}{*}{ Post-issuance Years } & $-3.691 * * *$ & $-0.965 *$ & -0.799 & $-2.116 * *$ & $-3.317 * *$ \\
\hline & {$[1.306]$} & {$[0.572]$} & [0.569] & {$[0.983]$} & {$[1.425]$} \\
\hline No. of Observations & 637,503 & 603,145 & 438,453 & 616,423 & 422,995 \\
\hline R-squared & 0.199 & 0.196 & 0.197 & 0.176 & 0.139 \\
\hline \multicolumn{6}{|l|}{ Wald Test: } \\
\hline Issuance vs. Pre-issuance Years & $3.920 * * *$ & 0.125 & 0.891 & $1.157 *$ & 3.987 ** \\
\hline
\end{tabular}




\section{TABLE 3. CAPITAL MARKET FINANCING AND FIRM GROWTH ACROSS INDUSTRIES}

This table reports difference-in-differences panel regressions of firm-level growth rates on issuance-window dummies. Separate regressions are estimated for firms in each one-digit SIC industry. The estimations on firm-level growth rates have different dependent variables: total assets, sales, number of employees, property, plant, and equipment, and intangible assets. The issuance window dummies capture a five-year window around capital raising issuances that took place between 1991 and 2016. Three dummies are included in the regressions: a dummy for the issuance vear, a dummy for the pre-issuance years equal to one for the two years preceding the issuance, and a dummy for the postissuance years equal to one for the two years following the issuance. Firms with no issuances are also included in the regressions as part of the control group. All regressions include firm and country-year fixed effects. The table also reports Wald tests on the differences between the coefficients of the pre-issuance and issuance dummies. Standard errors, shown in brackets, are clustered at the country level. *, **, and $* * *$ denote statistical significance at $10 \%, 5 \%$, and $1 \%$, respectively.

A. Total Assets

\section{Pre-issuance Years}

Issuance Year

Post-issuance Years

No. of Observations

R-squared

Wald Test:

Issuance vs. Pre-issuance Years
Agriculture,

Forestry, and

$\frac{\text { Fisbing }}{6.981^{* * *}}$

[1.990]

$20.260 * * *$

[3.720]

0.021

[1.552]

7,126

0.321

$13.279^{* * *}$

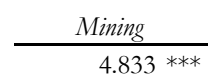

$[1.314]$

$29.605 * * *$

[5.605]

$-6.560$

[4.249]

56,577

0.221

$24.773 * * *$

Construction

$3.956^{* * *} \frac{\text { Manufacturing }}{3.985^{* * *}}$

$[0.887]$

$11.705 * * *$

[1.536]

1.408

[0.883]

31,879

0.334

7.749 ***

B. Sales

\begin{tabular}{|c|c|c|c|c|c|c|c|c|}
\hline & $\begin{array}{l}\text { Agriculture, } \\
\text { Forestry, and } \\
\text { Fisbing } \\
\end{array}$ & Mining & Construction & Manufacturing & $\begin{array}{l}\text { Transportation, } \\
\text { Communications, } \\
\text { Electric, Gas, and } \\
\text { Sanitary Services } \\
\end{array}$ & Wholesale Trade & Retail Trade & Services \\
\hline Pre-issuance Years & $\begin{array}{l}10.356 * * * \\
{[1.959]}\end{array}$ & $\begin{array}{l}3.442 * \\
{[2.002]}\end{array}$ & $\begin{array}{l}6.155^{* * *} \\
{[1.138]}\end{array}$ & $\begin{array}{l}4.602 \text { *** } \\
{[0.620]}\end{array}$ & $\begin{array}{c}4.615 \text { *** } \\
{[0.795]}\end{array}$ & $\begin{array}{l}5.377 \text { *** } \\
{[1.311]}\end{array}$ & $\begin{array}{l}3.336 * * * \\
{[0.896]}\end{array}$ & $\begin{array}{l}6.764 \text { *** } \\
{[1.178]}\end{array}$ \\
\hline Issuance Year & $\begin{array}{l}5.861 * * * \\
{[1.964]}\end{array}$ & $\begin{array}{r}1.961 \\
{[5.013]}\end{array}$ & $\begin{array}{l}4.438 * * * \\
{[0.885]}\end{array}$ & $\begin{array}{l}4.533 \text { *** } \\
{[0.773]}\end{array}$ & $\begin{array}{l}5.619 \text { *** } \\
{[0.998]}\end{array}$ & $\begin{array}{l}4.969 * * * \\
{[0.873]}\end{array}$ & $\begin{array}{l}4.362 \text { *** } \\
{[0.839]}\end{array}$ & $\begin{array}{l}8.866 * * * \\
{[1.499]}\end{array}$ \\
\hline Post-issuance Years & $\begin{array}{l}3.208 * \\
{[1.752]}\end{array}$ & $\begin{array}{r}6.390 \\
{[3.851]}\end{array}$ & $\begin{array}{r}1.192 \\
{[1.096]}\end{array}$ & $\begin{array}{r}0.631 \\
{[0.530]}\end{array}$ & $\begin{array}{l}1.170 \text { ** } \\
{[0.493]}\end{array}$ & $\begin{array}{r}1.953 \\
{[1.205]}\end{array}$ & $\begin{array}{l}2.145 * * \\
{[0.816]}\end{array}$ & $\begin{array}{l}2.152 * * \\
{[1.066]}\end{array}$ \\
\hline $\begin{array}{l}\text { No. of Observations } \\
\text { R-squared }\end{array}$ & $\begin{array}{l}6,901 \\
0.272\end{array}$ & $\begin{array}{r}36,349 \\
0.192\end{array}$ & $\begin{array}{r}31,471 \\
0.194\end{array}$ & $\begin{array}{r}296,855 \\
0.213\end{array}$ & $\begin{array}{r}57,986 \\
0.243\end{array}$ & $\begin{array}{r}31,344 \\
0.226\end{array}$ & $\begin{array}{r}35,965 \\
0.292\end{array}$ & $\begin{array}{r}105,148 \\
0.221\end{array}$ \\
\hline Wald Test: & & & & & & & & \\
\hline Issuance vs. Pre-issuance Years & $-4.495 * *$ & -1.481 & -1.717 & -0.069 & $1.004 *$ & -0.408 & 1.026 & $2.103 * * *$ \\
\hline
\end{tabular}

Transportation,

Communications

Electric, Gas, and

$\frac{\text { Sanitary Services }}{5.074^{* * *}}$

[0.848] [1.511]

16.909 ***

[2.853]

$-2.514 *$

12.753 ***

[1.189]

[1.439]

$-3.415 * * *$

[1.205]

303,241

59,265

0.229

Wholesale Trade

[1.006]

13.379 ***

[2.406]

$11.397 * * *$

[2.228]

$\begin{array}{cc}1.479 * * & -0.307 \\ {[0.616]} & {[0.654]}\end{array}$

31,714

36,116

0.275

0.245

$12.924 * * *$

$7.680 * * *$

8.914 ***

$7.955 * * *$

$16.171 * * *$

23.914 ***

[2.385]

$-4.820 * *$

[2.341]

$171 * * *$


TABLE 3. CAPITAL MARKET FINANCING AND FIRM GROWTH ACROSS INDUSTRIES

D. Number of Employees

\begin{tabular}{|c|c|c|c|c|c|c|c|c|}
\hline \multicolumn{9}{|c|}{ D. Number of Employees } \\
\hline & $\begin{array}{l}\text { Agriculture, } \\
\text { Forestry, and } \\
\text { Fishing }\end{array}$ & Mining & Construction & Manufacturing & $\begin{array}{l}\text { Transportation, } \\
\text { Communications, } \\
\text { Electric, Gas, and } \\
\text { Sanitary Services }\end{array}$ & Wholesale Trade & Retail Trade & Services \\
\hline Pre-issuance Years & $\begin{array}{c}4.931 * \\
{[2.668]}\end{array}$ & $\begin{array}{l}4.555 \text { *** } \\
{[1.192]}\end{array}$ & $\begin{array}{c}1.809 \text { ** } \\
{[0.712]}\end{array}$ & $\begin{array}{l}3.170 \text { *** } \\
{[0.588]}\end{array}$ & $\begin{array}{c}4.297 \text { *** } \\
{[1.039]}\end{array}$ & $\begin{array}{c}2.711^{* *} \\
{[1.182]}\end{array}$ & $\begin{array}{l}2.906 * * * \\
{[0.848]}\end{array}$ & $\begin{array}{l}5.090 \text { *** } \\
{[0.616]}\end{array}$ \\
\hline Issuance Year & $\begin{array}{l}7.231 \\
{[1.831]}\end{array}$ & $\begin{array}{l}7.972 \text { *** } \\
{[0.993]}\end{array}$ & $\begin{array}{l}4.396 \text { *** } \\
{[1.240]}\end{array}$ & $\begin{array}{l}4.825 \text { *** } \\
{[1.067]}\end{array}$ & $\begin{array}{l}5.328 * * * \\
{[1.076]}\end{array}$ & $\begin{array}{l}4.900 \text { *** } \\
{[1.624]}\end{array}$ & $\begin{array}{l}3.335 * * * \\
{[1.222]}\end{array}$ & $\begin{array}{l}8.578 * * * \\
{[1.492]}\end{array}$ \\
\hline Post-issuance Years & $\begin{array}{l}5.054 * * * \\
{[1.488]}\end{array}$ & $\begin{array}{l}1.892 \text { ** } \\
{[0.908]}\end{array}$ & $\begin{array}{l}1.992 * * * \\
{[0.661]}\end{array}$ & $\begin{array}{l}1.508 \text { *** } \\
{[0.386]}\end{array}$ & $\begin{array}{l}1.117 \text { ** } \\
{[0.467]}\end{array}$ & $\begin{array}{l}3.152 \text { *** } \\
{[0.938]}\end{array}$ & $\begin{array}{l}2.186 \text { ** } \\
{[0.849]}\end{array}$ & $\begin{array}{l}3.076 \text { *** } \\
{[0.418]}\end{array}$ \\
\hline No. of Observations & 3,384 & 21,408 & 21,274 & 218,016 & 42,046 & 23,378 & 28,673 & 78,834 \\
\hline R-squared & 0.332 & 0.237 & 0.191 & 0.201 & 0.217 & 0.209 & 0.234 & 0.233 \\
\hline Wald Test: & & & & & & & & \\
\hline $\begin{array}{c}\text { Issuance vs. Pre-issuance Years } \\
\end{array}$ & 2.300 & $3.417 * * *$ & $2.587 * *$ & $1.655 * * *$ & $1.032 *$ & $2.189 * * *$ & 0.429 & $3.488 * * *$ \\
\hline \multicolumn{9}{|c|}{ E. Property, Plant, and Equipment } \\
\hline & $\begin{array}{c}\text { Agriculture, } \\
\text { Forestry, and } \\
\text { Fishing } \\
\end{array}$ & Mining & Construction & Manufacturing & $\begin{array}{l}\text { Transportation, } \\
\text { Communications, } \\
\text { Electric, Gas, and } \\
\text { Sanitary Services } \\
\end{array}$ & Wholesale Trade & Retail Trade & Services \\
\hline Pre-issuance Years & $\begin{array}{c}7.921 \text { *** } \\
{[1.898]}\end{array}$ & $\begin{array}{l}12.187 \text { *** } \\
{[1.368]}\end{array}$ & $\begin{array}{l}4.768 * * * \\
{[1.471]}\end{array}$ & $\begin{array}{l}4.550 * * * \\
{[0.687]}\end{array}$ & $\begin{array}{c}5.590 * * * \\
{[1.295]}\end{array}$ & $\begin{array}{c}4.405 \text { *** } \\
{[1.621]}\end{array}$ & $\begin{array}{c}4.293 * * * \\
{[0.867]}\end{array}$ & $\begin{array}{l}7.217 \text { *** } \\
{[1.351]}\end{array}$ \\
\hline Issuance Year & $\begin{array}{l}14.691 \text { *** } \\
{[3.276]}\end{array}$ & $\begin{array}{l}21.172 * * * \\
{[4.355]}\end{array}$ & $\begin{array}{l}8.109 * * * \\
{[1.714]}\end{array}$ & $\begin{array}{l}7.244 \text { *** } \\
{[1.127]}\end{array}$ & $\begin{array}{l}9.533 \text { *** } \\
{[1.415]}\end{array}$ & $\begin{array}{l}8.200 * * * \\
{[1.707]}\end{array}$ & $\begin{array}{l}6.592{ }^{* * *} \\
{[1.875]}\end{array}$ & $\begin{array}{l}11.646 \text { *** } \\
{[2.376]}\end{array}$ \\
\hline Post-issuance Years & $\begin{array}{l}4.724 \text { ** } \\
{[1.929]}\end{array}$ & $\begin{array}{l}-1.338 \\
{[2.164]}\end{array}$ & $\begin{array}{l}4.112 \text { *** } \\
{[0.981]}\end{array}$ & $\begin{array}{l}3.843 \text { *** } \\
{[0.927]}\end{array}$ & $\begin{array}{r}1.276 \\
{[0.834]}\end{array}$ & $\begin{array}{l}5.748 \text { *** } \\
{[1.564]}\end{array}$ & $\begin{array}{l}2.806 \text { *** } \\
{[0.543]}\end{array}$ & $\begin{array}{l}3.506 \text { *** } \\
{[0.709]}\end{array}$ \\
\hline No. of Observations & 6,909 & 51,028 & 31,253 & 297,518 & 57,704 & 30,903 & 35,359 & 104,632 \\
\hline R-squared & 0.281 & 0.182 & 0.187 & 0.200 & 0.216 & 0.184 & 0.239 & 0.197 \\
\hline Wald Test: & & & & & & & & \\
\hline Issuance vs. Pre-issuance Years & $6.769 * *$ & $8.985 * * *$ & $3.341 * *$ & $2.694 * * *$ & $3.943 * * *$ & $3.794 * * *$ & 2.299 & $4.429 * * *$ \\
\hline \multicolumn{9}{|c|}{ F. Intangible Assets } \\
\hline & $\begin{array}{l}\text { Agriculture, } \\
\text { Forestry, and } \\
\text { Fisbing }\end{array}$ & Mining & Construction & Manufacturing & $\begin{array}{l}\text { Transportation, } \\
\text { Communications, } \\
\text { Electric, Gas, and } \\
\text { Sanitary Services }\end{array}$ & Wholesale Trade & Retail Trade & Services \\
\hline Pre-issuance Years & $\begin{array}{l}10.013 * \\
{[5.065]}\end{array}$ & $\begin{array}{l}8.976^{* * *} \\
{[2.477]}\end{array}$ & $\begin{array}{l}7.184 * * * \\
{[2.072]}\end{array}$ & $\begin{array}{c}5.573 \text { *** } \\
{[0.900]}\end{array}$ & $\begin{array}{c}.518 * * * \\
{[1.092]}\end{array}$ & $\begin{array}{c}6.259 \text { *** } \\
{[2.217]}\end{array}$ & $\begin{array}{l}3.318 * * * \\
{[1.136]}\end{array}$ & $\begin{array}{l}8.587 \text { *** } \\
{[1.313]}\end{array}$ \\
\hline Issuance Year & $\begin{array}{l}11.316 * \\
{[6.205]}\end{array}$ & $\begin{array}{l}11.630 * * * \\
{[2.230]}\end{array}$ & $\begin{array}{l}8.037 * * * \\
{[2.873]}\end{array}$ & $\begin{array}{l}9.938 \text { *** } \\
{[1.502]}\end{array}$ & $\begin{array}{l}10.717 \text { *** } \\
{[1.934]}\end{array}$ & $\begin{array}{l}9.764 * * * \\
{[2.968]}\end{array}$ & $\begin{array}{l}7.001 * * * \\
{[2.517]}\end{array}$ & $\begin{array}{l}16.425 \text { *** } \\
{[2.446]}\end{array}$ \\
\hline Post-issuance Years & $\begin{array}{l}13.632 \text { *** } \\
{[4.443]}\end{array}$ & $\begin{array}{l}-1.195 \\
{[2.707]}\end{array}$ & $\begin{array}{l}4.470 * * \\
{[1.676]}\end{array}$ & $\begin{array}{l}3.246 \text { ** } \\
{[1.427]}\end{array}$ & $\begin{array}{l}-2.607 * \\
{[1.510]}\end{array}$ & $\begin{array}{l}8.125 \text { *** } \\
{[2.105]}\end{array}$ & $\begin{array}{r}0.982 \\
{[1.814]}\end{array}$ & $\begin{array}{l}8.273 \text { *** } \\
{[1.584]}\end{array}$ \\
\hline No. of Observations & 3,913 & 14,078 & 20,455 & 215,960 & 40,227 & 22,332 & 26,604 & 78,108 \\
\hline R-squared & 0.296 & 0.224 & 0.181 & 0.135 & 0.171 & 0.174 & 0.187 & 0.182 \\
\hline Wald Test: & & & & & & & & \\
\hline Issuance vs. Pre-issuance Years & 1.303 & 2.654 & 0.852 & $4.365 * * *$ & 2.198 & 3.505 & 3.683 & $7.837 * * *$ \\
\hline
\end{tabular}


TABLE 4. GROWTH OF SMALL FIRMS

This table reports difference-in-differences panel regressions of firm-level growth rates on issuance-window dummies for small versus large firms. The estimations on firm-level growth rates have different dependent variables: total assets, sales, number of employees, property, plant, and equipment, and intangible assets. The regressions include three dummies to capture a five-year issuance window: a dummy for the issuance year, a dummy for the pre-issuance years equal to one for the two years preceding the issuance, and a dummy for the post-issuance years equal to one for the two years following the issuance. These dummies consider issuances that took place between 1991 and 2016. Interaction terms between these issuance dummies and a small-firm dummy are also included in the regressions. Firms are classified as small if the value of their total assets is in the bottom 75 th percentile of all sampled firms in a given country and year. The definition of small firms can vary within firms over time. The table considers three different definitions of issuing firms: both equity and bond issuers (capital market issuers) (Panel A), only equity issuers (Panel B), and only bond issuers (Panel C). For each definition, firms with no issuances are included in the regressions as part of the control group. All regressions include firm and country-year fixed effects. Standard errors, shown in brackets, are clustered at the country level. *, **, and *** denote statistical significance at $10 \%$, $5 \%$, and $1 \%$, respectively.

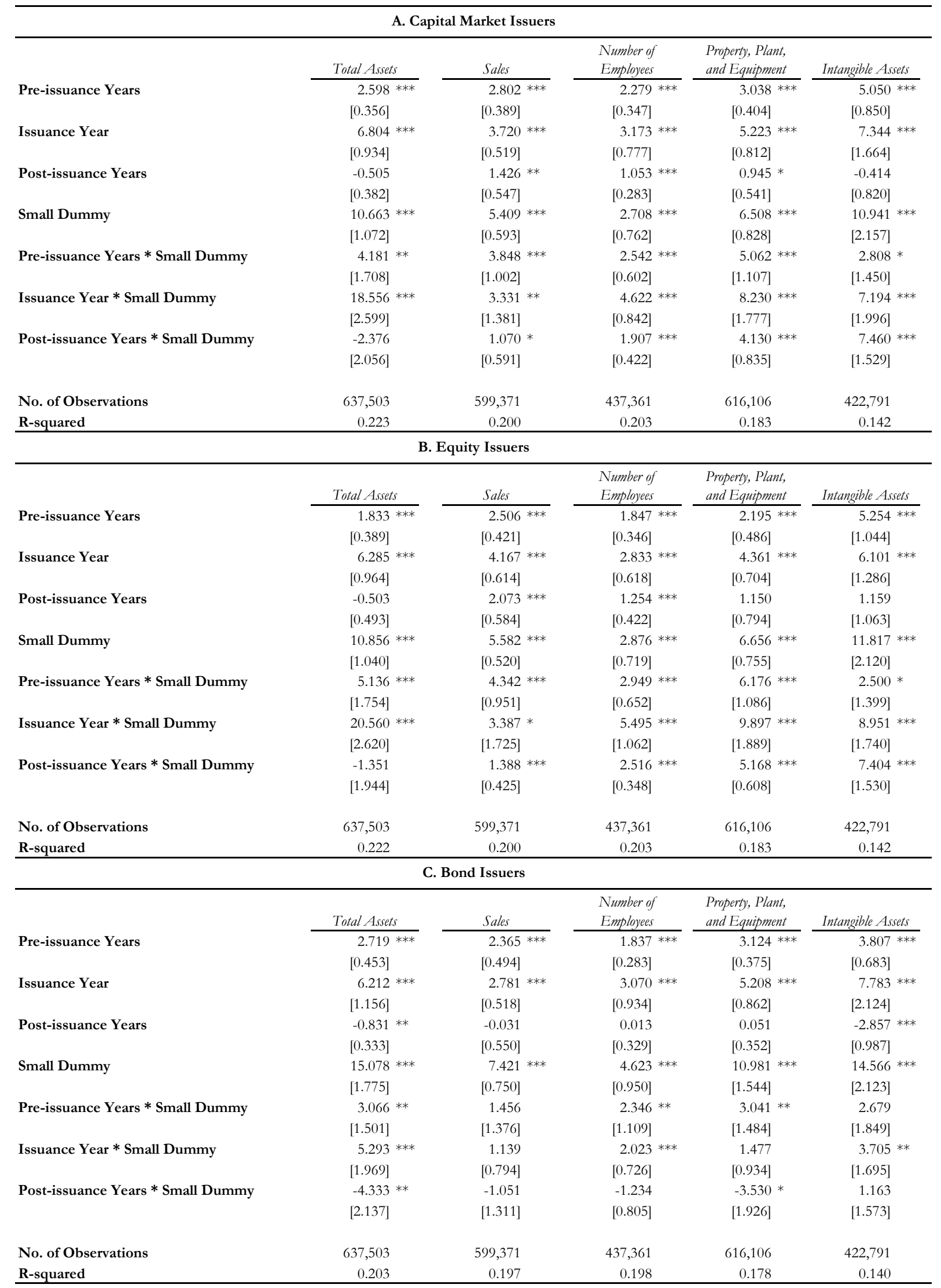




\section{TABLE 5. GROWTH OF YOUNG FIRMS}

This table reports difference-in-differences panel regressions of firm-level growth rates on issuance-window dummies for young versus old firms. The estimations on firm level growth rates have different dependent variables: total assets, sales, number of employees, property, plant, and equipment, and intangible assets. The regressions include three dummies to capture a five-year issuance window: a dummy for the issuance year, a dummy for the pre-issuance years equal to one for the two years preceding the issuance, and a dummy for the post-issuance years equal to one for the two years following the issuance. These dummies consider issuances that took place between 1991 and 2016. Interaction terms between these issuance dummies and a young-firm dummy are also included in the regressions. Firms are classified as young if they are younger than 15 years. The definition of young firms varies within firms over time. The table considers three different definitions of issuing firms: both equity and bond issuers (capital market issuers) (Panel A), only equity issuers (Panel B), and only bond issuers (Panel C). For each definition, firms with no issuances are included in the regressions as part of the control group. All regressions include firm and country-year fixed effects. Standard errors, shown in brackets, are clustered at the country level. $*$, **, and $* * *$ denote statistical significance at $10 \%, 5 \%$, and $1 \%$, respectively.

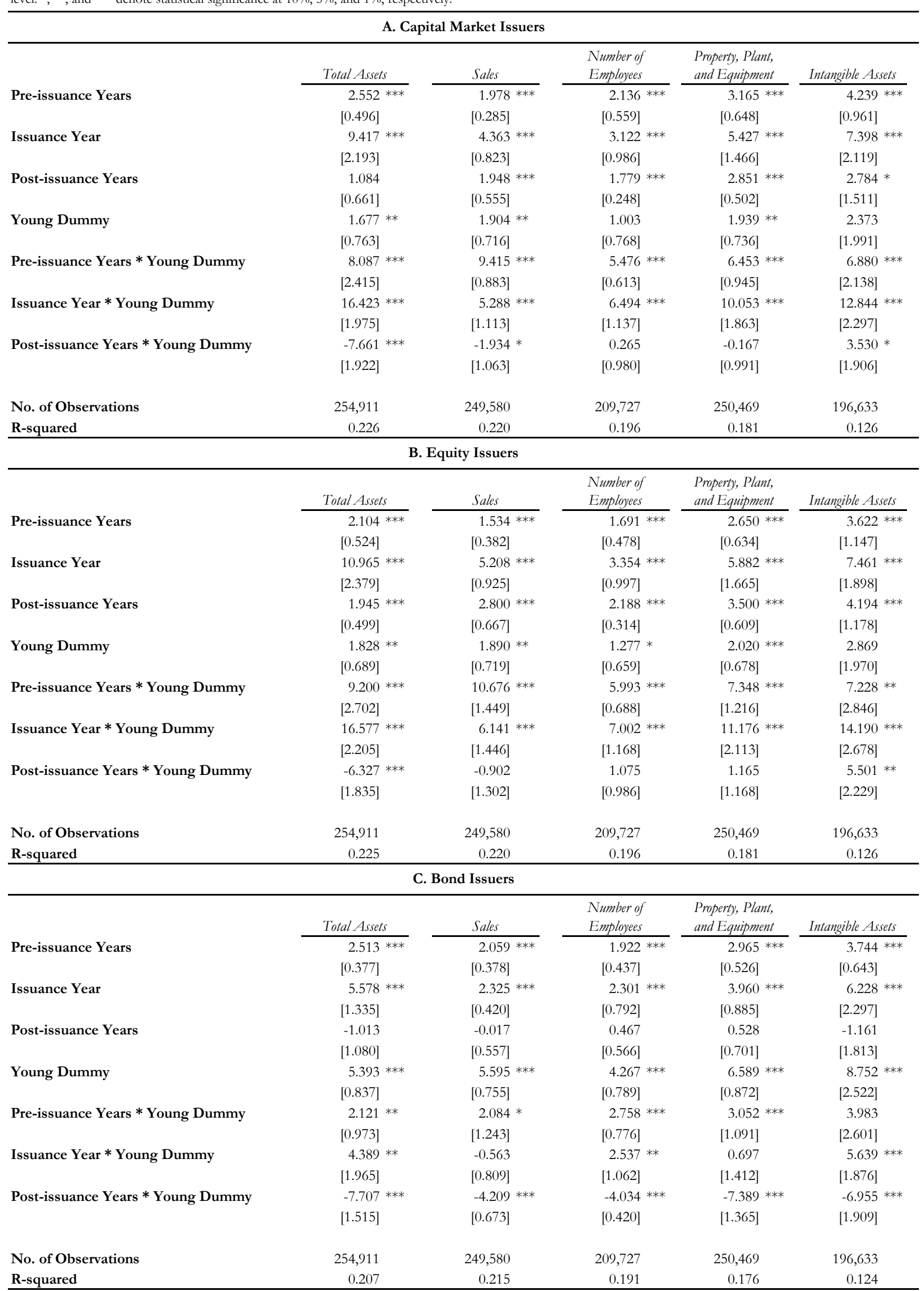




\section{TABLE 6. GROWTH OF SMALL AND YOUNG FIRMS}

This table reports difference-in-differences panel regressions of firm-level growth rates on issuance-window dummies for small and young firms versus large and old firms. The estimations on firm-level growth rates have different dependent variables: total assets, sales, number of employees, property, plant, and equipment, and intangible assets. The regressions include three dummies to capture a five-year issuance window: a dummy for the issuance year, a dummy for the pre-issuance years equal to one for the two years preceding the issuance, and a dummy for the post-issuance years equal to one for the two years following the issuance. These dummies consider issuances that took place between 1991 and 2016. Interaction terms between these issuance dummies and both a small-firm dummy and a young-firm dummy are also included in the regressions. Firms are classified as small if the value of their total assets is in the bottom 75 th percentile of all sampled firms in a given country and year. Firms are classified as young if they are younger than 15 years. The definition of small and young firms can vary within firms over time. Firms with no issuances are also included in the regressions as part of the control group. All regressions include firm and country-year fixed effects. Standard errors, shown in brackets, are clustered at the country level. *, **, and *** denote statistical significance at $10 \%, 5 \%$, and $1 \%$, respectively.

\begin{tabular}{|c|c|c|c|c|c|}
\hline & Total Assets & Sales & $\begin{array}{l}\text { Number of } \\
\text { Employees }\end{array}$ & $\begin{array}{l}\text { Property, Plant, } \\
\text { and Equipment }\end{array}$ & Intangible Assets \\
\hline \multirow[t]{2}{*}{ Pre-issuance Years } & $1.120^{* *}$ & $0.970 * *$ & $1.356^{* * *}$ & $1.984^{* * *}$ & $3.072 * * *$ \\
\hline & {$[0.485]$} & {$[0.392]$} & {$[0.391]$} & {$[0.446]$} & {$[0.774]$} \\
\hline \multirow[t]{2}{*}{ Issuance Year } & $3.184 * * *$ & $2.564 * * *$ & $1.438 * *$ & $2.386 * * *$ & $4.535 * * *$ \\
\hline & {$[1.066]$} & {$[0.651]$} & {$[0.661]$} & {$[0.800]$} & {$[1.575]$} \\
\hline \multirow[t]{2}{*}{ Post-issuance Years } & $1.009 * * *$ & $0.939 *$ & $0.855 * * *$ & $0.984 * * *$ & -0.897 \\
\hline & {$[0.301]$} & {$[0.476]$} & {$[0.283]$} & {$[0.299]$} & {$[1.021]$} \\
\hline \multirow[t]{2}{*}{ Small Dummy } & $7.340 * * *$ & $3.741 * * *$ & $2.357 * * *$ & $4.696 * * *$ & $8.450 * * *$ \\
\hline & {$[0.969]$} & {$[0.485]$} & {$[0.677]$} & {$[0.794]$} & [2.058] \\
\hline \multirow[t]{2}{*}{ Pre-issuance Years * Small Dummy } & $2.467 *$ & $1.777 *$ & $1.394 * *$ & $2.029 *$ & 1.975 \\
\hline & {$[1.466]$} & {$[0.886]$} & {$[0.548]$} & {$[1.068]$} & {$[1.541]$} \\
\hline \multirow[t]{2}{*}{ Issuance Year * Small Dummy } & $11.938 * * *$ & $3.523 * * *$ & $3.419 * * *$ & $5.897 * * *$ & $5.792 * *$ \\
\hline & {$[3.057]$} & {$[0.781]$} & {$[1.001]$} & [1.901] & {$[2.501]$} \\
\hline \multirow[t]{2}{*}{ Post-issuance Years * Small Dummy } & 0.640 & $2.008 * * *$ & $1.775 * * *$ & $3.511 * * *$ & $6.858 * * *$ \\
\hline & [1.132] & {$[0.573]$} & {$[0.408]$} & {$[0.688]$} & {$[2.078]$} \\
\hline \multirow[t]{2}{*}{ Young Dummy } & $1.963 * * *$ & $1.950 * * *$ & 1.133 & $2.180 * * *$ & 2.628 \\
\hline & {$[0.682]$} & {$[0.675]$} & {$[0.722]$} & {$[0.695]$} & {$[1.918]$} \\
\hline \multirow[t]{2}{*}{ Pre-issuance Years * Young Dummy } & $7.528 * * *$ & $9.140 * * *$ & $5.206 * * *$ & $6.057 * * *$ & $6.585 * * *$ \\
\hline & {$[2.084]$} & {$[0.731]$} & {$[0.726]$} & {$[0.881]$} & {$[2.219]$} \\
\hline \multirow[t]{2}{*}{ Issuance Year * Young Dummy } & $13.662 * * *$ & $4.707 * * *$ & $5.667 * * *$ & $8.701 * * *$ & $11.654 * * *$ \\
\hline & {$[1.980]$} & {$[1.074]$} & {$[1.107]$} & {$[1.816]$} & {$[2.465]$} \\
\hline \multirow[t]{2}{*}{ Post-issuance Years * Young Dummy } & $-7.626 * * *$ & $-2.141 *$ & 0.037 & -0.676 & 2.459 \\
\hline & {$[1.744]$} & {$[1.146]$} & {$[0.943]$} & {$[1.016]$} & {$[1.848]$} \\
\hline No. of Observations & 254,911 & 248,973 & 209,538 & 250,425 & 196,597 \\
\hline R-squared & 0.232 & 0.222 & 0.198 & 0.183 & 0.127 \\
\hline
\end{tabular}


TABLE 7. GROWTH OF HIGH-R\&D FIRMS

This table reports difference-in-differences panel regressions of firm-level growth rates on issuance-window dummies for high- versus low-R\&D firms. The estimations on firm-level growth rates have different dependent variables: total assets, sales, number of employees, property, plant, and equipment, and intangible assets. The regressions include three dummies to capture a five-year issuance window: a dummy for the issuance year, a dummy for the pre-issuance years equal to one for the two years preceding the issuance, and a dummy for the post-issuance years equal to one for the two years following the issuance. These dummies consider issuances that took place between 1991 and 2016. Interaction terms between these issuance dummies and a high-R\&D-firm dummy are also included in the regressions. The high-R\&D classification is at the industry level. All firms in a two-digit SIC industry code are classified as high-R\&D firms if the median firm in that industry in the U.S. has a ratio of R\&D to total investments greater than 0.6. The table considers three different definitions of issuing firms: both equity and bond issuers (capital market issuers) (Panel A), only equity issuers (Panel B), and only bond issuers (Panel C). For each definition, firms with no issuances are included in the regressions as part of the control group. All regressions include firm and country-year fixed effects. Standard errors, shown in brackets, are clustered at the country level. *, **, and $* * *$ denote statistical significance at $10 \%, 5 \%$, and $1 \%$, respectively.

\section{A. Capital Market Issuers}

\begin{tabular}{|c|c|c|c|c|c|}
\hline & Total Assets & Sales & $\begin{array}{l}\text { Number of } \\
\text { Employees }\end{array}$ & $\begin{array}{l}\text { Property, Plant, } \\
\text { and Equipment }\end{array}$ & Intangible Assets \\
\hline \multirow[t]{2}{*}{ Pre-issuance Years } & $5.213 * * *$ & $5.304 * * *$ & $3.487 * * *$ & $6.863 * * *$ & $6.614^{* * *}$ \\
\hline & {$[0.852]$} & {$[0.608]$} & {$[0.675]$} & {$[1.239]$} & {$[0.936]$} \\
\hline \multirow[t]{2}{*}{ Issuance Year } & $16.908 * * *$ & $4.908 * * *$ & $5.170 * * *$ & $10.901 * * *$ & $10.350 * * *$ \\
\hline & {$[2.846]$} & {$[0.883]$} & {$[1.050]$} & {$[2.170]$} & [1.739] \\
\hline \multirow[t]{2}{*}{ Post-issuance Years } & -1.538 & $2.316 * *$ & $2.007 * * *$ & $2.702 * * *$ & $2.135 *$ \\
\hline & {$[1.429]$} & {$[0.920]$} & {$[0.409]$} & {$[0.907]$} & {$[1.186]$} \\
\hline \multirow[t]{2}{*}{ Pre-issuance Years * High-R\&D Dummy } & 0.713 & 0.275 & $0.950 * * *$ & -1.011 & 0.565 \\
\hline & {$[1.287]$} & {$[0.507]$} & {$[0.276]$} & {$[1.160]$} & {$[0.699]$} \\
\hline \multirow[t]{2}{*}{ Issuance Year * High-R\&D Dummy } & $6.187 * *$ & $1.884 * *$ & $1.874 * * *$ & -0.930 & $2.890 * *$ \\
\hline & {$[2.390]$} & {$[0.848]$} & {$[0.436]$} & {$[1.933]$} & {$[1.183]$} \\
\hline \multirow[t]{2}{*}{ Post-issuance Years * High-R\&D Dummy } & $-3.421 * *$ & $-1.497 * *$ & 0.074 & $1.337 * *$ & $3.944 * * *$ \\
\hline & {$[1.617]$} & {$[0.626]$} & {$[0.339]$} & {$[0.636]$} & {$[0.945]$} \\
\hline No. of Observations & 637,392 & 603,071 & 438,409 & 616,344 & 422,973 \\
\hline R-squared & 0.216 & 0.199 & 0.201 & 0.180 & 0.141 \\
\hline
\end{tabular}

\begin{tabular}{lrr} 
R-squared & 0.216 & 0.199 \\
\hline & B. Equity Issuers
\end{tabular}

\begin{tabular}{|c|c|c|c|c|c|}
\hline & Total Assets & Sales & $\begin{array}{l}\text { Number of } \\
\text { Employees }\end{array}$ & $\begin{array}{l}\text { Property, Plant, } \\
\text { and Equipment }\end{array}$ & Intangible Assets \\
\hline \multirow[t]{2}{*}{ Pre-issuance Years } & $5.323 * * *$ & $5.386 * * *$ & $3.323 * * *$ & $7.143 * * *$ & $6.743 * * *$ \\
\hline & [0.839] & [0.635] & {$[0.546]$} & {$[1.327]$} & {$[1.059]$} \\
\hline \multirow[t]{2}{*}{ Issuance Year } & $19.101 * * *$ & $5.418 * * *$ & $5.565 * * *$ & $11.884 * * *$ & $10.830 * * *$ \\
\hline & {$[3.163]$} & [1.086] & [1.018] & {$[2.358]$} & {$[1.692]$} \\
\hline \multirow[t]{2}{*}{ Post-issuance Years } & -0.502 & $3.523 * * *$ & $2.707 * * *$ & $3.830 * * *$ & $3.871 * * *$ \\
\hline & [1.458] & {$[0.974]$} & {$[0.519]$} & [1.043] & {$[1.306]$} \\
\hline \multirow[t]{2}{*}{ Pre-issuance Years * High-R\&D Dummy } & 1.212 & 0.859 & $1.324 * * *$ & -0.895 & 0.860 \\
\hline & {$[1.478]$} & {$[0.539]$} & {$[0.286]$} & {$[1.361]$} & {$[0.868]$} \\
\hline \multirow[t]{2}{*}{ Issuance Year * High-R\&D Dummy } & $6.676 * *$ & $2.483 *$ & $2.446 * * *$ & -0.685 & $3.161 * *$ \\
\hline & {$[2.708]$} & {$[1.298]$} & [0.639] & [2.295] & {$[1.450]$} \\
\hline \multirow[t]{2}{*}{ Post-issuance Years * High-R\&D Dummy } & $-3.631 * *$ & $-1.956 * * *$ & 0.177 & $1.597 * *$ & $4.347 * * *$ \\
\hline & {$[1.729]$} & {$[0.674]$} & {$[0.409]$} & {$[0.679]$} & {$[1.282]$} \\
\hline No. of Observations & 637,392 & 603,071 & 438,409 & 616,344 & 422,973 \\
\hline R-squared & 0.216 & 0.199 & 0.201 & 0.180 & 0.140 \\
\hline \multicolumn{6}{|c|}{ C. Bond Issuers } \\
\hline \multirow{3}{*}{ Pre-issuance Years } & Total Assets & Sales & $\begin{array}{l}\text { Number of } \\
\text { Employees }\end{array}$ & $\begin{array}{l}\text { Property, Plant, } \\
\text { and Equipment }\end{array}$ & Intangible Assets \\
\hline & $4.537 * * *$ & $3.322 * * *$ & $2.804 * * *$ & $4.948^{* * *}$ & $5.414^{* * *}$ \\
\hline & {$[0.638]$} & {$[0.331]$} & {$[0.693]$} & {$[0.688]$} & {$[0.818]$} \\
\hline \multirow[t]{2}{*}{ Issuance Year } & $7.325 * * *$ & $3.371 * * *$ & $3.877 * * *$ & $6.123 * * *$ & $8.435 * * *$ \\
\hline & {$[1.480]$} & {$[0.703]$} & {$[1.084]$} & {$[1.162]$} & {$[2.102]$} \\
\hline \multirow[t]{2}{*}{ Post-issuance Years } & $-3.166 * * *$ & -0.793 & -0.401 & $-1.730 * *$ & $-3.221 *$ \\
\hline & {$[0.992]$} & {$[0.540]$} & {$[0.420]$} & {$[0.809]$} & [1.663] \\
\hline \multirow[t]{2}{*}{ Pre-issuance Years * High-R\&D Dummy } & $-2.387 * * *$ & $-1.561 * *$ & -0.440 & $-2.209 * * *$ & $-2.224 * *$ \\
\hline & {$[0.820]$} & {$[0.771]$} & {$[0.388]$} & {$[0.794]$} & {$[1.058]$} \\
\hline \multirow[t]{2}{*}{ Issuance Year * High-R\&D Dummy } & $1.085 *$ & $-1.439 * * *$ & $-1.063 * * *$ & $-2.443 * * *$ & 0.473 \\
\hline & {$[0.623]$} & {$[0.503]$} & {$[0.395]$} & {$[0.689]$} & [1.362] \\
\hline \multirow[t]{2}{*}{ Post-issuance Years * High-R\&D Dummy } & -1.668 & -0.584 & $-1.218 *$ & -1.285 & -0.293 \\
\hline & [1.201] & {$[0.568]$} & {$[0.615]$} & {$[1.008]$} & {$[1.340]$} \\
\hline No. of Observations & 637,392 & 603,071 & 438,409 & 616,344 & 422,973 \\
\hline R-squared & 0.199 & 0.196 & 0.197 & 0.176 & 0.139 \\
\hline
\end{tabular}




\section{TABLE 8. COUNTRY FINANCIAL STRUCTURE AND FIRM COMPOSITION}

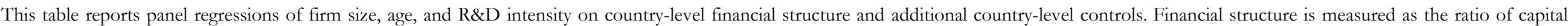

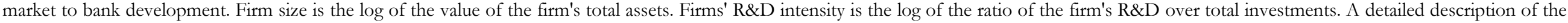

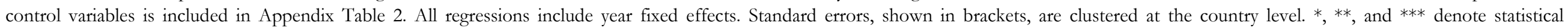
significance at $10 \%, 5 \%$, and $1 \%$, respectively.

\begin{tabular}{|c|c|c|c|c|c|c|c|c|c|}
\hline & \multicolumn{3}{|c|}{$\log ($ Size $)$} & \multicolumn{3}{|c|}{$\log ($ Age $)$} & \multicolumn{3}{|c|}{$\log (\mathbf{R} \& D$ Intensity) } \\
\hline & $(1)$ & (2) & (3) & (4) & (5) & $(6)$ & $(7)$ & (8) & $(9)$ \\
\hline \multirow[t]{2}{*}{ Financial Structure } & $-0.230 * * *$ & $-0.198 *$ & $-0.195 * * *$ & $-0.146 * * *$ & $-0.170 * * *$ & $-0.117 * * *$ & $0.293 * * *$ & $0.206 * * *$ & $0.281 * * *$ \\
\hline & {$[0.070]$} & {$[0.113]$} & {$[0.070]$} & {$[0.037]$} & {$[0.040]$} & {$[0.022]$} & {$[0.071]$} & {$[0.053]$} & {$[0.075]$} \\
\hline \multirow[t]{2}{*}{ Trade } & & -0.001 & & & -0.002 & & & $-0.004 * *$ & \\
\hline & & {$[0.002]$} & & & {$[0.001]$} & & & {$[0.002]$} & \\
\hline \multirow[t]{2}{*}{ Investment } & & 0.025 & & & -0.017 & & & -0.037 & \\
\hline & & {$[0.015]$} & & & {$[0.016]$} & & & {$[0.022]$} & \\
\hline \multirow[t]{2}{*}{ Years of Schooling } & & 0.020 & 0.055 & & 0.044 & $0.056 * *$ & & -0.030 & $0.167 * *$ \\
\hline & & {$[0.173]$} & {$[0.107]$} & & {$[0.050]$} & {$[0.027]$} & & {$[0.198]$} & {$[0.079]$} \\
\hline \multirow[t]{2}{*}{ Log(GDP per capita) } & & & $0.508 * * *$ & & & -0.026 & & & $0.543 * * *$ \\
\hline & & & {$[0.144]$} & & & {$[0.048]$} & & & {$[0.100]$} \\
\hline \multirow[t]{2}{*}{ GDP Growth } & & & -0.107 & & & $-0.117 * * *$ & & & $0.142 * * *$ \\
\hline & & & {$[0.067]$} & & & {$[0.017]$} & & & {$[0.030]$} \\
\hline \multirow[t]{2}{*}{ Government Expenditure } & & & -0.040 & & & $-0.023 *$ & & & 0.096 \\
\hline & & & {$[0.025]$} & & & {$[0.013]$} & & & {$[0.034]$} \\
\hline \multirow[t]{2}{*}{ Inflation Rate } & & & $-0.067 * *$ & & & 0.002 & & & -0.059 \\
\hline & & & {$[0.032]$} & & & {$[0.003]$} & & & {$[0.023]$} \\
\hline \multirow[t]{2}{*}{ Rule of Law } & & & $-1.302 * * *$ & & & -0.097 & & & 0.132 \\
\hline & & & {$[0.328]$} & & & {$[0.091]$} & & & {$[0.174]$} \\
\hline No. of Observations & 543,355 & 543,355 & 424,462 & 321,506 & 321,506 & 224,506 & 173,868 & 173,868 & 142,147 \\
\hline R-squared & 0.051 & 0.056 & 0.068 & 0.069 & 0.081 & 0.129 & 0.078 & 0.108 & 0.196 \\
\hline
\end{tabular}


TABLE 9. THE ROLE OF FINANCIAL STRUCTURE

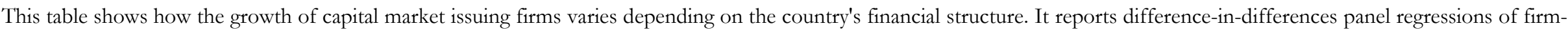

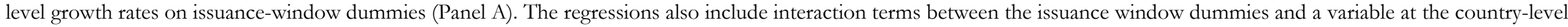

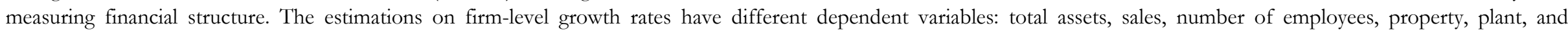

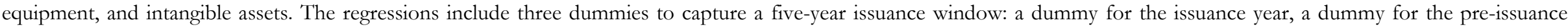

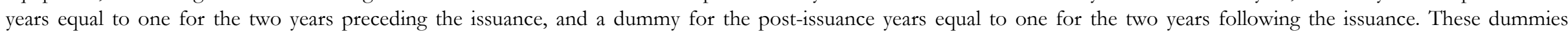

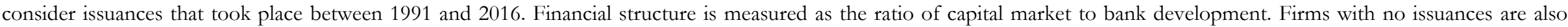

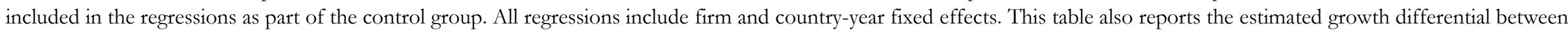

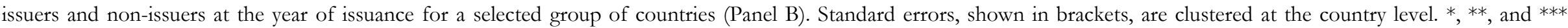
denote statistical significance at $10 \%, 5 \%$, and $1 \%$, respectively.

\section{A. Regression Analysis}

\begin{tabular}{|c|c|c|c|c|c|}
\hline & Total Assets & Sales & $\begin{array}{l}\text { Number of } \\
\text { Employees }\end{array}$ & $\begin{array}{l}\text { Property, Plant, } \\
\text { and Equipment }\end{array}$ & Intangible Assets \\
\hline \multirow[t]{2}{*}{ Pre-issuance Years } & -0.067 & $3.583 * *$ & $1.878 * *$ & $3.239 * *$ & $3.879 * * *$ \\
\hline & [1.106] & {$[1.491]$} & {$[0.757]$} & {$[1.210]$} & [1.283] \\
\hline \multirow[t]{2}{*}{ Issuance Year } & $15.827 * * *$ & 1.557 & 2.378 & $5.359 * *$ & $7.503 * *$ \\
\hline & {$[5.165]$} & [1.383] & [1.590] & [2.269] & {$[3.223]$} \\
\hline \multirow[t]{2}{*}{ Post-issuance Years } & 0.168 & 1.782 & $1.689 * * *$ & $3.930 * *$ & $4.548 *$ \\
\hline & [2.241] & {$[1.520]$} & {$[0.587]$} & {$[1.573]$} & [2.359] \\
\hline \multirow[t]{2}{*}{ Pre-issuance Years * Financial Structure } & $2.645 * * *$ & $0.795 *$ & $0.947 * * *$ & $1.376 * * *$ & $1.472 * * *$ \\
\hline & {$[0.328]$} & {$[0.408]$} & {$[0.171]$} & {$[0.252]$} & {$[0.333]$} \\
\hline \multirow[t]{2}{*}{ Issuance Year * Financial Structure } & 1.164 & $2.064 * * *$ & $1.723 * * *$ & $2.286 * * *$ & $2.205 * * *$ \\
\hline & {$[1.356]$} & {$[0.386]$} & {$[0.392]$} & {$[0.475]$} & {$[0.749]$} \\
\hline \multirow[t]{2}{*}{ Post-issuance Years * Financial Structure } & $-1.465 *$ & 0.003 & $0.224 * *$ & -0.174 & -0.084 \\
\hline & {$[0.729]$} & {$[0.321]$} & {$[0.102]$} & {$[0.411]$} & {$[0.644]$} \\
\hline No. of Observations & 485,191 & 466,432 & 362,655 & 470,812 & 331,988 \\
\hline R-squared & 0.247 & 0.215 & 0.216 & 0.209 & 0.150 \\
\hline
\end{tabular}

B. Estimated Growth Differential between Issuers and Non-issuers for Selected Countries, Year of Issuance

\begin{tabular}{|c|c|c|c|c|c|}
\hline United States (Benchmark) & 20.576 & 9.978 & 9.407 & 14.685 & 16.499 \\
\hline \multicolumn{6}{|l|}{ Market-based } \\
\hline Chile & 18.190 & 5.748 & 5.876 & 10.001 & 11.980 \\
\hline Singapore & 18.222 & 5.804 & 5.923 & 10.063 & 12.040 \\
\hline \multicolumn{6}{|l|}{ Bank-based } \\
\hline China & 16.405 & 2.582 & 3.234 & 6.494 & 8.598 \\
\hline Germany & 16.778 & 3.244 & 3.786 & 7.227 & 9.305 \\
\hline
\end{tabular}




\section{TABLE 10. PROBABILITY OF ISSUANCE AND INDUSTRY PRICES}

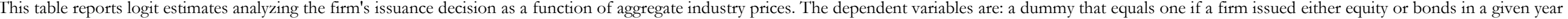

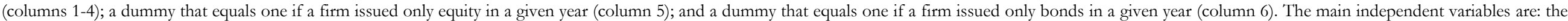

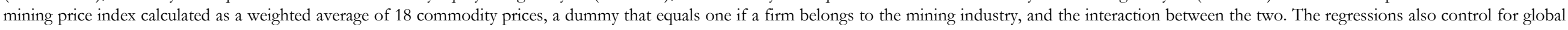

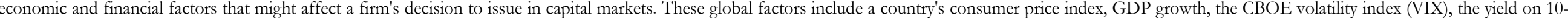

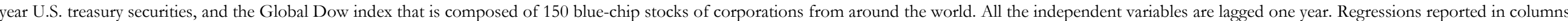

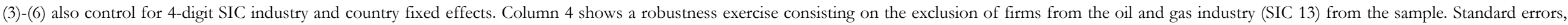
shown in brackets, are clustered at the country level. ${ }^{*}, *$, and $* * *$ denote statistical significance at $10 \%, 5 \%$, and $1 \%$, respectively.

\begin{tabular}{|c|c|c|c|c|c|c|}
\hline & \multicolumn{4}{|c|}{$\begin{array}{c}\text { Capital Market } \\
\text { Issuance Dummy }\end{array}$} & \multirow{2}{*}{$\begin{array}{c}\begin{array}{c}\text { Equity } \\
\text { Issuance Dummy }\end{array} \\
(5)\end{array}$} & \multirow{2}{*}{$\begin{array}{c}\text { Bond } \\
\text { Issuance Dummy }\end{array}$} \\
\hline & $(1)$ & $(2)$ & (3) & (4) & & \\
\hline \multirow[t]{2}{*}{ Mining Price Index } & 0.003 & 0.001 & 0.001 & 0.000 & 0.001 & -0.002 \\
\hline & {$[0.002]$} & {$[0.001]$} & {$[0.001]$} & {$[0.001]$} & {$[0.002]$} & {$[0.001]$} \\
\hline \multirow[t]{2}{*}{ Mining Dummy } & -0.225 & -0.226 & -0.300 & -0.569 & -0.028 & $-1.804 * *$ \\
\hline & {$[0.180]$} & {$[0.169]$} & {$[0.269]$} & {$[0.348]$} & {$[0.445]$} & {$[0.721]$} \\
\hline \multirow[t]{2}{*}{ Mining Price Index * Mining Dummy } & $0.012 * * *$ & $0.012 * * *$ & $0.012 * * *$ & $0.015^{* * *}$ & $0.012 * * *$ & $0.010 * * *$ \\
\hline & {$[0.002]$} & {$[0.002]$} & {$[0.002]$} & {$[0.003]$} & {$[0.002]$} & {$[0.001]$} \\
\hline \multirow[t]{2}{*}{ Consumer Price Index } & & $0.008 * * *$ & 0.008 & 0.007 & 0.004 & 0.013 \\
\hline & & {$[0.003]$} & {$[0.006]$} & {$[0.006]$} & {$[0.006]$} & {$[0.005]$} \\
\hline \multirow[t]{2}{*}{ GDP Growth } & & -0.020 & -0.013 & -0.013 & -0.016 & -0.015 \\
\hline & & {$[0.015]$} & {$[0.021]$} & {$[0.022]$} & {$[0.016]$} & {$[0.029]$} \\
\hline \multirow[t]{2}{*}{ VIX } & & $-0.015 * *$ & $-0.015 * *$ & $-0.016 * *$ & -0.009 & -0.022 \\
\hline & & {$[0.006]$} & {$[0.007]$} & {$[0.007]$} & {$[0.007]$} & {$[0.015]$} \\
\hline \multirow[t]{2}{*}{ U.S. 10 Yr Treasury Constant Maturity Rate } & & -0.016 & -0.027 & -0.032 & -0.022 & -0.006 \\
\hline & & {$[0.042]$} & {$[0.042]$} & {$[0.042]$} & {$[0.043]$} & {$[0.071]$} \\
\hline \multirow[t]{2}{*}{ Global Dow Index } & & -0.001 & -0.001 & -0.001 & -0.001 & \\
\hline & & {$[0.001]$} & {$[0.001]$} & {$[0.001]$} & {$[0.001]$} & \\
\hline \multirow[t]{2}{*}{ Constant } & $-2.560 * * *$ & $-2.415 * * *$ & $-2.375 * * *$ & $-2.235 * * *$ & $-2.943 * * *$ & $-3.810 * * *$ \\
\hline & {$[0.180]$} & {$[0.347]$} & {$[0.686]$} & {$[0.689]$} & {$[1.012]$} & {$[1.002]$} \\
\hline Country Fixed Effects & No & No & Yes & Yes & Yes & Yes \\
\hline Industry Fixed Effects & No & No & Yes & Yes & Yes & Yes \\
\hline No. of Observations & $1,844,175$ & $1,759,357$ & $1,759,285$ & $1,681,611$ & $1,758,637$ & $1,827,278$ \\
\hline
\end{tabular}




\section{APPENDIX FIGURE 1. HETEROGENEITY ACROSS FIRMS, QUARTILE ESTIMATES}

This figure shows the estimated annual growth rate differential between issuers and non-issuers at the year of issuance for each of the four quartiles of the distributions of firm size, age, and R\&D intensity. Growth differentials are measured for five variables, each of which is shown in a different panel: total assets, sales, number of employees, property, plant, and equipment, and intangible assets. The statistics shown in this figure are obtained from the estimation of quantile regressions using the specification described in Table 2 for each quartile of the distribution. The vertical lines show the confidence interval around these estimates at the $95 \%$ statistical confidence level. Firm size is measured as the $\log$ of total assets and $\mathrm{R} \& \mathrm{D}$ intensity as the log of R\&D-to-total investment. Firms are assigned into each quartile based on their median size, age, and R\&D intensity over the sample period.

\section{A. Total Assets}

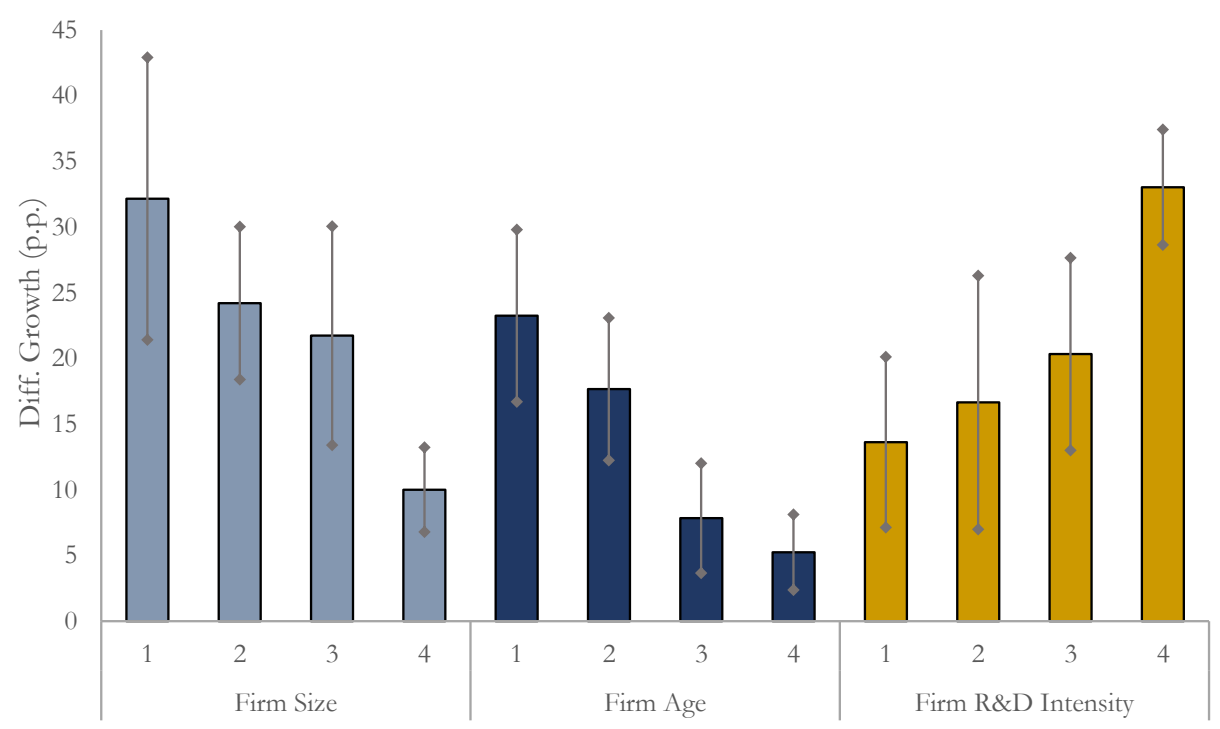

B. Sales

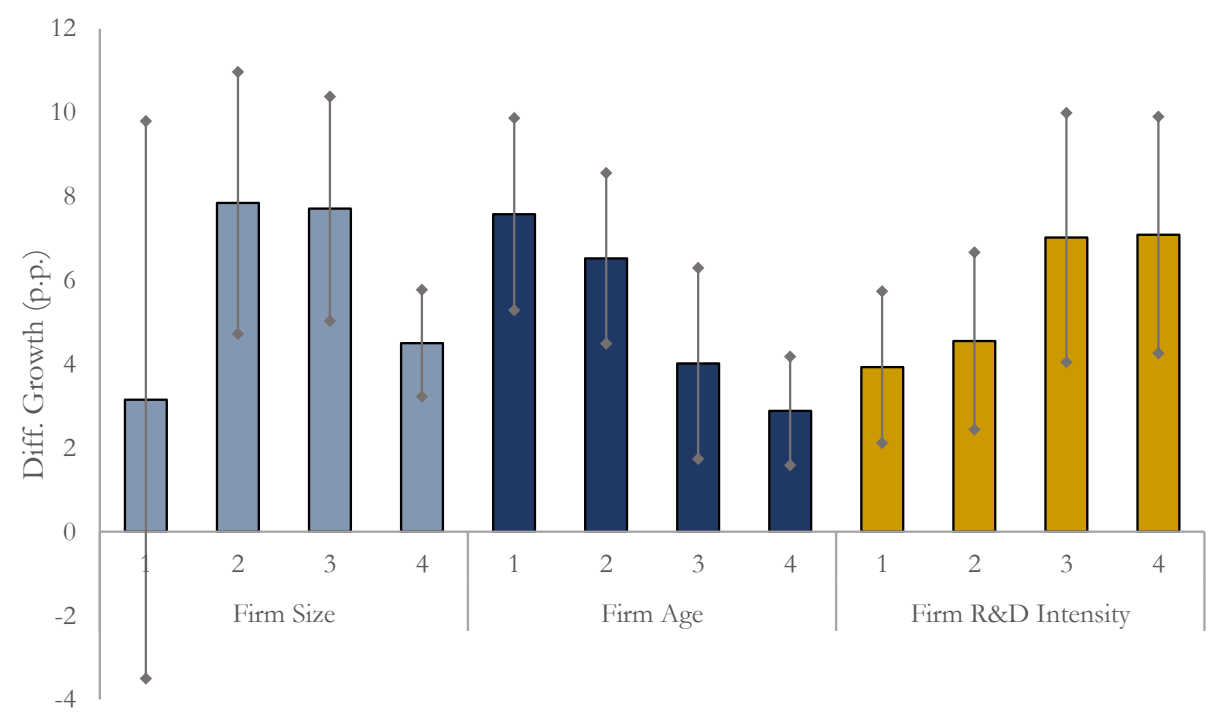

(Continued on next page) 
APPENDIX FIGURE 1. HETEROGENEITY ACROSS FIRMS, QUARTILE ESTIMATES

C. Number of Employees

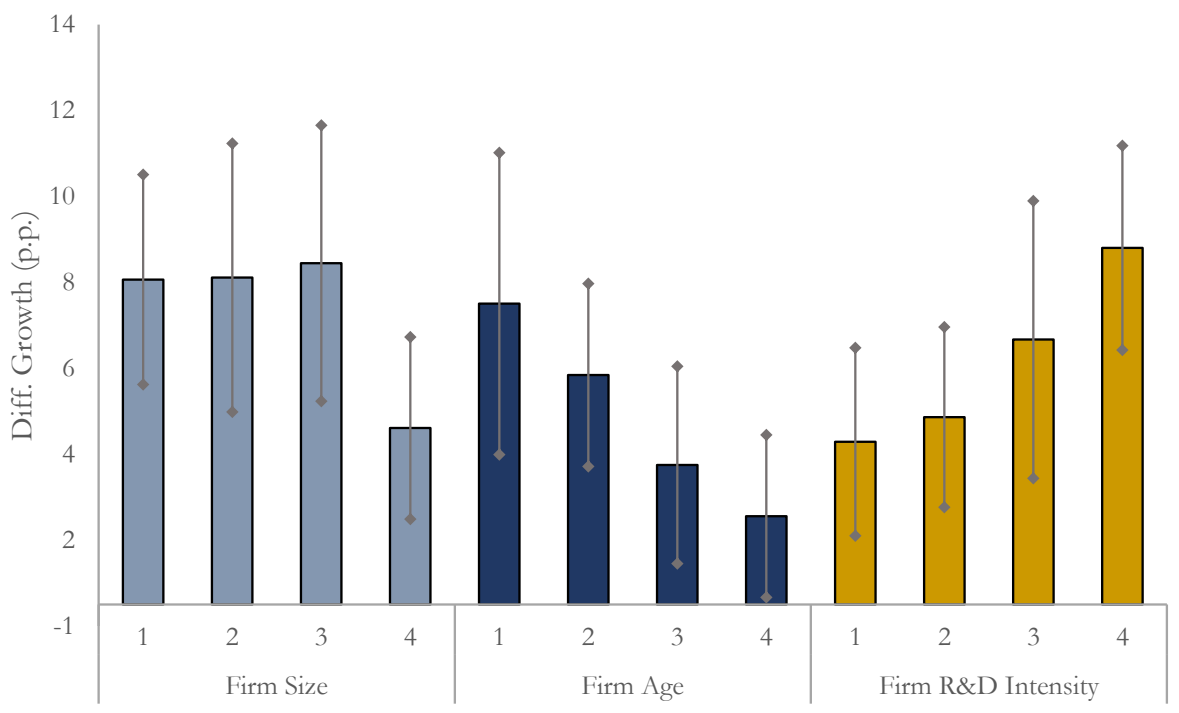

D. Property, Plant, and Equipment

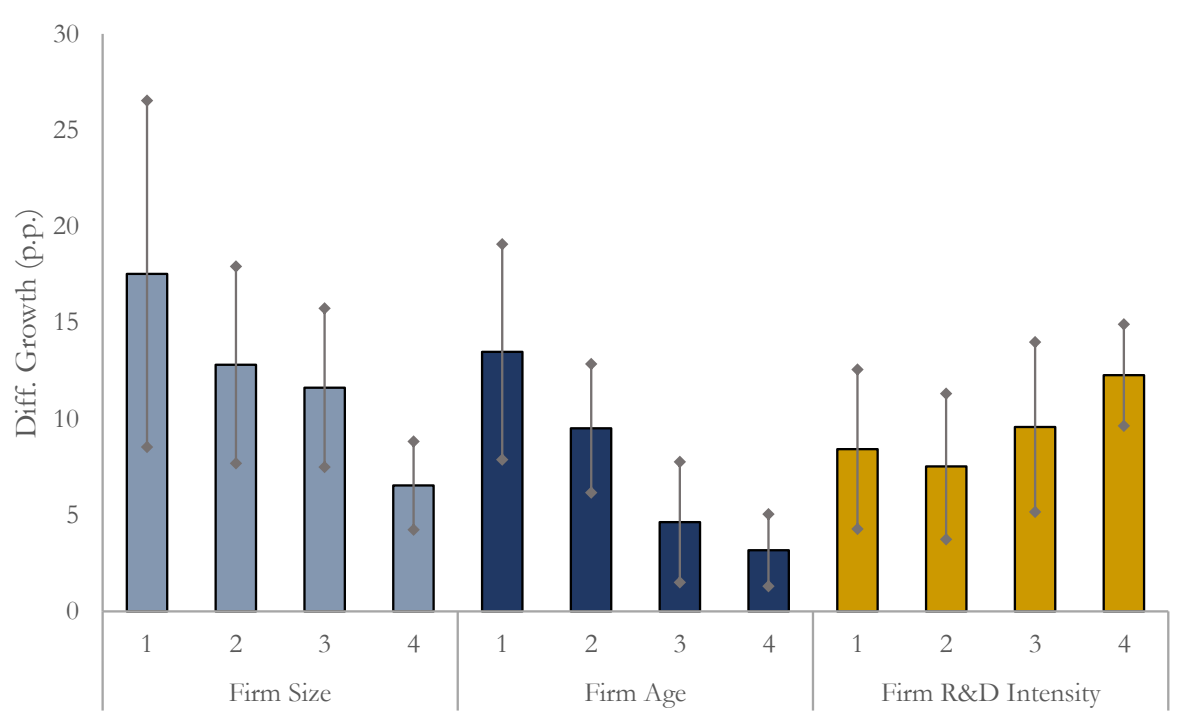

E. Intangible Assets

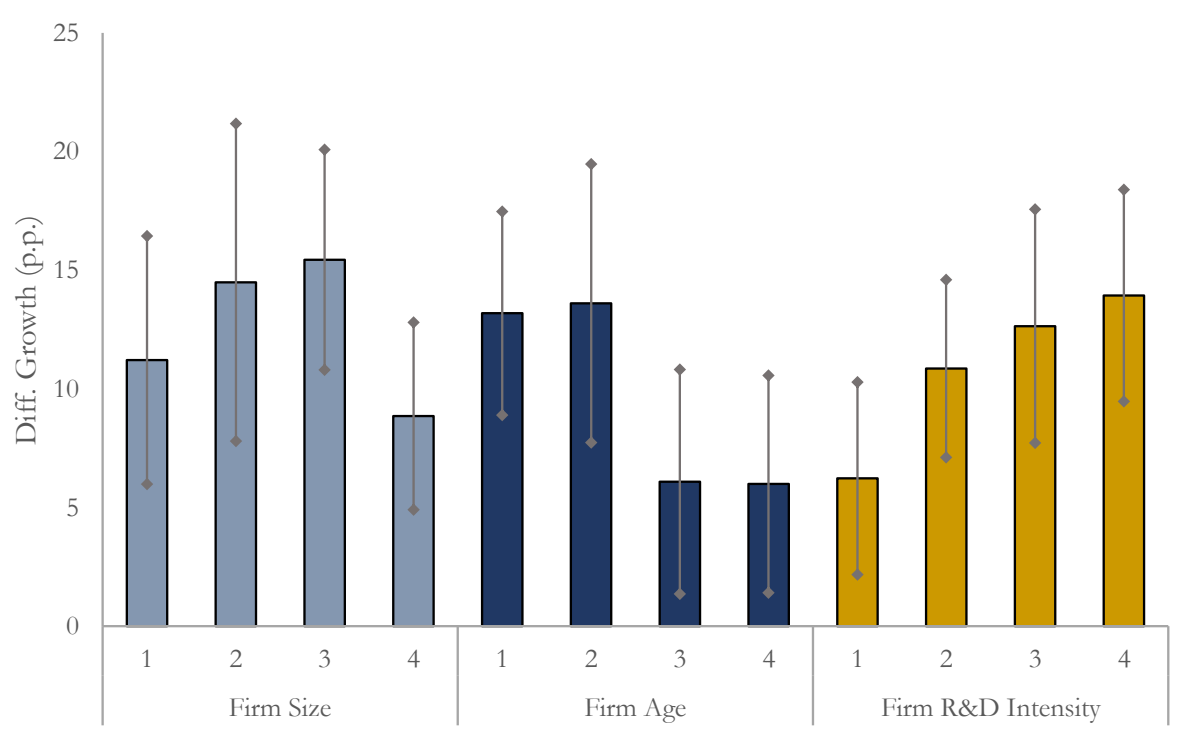


APPENDIX FIGURE 2. FINANCIAL SYSTEM STRUCTURE

This figure shows the ratio of capital market to bank development for each country in the sample. Capital market development is the sum of both equity market capitalization and corporate bond market capitalization. Bank development is measured as private credit by deposit money banks. The reported statistics are calculated as over-time averages between 1991 and 2016.

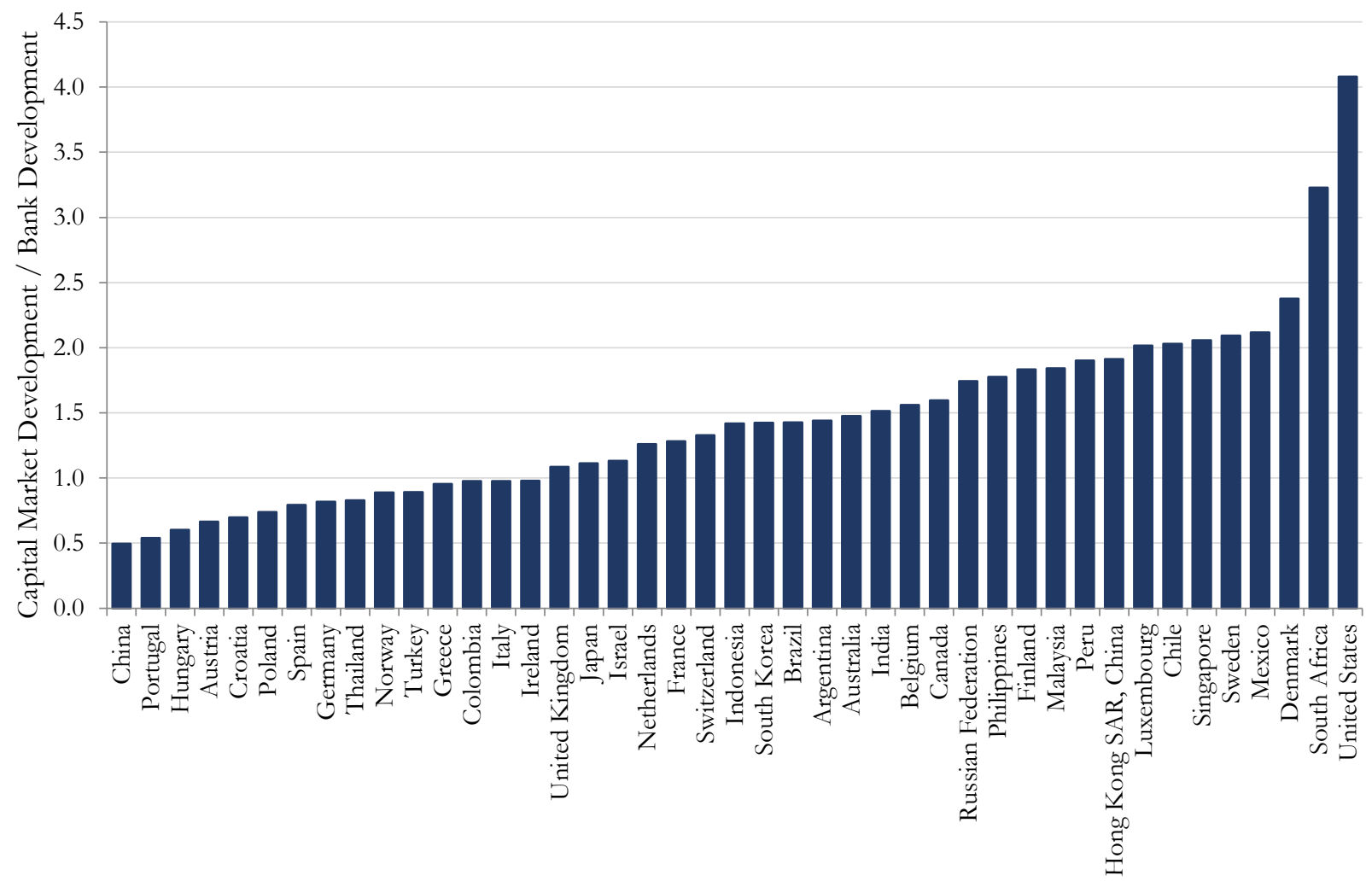


APPENDIX TABLE 1. COUNTRY COVERAGE

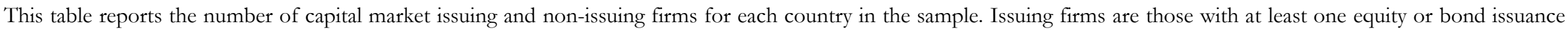
between 1991 and 2016. Non-issuing firms are all other firms in the sample.

\begin{tabular}{|c|c|c|c|c|c|c|c|}
\hline \multirow[b]{2}{*}{ Country } & \multicolumn{3}{|c|}{ Number of Listed Firms } & \multirow[b]{2}{*}{ Country } & \multicolumn{3}{|c|}{ Number of Listed Firms } \\
\hline & Total & Issuers & Non-issuers & & Total & Issuers & Non-issuers \\
\hline Argentina & 127 & 91 & 36 & Morocco & 60 & 37 & 23 \\
\hline Australia & 2,608 & 2,413 & 195 & Netherlands & 352 & 252 & 100 \\
\hline Austria & 162 & 97 & 65 & New Zealand & 224 & 174 & 50 \\
\hline Belgium & 216 & 138 & 78 & Nigeria & 90 & 19 & 71 \\
\hline Brazil & 553 & 357 & 196 & Norway & 427 & 293 & 134 \\
\hline Bulgaria & 210 & 20 & 190 & Oman & 98 & 46 & 52 \\
\hline Canada & 4,275 & 3,821 & 454 & Pakistan & 294 & 111 & 183 \\
\hline Chile & 243 & 157 & 86 & Peru & 161 & 60 & 101 \\
\hline China & 4,462 & 3,961 & 501 & Philippines & 216 & 167 & 49 \\
\hline Colombia & 93 & 49 & 44 & Poland & 566 & 372 & 194 \\
\hline Croatia & 102 & 17 & 85 & Portugal & 122 & 78 & 44 \\
\hline Denmark & 265 & 159 & 106 & Qatar & 26 & 19 & 7 \\
\hline Egypt, Arab Rep. & 170 & 108 & 62 & Romania & 147 & 18 & 129 \\
\hline Finland & 224 & 157 & 67 & Russian Federation & 775 & 208 & 567 \\
\hline France & 1,514 & 1,042 & 472 & Saudi Arabia & 132 & 85 & 47 \\
\hline Germany & 1,308 & 844 & 464 & Singapore & 853 & 762 & 91 \\
\hline Greece & 386 & 203 & 183 & South Africa & 680 & 175 & 505 \\
\hline Hong Kong SAR, China & 1,449 & 1,287 & 162 & Korea, Rep. & 2,254 & 1,994 & 260 \\
\hline Hungary & 61 & 22 & 39 & Spain & 277 & 167 & 110 \\
\hline India & 3,026 & 2,107 & 919 & Sri Lanka & 184 & 79 & 105 \\
\hline Indonesia & 482 & 410 & 72 & Sweden & 866 & 561 & 305 \\
\hline Ireland & 179 & 137 & 42 & Switzerland & 364 & 236 & 128 \\
\hline Israel & 567 & 270 & 297 & Taiwan, China & 2,206 & 1,466 & 740 \\
\hline Italy & 467 & 343 & 124 & Thailand & 678 & 567 & 111 \\
\hline Japan & 4,911 & 4,047 & 864 & Tunisia & 53 & 37 & 16 \\
\hline Jordan & 137 & 62 & 75 & Turkey & 348 & 176 & 172 \\
\hline Kazakhstan & 38 & 10 & 28 & Ukraine & 114 & 10 & 104 \\
\hline Kenya & 43 & 11 & 32 & United Arab Emirates & 66 & 38 & 28 \\
\hline Kuwait & 105 & 42 & 63 & United Kingdom & 3,670 & 2,715 & 955 \\
\hline Lithuania & 40 & 13 & 27 & United States & 15,596 & 10,315 & 5,281 \\
\hline Luxembourg & 80 & 57 & 23 & Venezuela, RB & 28 & 25 & 3 \\
\hline Malaysia & 1,223 & 1,084 & 139 & Vietnam & 787 & 350 & 437 \\
\hline Mexico & 213 & 158 & 55 & & & & \\
\hline
\end{tabular}




\section{APPENDIX TABLE 2. DATA DESCRIPTION}

This table describes the control variables included in the regressions reported in Table 8 and Table 10 .

\begin{tabular}{|c|c|c|}
\hline Variable & Source & Description \\
\hline $\begin{array}{l}\text { Financial } \\
\text { Structure }\end{array}$ & $\begin{array}{l}\text { World Bank Financial } \\
\text { Structure Database }\end{array}$ & $\begin{array}{l}\text { Financial structure is measured by the ratio of capital market development to bank development. Capital market development is the sum of } \\
\text { stock market capitalization and private bond market capitalization. Bank development is measured as deposit money bank credit to the private } \\
\text { sector. }\end{array}$ \\
\hline $\begin{array}{l}\text { Government } \\
\text { Expenditure }\end{array}$ & $\begin{array}{l}\text { World Bank Development } \\
\text { Indicators }\end{array}$ & $\begin{array}{l}\text { General government final consumption expenditure as a share of GDP. It includes all government current expenditures for purchases of goods } \\
\text { and services (including compensation of employees). It also includes most expenditures on national defense and security, but excludes } \\
\text { government military expenditures that are part of government capital formation. }\end{array}$ \\
\hline $\begin{array}{l}\text { GDP per } \\
\text { Capita }\end{array}$ & $\begin{array}{l}\text { IMF World Economic } \\
\text { Outlook Database }\end{array}$ & GDP expressed in U.S. dollars per person. Adjusted for inflation using 2011 prices. \\
\hline GDP Growth & $\begin{array}{l}\text { IMF World Economic } \\
\text { Outlook Database }\end{array}$ & $\begin{array}{l}\text { Average growth rate of GDP during the sample period. Prior to the calculation of the growth rate, the GDP has been adjusted for inflation } \\
\text { using } 2011 \text { prices. }\end{array}$ \\
\hline Inflation Rate & $\begin{array}{l}\text { World Bank Development } \\
\text { Indicators }\end{array}$ & $\begin{array}{l}\text { Inflation as measured by the consumer price index. It reflects the annual percentage change in the cost to the average consumer of acquiring a } \\
\text { basket of goods and services that may be fixed or changed at specified intervals, such as yearly. }\end{array}$ \\
\hline Investment & $\begin{array}{l}\text { World Bank Development } \\
\text { Indicators }\end{array}$ & $\begin{array}{l}\text { Gross fixed capital formation as a share of GDP. It includes land improvements (fences, ditches, drains); plant, machinery, and equipment } \\
\text { purchases; and the construction of roads, railways, and the like, including schools, offices, hospitals, private residential dwellings, and } \\
\text { commercial and industrial buildings. }\end{array}$ \\
\hline Rule of Law & $\begin{array}{l}\text { Worldwide Governance } \\
\text { Indicators }\end{array}$ & $\begin{array}{l}\text { Rule of law captures perceptions of the extent to which agents have confidence in and abide by the rules of society, and in particular the quality } \\
\text { of contract enforcement, property rights, the police, and the courts, as well as the likelihood of crime and violence. This variable gives the } \\
\text { country's score on the aggregate indicator, in units of a standard normal distribution. It ranges from approximately }-2.5 \text { to } 2.5 \text {, where higher is } \\
\text { better. }\end{array}$ \\
\hline Trade & $\begin{array}{l}\text { World Bank Development } \\
\text { Indicators }\end{array}$ & Trade is the sum of exports and imports of goods and services measured as a share of GDP. \\
\hline $\begin{array}{l}\text { Years of } \\
\text { Schooling }\end{array}$ & $\begin{array}{l}\text { World Bank Development } \\
\text { Indicators }\end{array}$ & Average years of secondary schooling attained. \\
\hline $\begin{array}{l}\text { Mining Price } \\
\text { Index }\end{array}$ & $\begin{array}{l}\text { World Bank Commodity } \\
\text { Price Data, IMF Primary } \\
\text { Commodity Price Data }\end{array}$ & $\begin{array}{l}\text { The mining price index is constructed as a weighted average of } 18 \text { commodity prices: iron, copper, zinc, lead, gold, silver, nickel, cobalt, } \\
\text { uranium, aluminum, tin, platinum, palladium, coal, oil, gas, potassium chloride, and phosphate rock. The weights are calculated based on the } \\
\text { commodity's global import share over the period 2014-16. Prices are normalized to } 100 \text { at year } 2010 \text {. }\end{array}$ \\
\hline VIX & $\begin{array}{l}\text { Federal Reserve Bank of St. } \\
\text { Louis }\end{array}$ & $\begin{array}{l}\text { Chicago Board Options Exchange market volatility index. The VIX index is a measure of 30-day expected volatility of the U.S. stock market, } \\
\text { derived from real-time, mid-quote prices of S\&P } 500 \text { Index call and put options. }\end{array}$ \\
\hline $\begin{array}{l}\text { Global Dow } \\
\text { Index }\end{array}$ & Refinitiv & $\begin{array}{l}\text { The Global Dow is a } 150 \text {-stock index of leading blue chip companies from around the world. The index includes companies with a long history } \\
\text { of success and a wide following among investors. The index is equal-weighted and includes companies from developed and emerging } \\
\text { economies. }\end{array}$ \\
\hline $\begin{array}{l}\text { U.S. } 10 \text { Yr } \\
\text { Treasury } \\
\text { Constant } \\
\text { Maturity Rate }\end{array}$ & $\begin{array}{l}\text { Federal Reserve Bank of } \\
\text { St. Louis }\end{array}$ & $\begin{array}{l}\text { Index based on the average yield of a range of U.S. Treasury securities with } 10 \text {-year maturity. Constant maturity yields are used as a reference } \\
\text { for pricing debt securities issued by entities such as corporations and institutions (for example, corporate bonds). }\end{array}$ \\
\hline
\end{tabular}




\section{APPENDIX TABLE 3. CAPITAL MARKET FINANCING AND FIRM GROWTH. ONLY ISSUING FIRMS}

This table reports difference-in-differences panel regressions of firm-level growth rates on issuance-window dummies. Contrary to Table 2 , we restrict the analysis to firms that issued either equity or bonds at least once during the period 1991-2016. The estimations on firm-level growth rates have different dependent variables: total assets, sales, number of employees, property, plant, and equipment, and intangible assets. The issuance window dummies capture a five-year window around capital raising issuances that took place between 1991 and 2016. Three dummies are included in the regressions: a dummy for the issuance year, a dummy for the pre-issuance years equal to one for the two years preceding the issuance, and a dummy for the post-issuance years equal to one for the two years following the issuance. The table considers three different definitions of issuing firms: both equity and bond issuers (capital market issuers) (Panel A), only equity issuers (Panel B), and only bond issuers (Panel C). All regressions include firm and country-year fixed effects. The table reports Wald tests on the differences between the coefficients of the pre-issuance and issuance dummies. The table also reports the average growth of all firms (both issuers and non-issuers) over the entire sample period. Standard errors, shown in brackets, are clustered at the country level. $*, * *$, and $* * *$ denote statistical significance at $10 \%, 5 \%$, and $1 \%$, respectively.

A. Capital Market Issuance

\begin{tabular}{|c|c|c|c|c|c|}
\hline & Total Assets & Sales & $\begin{array}{l}\text { Number of } \\
\text { Employees }\end{array}$ & $\begin{array}{l}\text { Property, Plant, } \\
\text { and Equipment }\end{array}$ & Intangible Assets \\
\hline \multirow[t]{2}{*}{ Pre Issuance Years } & 5.376 *** & $5.356 * * *$ & $3.863 * * *$ & $6.384 * * *$ & $6.731 * * *$ \\
\hline & {$[1.186]$} & {$[0.637]$} & {$[0.636]$} & {$[0.983]$} & {$[0.860]$} \\
\hline \multirow[t]{2}{*}{ Issuance Year } & $19.232 * * *$ & $5.625 * * *$ & $5.923 * * *$ & $10.532 * * *$ & $11.438 * * *$ \\
\hline & {$[2.625]$} & {$[0.955]$} & {$[1.160]$} & {$[1.802]$} & {$[1.722]$} \\
\hline \multirow[t]{2}{*}{ Post Issuance Years } & $-2.938 *$ & $1.693 * *$ & $1.990 * * *$ & $3.232 * * *$ & $3.809 * * *$ \\
\hline & {$[1.664]$} & {$[0.809]$} & {$[0.358]$} & {$[0.832]$} & {$[1.190]$} \\
\hline Firm Fixed Effects & Yes & Yes & Yes & Yes & Yes \\
\hline Country-Year Fixed Effects & Yes & Yes & Yes & Yes & Yes \\
\hline No. of Observations & 498,957 & 470,875 & 348,938 & 484,355 & 340,895 \\
\hline R-squared & 0.217 & 0.190 & 0.197 & 0.173 & 0.138 \\
\hline \multicolumn{6}{|l|}{ Wald Test: } \\
\hline Issuance vs. Pre Issuance Years & $13.856 * * *$ & 0.268 & $2.060 * * *$ & $4.148 * * *$ & $4.708 * * *$ \\
\hline
\end{tabular}

\begin{tabular}{|c|c|c|c|c|c|}
\hline \multicolumn{6}{|c|}{ B. Equity Issuance } \\
\hline & Total Assets & Sales & $\begin{array}{l}\text { Number of } \\
\text { Employees } \\
\end{array}$ & $\begin{array}{l}\text { Property, Plant, } \\
\text { and Equipment }\end{array}$ & Intangible Assets \\
\hline \multirow[t]{2}{*}{ Pre Issuance Years } & $5.647^{* * *}$ & $5.645 * * *$ & $3.833 * * *$ & $6.661 * * *$ & $6.941 * * *$ \\
\hline & {$[1.275]$} & {$[0.715]$} & {$[0.544]$} & {$[1.008]$} & {$[0.929]$} \\
\hline \multirow[t]{2}{*}{ Issuance Year } & $21.629 * * *$ & $6.359 * * *$ & $6.550 * * *$ & $11.556 * * *$ & $12.027 * * *$ \\
\hline & {$[2.806]$} & [1.129] & {$[1.178]$} & {$[1.912]$} & {$[1.681]$} \\
\hline \multirow[t]{2}{*}{ Post Issuance Years } & -2.032 & $2.674 * * *$ & $2.690 * * *$ & $4.414 * * *$ & $5.702 * * *$ \\
\hline & {$[1.624]$} & {$[0.837]$} & {$[0.469]$} & {$[0.908]$} & {$[1.279]$} \\
\hline Firm Fixed Effects & Yes & Yes & Yes & Yes & Yes \\
\hline Country-Year Fixed Effects & Yes & Yes & Yes & Yes & Yes \\
\hline No. of Observations & 498,957 & 470,875 & 348,938 & 484,355 & 340,895 \\
\hline R-squared & 0.217 & 0.190 & 0.196 & 0.173 & 0.138 \\
\hline \multicolumn{6}{|l|}{ Wald Test: } \\
\hline Issuance vs. Pre Issuance Years & $15.981 * * *$ & 0.713 & $2.717 * * *$ & $4.896 * * *$ & $5.087 * * *$ \\
\hline \multicolumn{6}{|c|}{ C. Bond Issuance } \\
\hline \multirow{3}{*}{ Pre Issuance Years } & Total Assets & Sales & $\begin{array}{l}\text { Number of } \\
\text { Employees }\end{array}$ & $\begin{array}{l}\text { Property, Plant, } \\
\text { and Equipment }\end{array}$ & Intangible Assets \\
\hline & $3.761 * * *$ & $2.802 * * *$ & $2.689 * * *$ & $4.245^{* * *}$ & 4.606 *** \\
\hline & {$[0.522]$} & {$[0.281]$} & {$[0.584]$} & [0.609] & {$[0.636]$} \\
\hline \multirow[t]{2}{*}{ Issuance Year } & $7.732 * * *$ & $3.007 * * *$ & $3.634 * * *$ & $5.472 * * *$ & $8.637 * * *$ \\
\hline & {$[1.618]$} & {$[0.621]$} & {$[1.023]$} & [1.022] & {$[2.196]$} \\
\hline \multirow[t]{2}{*}{ Post Issuance Years } & $-3.574 * * *$ & -0.881 & -0.722 & $-2.019 * *$ & $-3.247 * *$ \\
\hline & {$[1.277]$} & {$[0.555]$} & {$[0.561]$} & {$[0.950]$} & {$[1.372]$} \\
\hline Firm Fixed Effects & Yes & Yes & Yes & Yes & Yes \\
\hline Country-Year Fixed Effects & Yes & Yes & Yes & Yes & Yes \\
\hline No. of Observations & 498,957 & 470,875 & 348,938 & 484,355 & 340,895 \\
\hline R-squared & 0.196 & 0.187 & 0.191 & 0.168 & 0.136 \\
\hline \multicolumn{6}{|l|}{ Wald Test: } \\
\hline Issuance vs. Pre Issuance Years & $3.971 * * *$ & 0.205 & 0.945 & $1.227 * *$ & $4.031 * *$ \\
\hline
\end{tabular}

